\title{
WestVirginiaUniversity
}

THE RESEARCH REPOSITORY @ WVU

Graduate Theses, Dissertations, and Problem Reports

2007

\section{Factors that influence an individual's decision to teach agricultural education}

Lee Ann Hall

West Virginia University

Follow this and additional works at: https://researchrepository.wvu.edu/etd

\section{Recommended Citation}

Hall, Lee Ann, "Factors that influence an individual's decision to teach agricultural education" (2007). Graduate Theses, Dissertations, and Problem Reports. 2533.

https://researchrepository.wvu.edu/etd/2533

This Thesis is protected by copyright and/or related rights. It has been brought to you by the The Research Repository @ WVU with permission from the rights-holder(s). You are free to use this Thesis in any way that is permitted by the copyright and related rights legislation that applies to your use. For other uses you must obtain permission from the rights-holder(s) directly, unless additional rights are indicated by a Creative Commons license in the record and/ or on the work itself. This Thesis has been accepted for inclusion in WVU Graduate Theses, Dissertations, and Problem Reports collection by an authorized administrator of The Research Repository @ WVU. For more information, please contact researchrepository@mail.wvu.edu. 


\title{
Factors that Influence an Individual's Decision \\ to Teach Agricultural Education
}

\section{Lee Ann Hall}

Thesis submitted to the Davis College of Agriculture, Forestry, and Consumer Sciences at West Virginia University in partial fulfillment of the requirements

for the degree of

\author{
Master of Science \\ in \\ Agricultural and Extension Education
}

Harry N. Boone, Jr., Ph.D., Chair

Deborah A. Boone, Ph.D.

Stacy A. Gartin, Ph.D.

Division of Resource Management

\section{Morgantown, WV}

2007

Keywords: Agricultural Education, Student Teaching, 4-H, FFA, Agriculture, Education, Influence 


\author{
ABSTRACT \\ Factors that Influence an Individual's Decision \\ to Teach Agricultural Education
}

Lee Ann Hall

The purpose of this study was to determine the factors that influence an individual's decision to teach agricultural education. A descriptive research design, in the form of a census survey, was used to collect data for this study. The population included individuals who completed their student teaching from 2002-2005 while attending one of five universities in the eastern United States. The five most influential factors identified by the respondents included (in order of influence): their agriculture teacher, agricultural background, FFA involvement, high school agricultural program involvement, and family. Individuals who did not teach agriculture made their decision based on the following reasons: student teaching experience, demands of the job, low salary, no teaching jobs in the area, and time requirements. Respondents who had left teaching cited a lack of administrative support, low salary, time requirements, no other available jobs in area, unsuccessful as a teacher, and too many demands other than teaching. 
This thesis is dedicated to the individuals who dedicate their life's work to the agricultural education profession and to the agricultural education teachers who make a difference in the lives of young people everyday. 


\section{ACKNOWLEDGEMENTS}

Behind the completion of every thesis exists people who contributed to the success of the research. I appreciate the efforts of everyone involved and would like to especially thank the following individuals for their influence on my success:

Mom and Dad who supported my decision to continue my education;

Dr. Phil Fravel, Doris Smith, Dr. Rick Rudd, Dr. Jim Flowers, Dr. Dennis Scanlon, and Cathie Graham for securing addresses for my population;

Alice Compton who spent time copying my instrument and preparing other elements of my survey mailings;

Dr. Deborah Boone and Dr. Stacy Gartin for serving on my graduate committee;

Dr. Harry Boone for serving as my graduate advisor/committee chair, providing me the opportunity to gain more professional experience by teaching AGEE 101, being available to answer my questions, exchanging teaching philosophies and ideals for agricultural education, and serving as a professional role model for agricultural education;

Mr. Steve Tennant for serving as my cooperating teacher during student teaching and supporting my career in agricultural education; and

Mr. Leon Ammons, my high school agricultural teacher, who greatly influenced my passion for agricultural education and the FFA and is the reason I chose to teach agriculture. 


\section{TABLE OF CONTENTS}

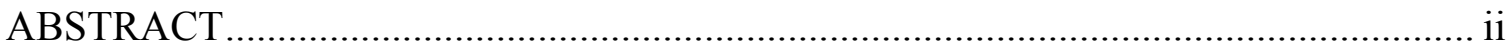

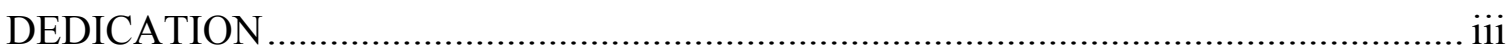

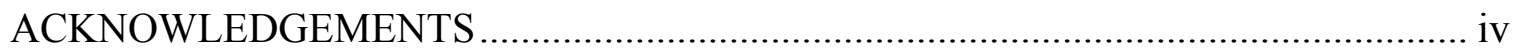

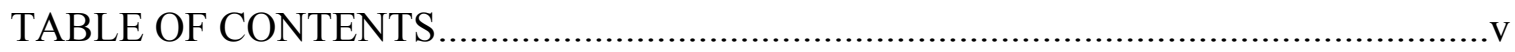

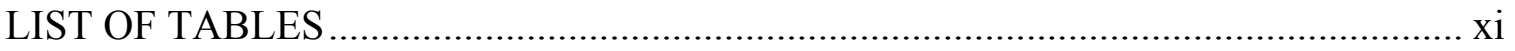

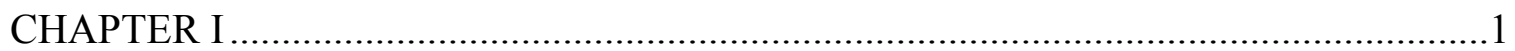

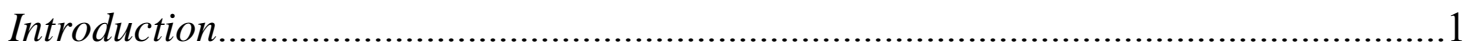

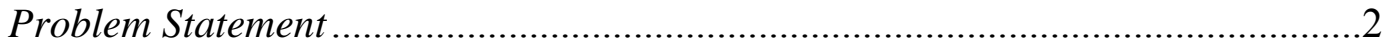

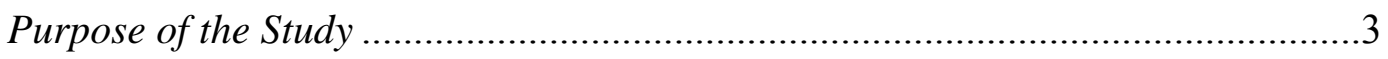

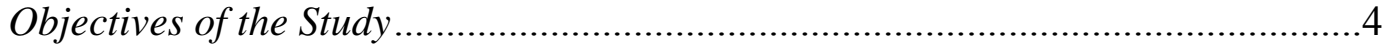

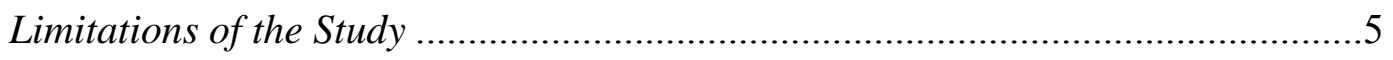

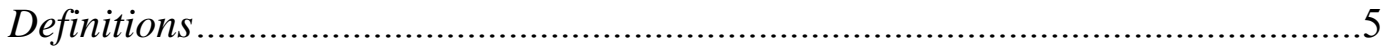

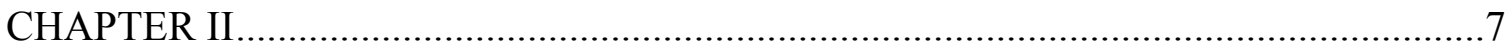

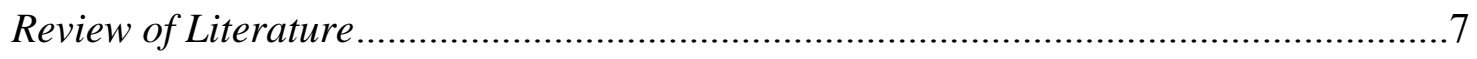

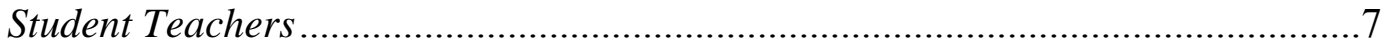

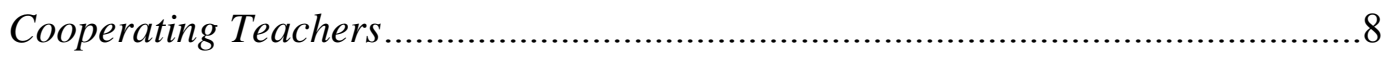

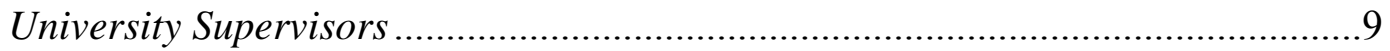

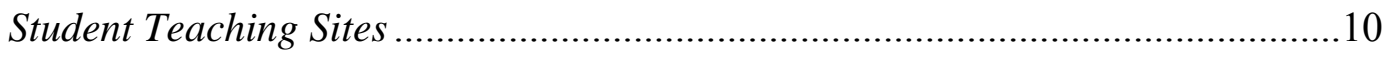

Supervised Agricultural Experience ….........................................................11

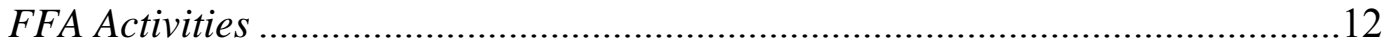

Background in Agricultural Youth Organizations (FFA and 4-H)......................12

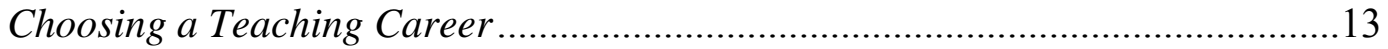




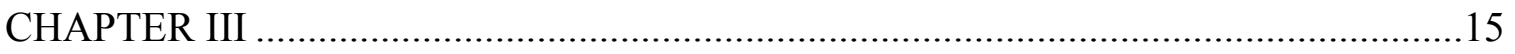

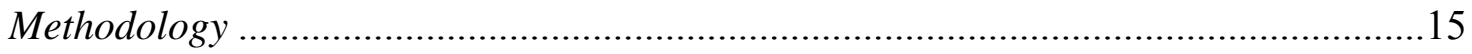

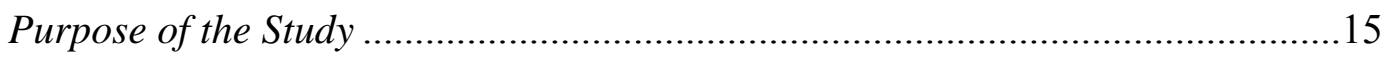

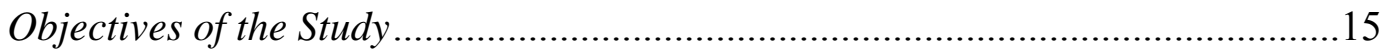

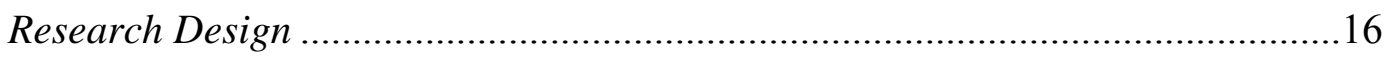

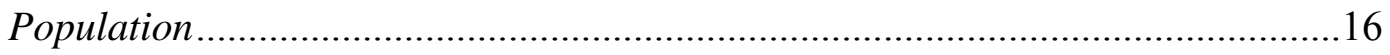

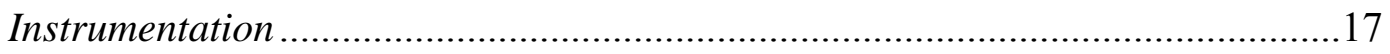

Data Collection Procedures .......................................................................18

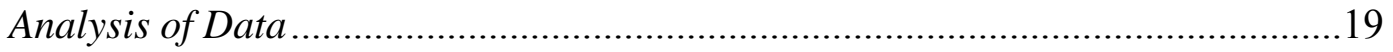

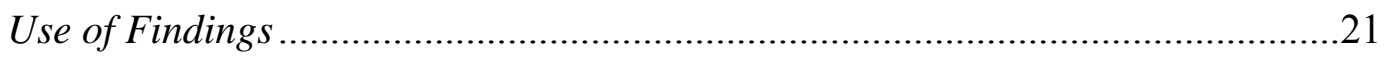

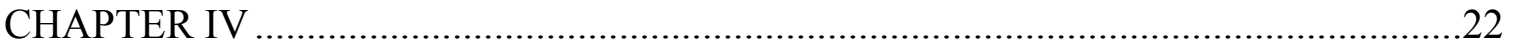

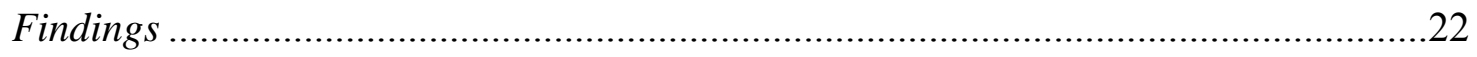

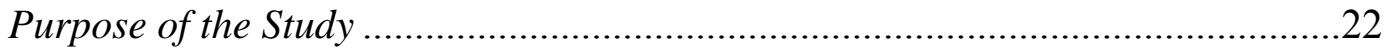

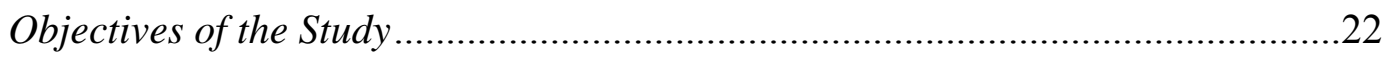

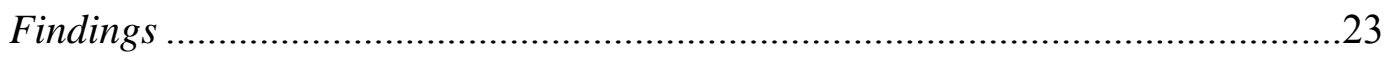

Demographic Characteristics of Respondents...................................................23

Status of Teacher Certification in Agricultural Education......................................25

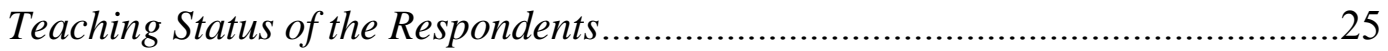

Factors Involved in Student Teaching Site Selection...........................................26

Role of Cooperating Teachers during Student Teaching.......................................33

Role of the University Supervisors during Student Teaching .................................38

School and Community Support during Student Teaching ...................................42

Classroom and Laboratory Experiences during Student Teaching.......................44 
Role with FFA Activities during Student Teaching .........................................46

Stages of Participants’ Decision to Teach Agriculture .......................................46

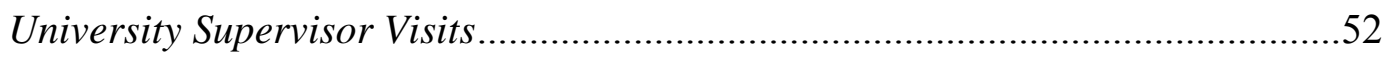

Number of SAE Visits Conducted by the Student Teacher during Student

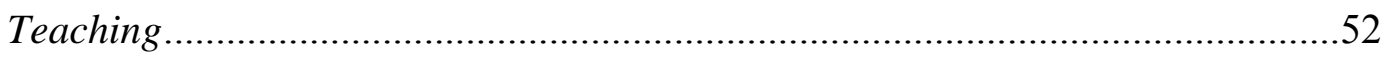

Membership in the National FFA Organization ..............................................53

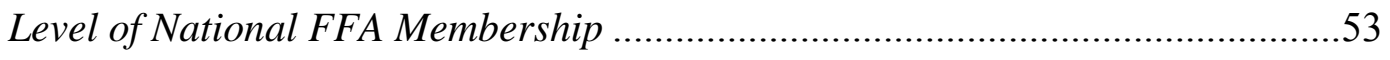

Number of Years of Active FFA Membership ...................................................54

Highest Degree in the National FFA Organization Earned by Individuals who had Completed a Student Teaching Experience.........................................55

Types of Supervised Agricultural Experience Programs (SAE) Conducted by Individuals who had Completed a Student Teaching Experience .....................56

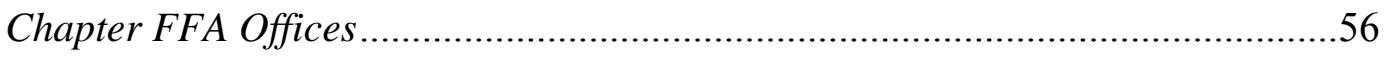

National and State FFA Offices Held by Individuals who Completed a

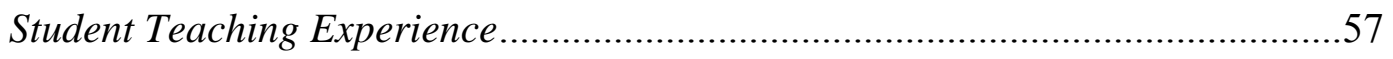

Participation in Leadership Conferences ......................................................58

Participation in FFA Career Development Events (CDE) during Years of

FFA Membership by Individuals who Completed a Student Teaching

Experience.

Participation in FFA Activities during Years of FFA Membership by

Individuals who Completed a Student Teaching Experience. 
Highest Level of FFA Proficiency Awards Earned during Years of FFA

Membership by Individuals who Completed a Student Teaching

Experience

4-H Membership of Individuals who Completed a Student Teaching

Experience

Years of 4-H Participation of Individuals who Completed a Student

Teaching Experience.

Participation in 4-H Projects by Individuals who Completed a Student

Teaching Experience.

4-H Project Areas Completed by Individuals who Completed a Student

Teaching Experience.

4-H Club Offices Held by Individuals who completed a Student Teaching

Experience

Participation in 4-H Activities by Individuals who Completed a Student

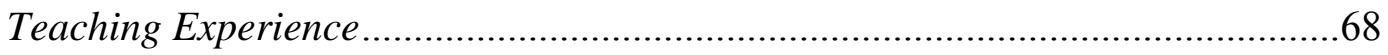

Participants' Comments.............................................................................

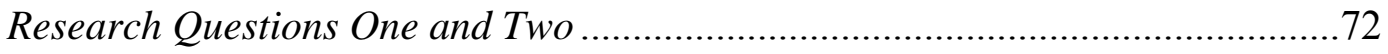

Research Question Three ..............................................................................90

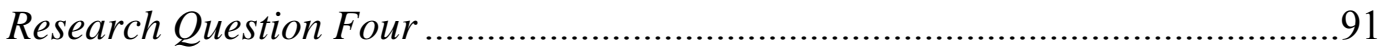

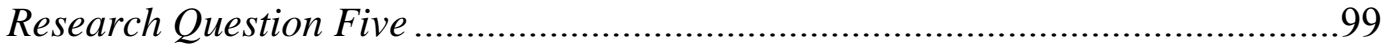

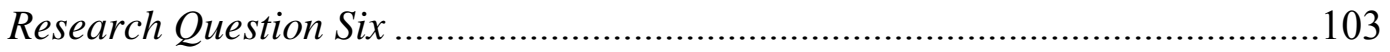

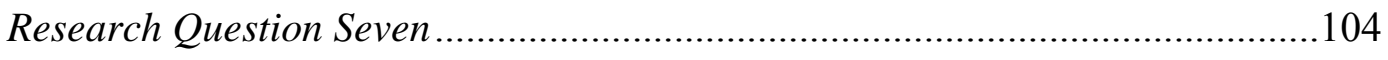

Research Question Eight..............................................................................107 
Research Question Nine .............................................................................108

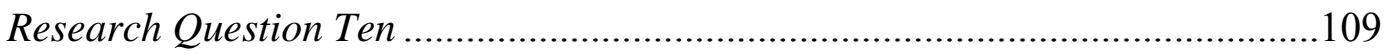

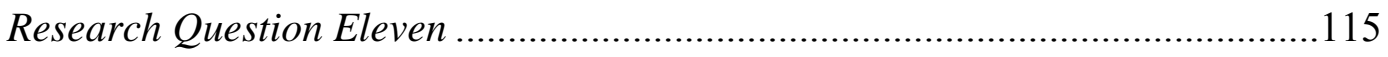

Decision to Teach Before Entering College …………........................................115

Decision to Teach after Student Teaching .....................................................117

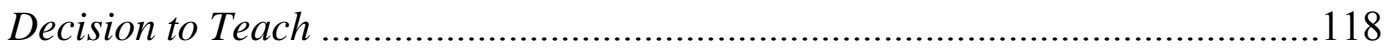

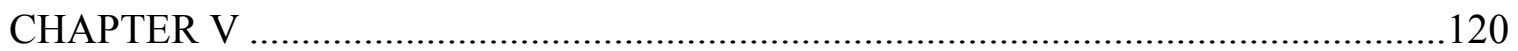

Summary, Conclusions, and Recommendations ..................................................120

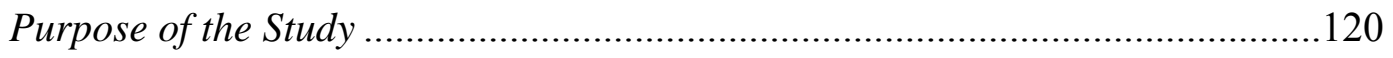

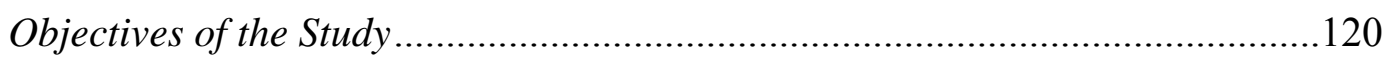

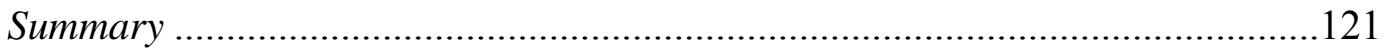

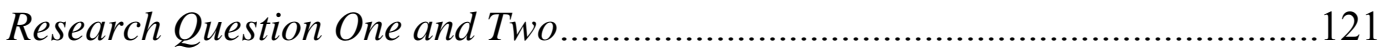

Research Question Three ........................................................................122

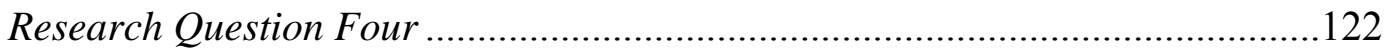

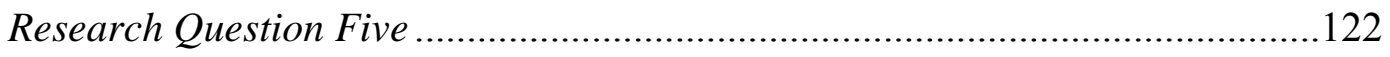

Research Question Six ............................................................................123

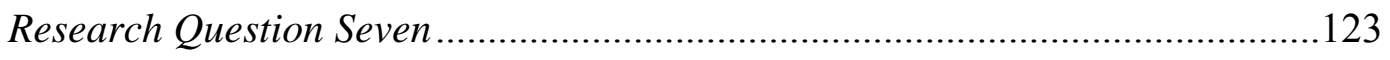

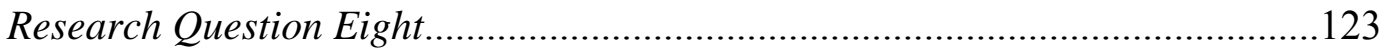

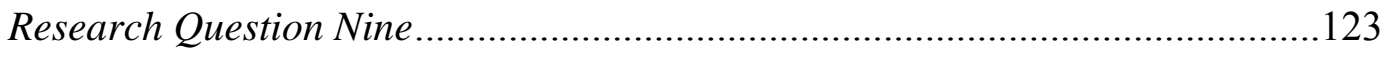

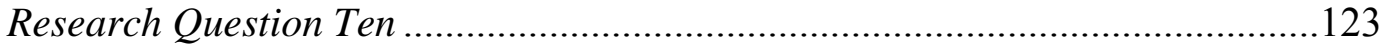

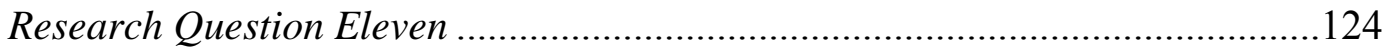

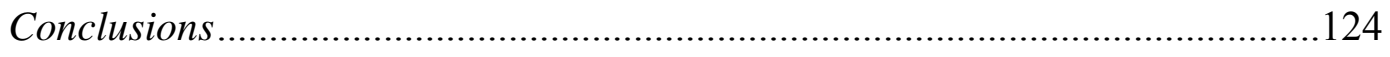

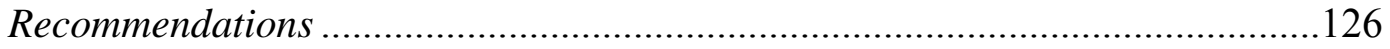


REFERENCES

APPENDIX A: Questionnaire

APPENDIX B: Initial Post Card.

APPENDIX C: Cover Letter.

APPENDIX D: First Follow-Up Postcard

APPENDIX E: Follow-Up Cover Letter ......

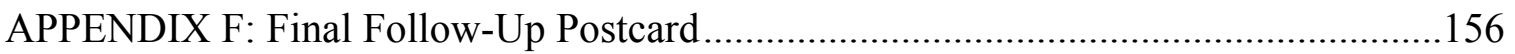

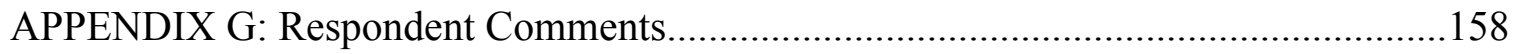

VITA

164 


\section{LIST OF TABLES}

Table Title

Page

1 Demographic Characteristics of Respondents

2 Status of Teacher Certification in Agricultural Education of Individuals Who Completed a Student Teaching Experience

3 Teaching Status of Individuals who had Completed a Student Teaching Experience.

$4 \quad$ Factors Involved in the Student Teaching Site Selection for Individuals Who Completed a Student Teaching Experience ……………...............31

$5 \quad$ Role of Cooperating Teachers during Student Teaching .39

$6 \quad$ Role of the University Supervisor during Student Teaching.

$7 \quad$ School and Community Support Encountered by Individuals who Completed a Student Teaching Experience.

$8 \quad$ Classroom and Laboratory Experiences of Individuals who Completed a Student Teaching Experience

9 Involvement in FFA Activities during Student Teaching .....................................50

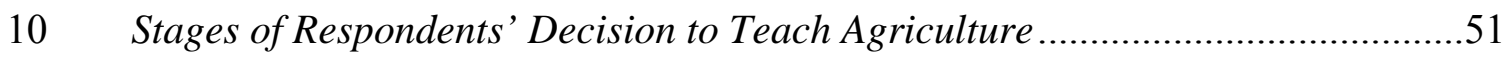

11 Number of University Supervisor Visits to Student Teachers ..............................52

12 Number of SAE Visits Conducted during Student Teaching .................................53

13 Membership in the National FFA Organization of Individuals who Completed a Student Teaching Experience...................................................53

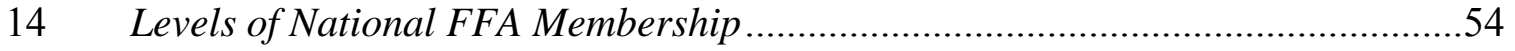

15 Years of Active FFA Membership of Individuals who had Completed a Student Teaching Experience

16 Highest FFA Degree Earned by Individuals who had Completed a Student Teaching Experience.

17 Types of Supervised Agricultural Experience Programs (SAE)

Conducted by Individuals who Completed a Student Teaching

Experience.

18 Chapter FFA Offices Held by Individuals who had Completed a Student Teaching Experience.

19 State FFA Offices Held by Individuals who Completed a Student Teaching Experience.

20 Participation in Leadership Conferences during Years of FFA

Membership by Individuals who Completed a Student Teaching Experience 
21 Participation in FFA Career Development Events (CDE) during

Years of FFA Membership by Individuals who Completed a

Student Teaching Experience

22 Participation in FFA Activities during Years of FFA

Membership by Individuals who Completed a Student Teaching

Experience.

23 Highest Level of FFA Proficiency Awards Earned during Years

of FFA Membership by Individuals who Completed a Student

Teaching Experience.

24 4-H Membership of Individuals who Completed a Student

Teaching Experience.

25 Years of 4-H Participation of Individuals who Completed a

Student Teaching Experience.

26 Participation in 4-H Projects by Individuals who Completed a

Student Teaching Experience.

27 Participation in 4-H Projects by Individuals who Completed a

Student Teaching Experience.

28 4-H Club Offices Held by Individuals who completed a Student

Teaching Experience.

29 Participation in 4-H Activities by Individuals who Completed a

Student Teaching Experience.

30 Student Teaching Site Selection Variables for Satisfied and

Dissatisfied Individuals

31 Comparison of Means of Student Teaching Site Selection

Variables for Satisfied and Dissatisfied Individuals.

32 Cooperating Teacher Characteristics for Satisfied and

Dissatisfied Individuals.

33 Comparison of Means of Cooperating Teacher Characteristics

of Satisfied and Dissatisfied Individuals.

34 University Supervisor Variable for Satisfied and Dissatisfied

Individuals.

35 Comparison of Means of University Supervisor Characteristics

of Satisfied and Dissatisfied Individuals

36 Factors Influencing Participants Decision to Teach Agriculture

37 Number of Chapter FFA Offices held by Individuals who are Currently Teaching or who Taught Agricultural Education in the Past. 
38 Number of State FFA Offices held by Current Individuals who are Currently Teaching or who Taught Agricultural Education in the Past

39 Number of Leadership Activities attended by Individuals who are Currently Teaching or who Taught Agricultural Education in the Past

40 Number of CDEs Competitions completed by Individuals who are Currently Teaching or who Taught Agricultural Education in the Past

41 Number of FFA Activities Participated in by Individuals who are Currently Teaching or who Taught Agricultural Education in the Past

42 Differences in FFA Involvement between Individuals who did and did not Cite "FFA Involvement" as a Factor Influencing an Individual to Teach Agriculture.

43 Comparison of Means of FFA Involvement.....

$44 \quad$ Number of 4-H Club Offices Held by Individuals who did and did not Cite "4-H Involvement" as a Factor Influencing an Individual to Teach Agriculture.

45 Number of 4-H State Offices Held by Individuals who did and did not Cite "4-H Involvement" as a Factor Influencing an Individual to Teach Agriculture....

46 Number of 4-H Activities Participated in by Individuals who did and did not Cite"4-H Involvement" as a Factor Influencing an Individual to Teach Agriculture.

47 Differences in 4-H Involvement between Individuals who did and did not Cite "4-H Involvement" as a Factor Influencing an Individual to Teach Agriculture.

48 Comparison of Means of 4-H Involvement

49 Factors Influencing Participants' Decision not to Teach

Agriculture

50 Timing of Teaching Decision for Individuals who Never Taught Agricultural Education

51 Occupation Status of those not Teaching Agriculture

52 Factors Influencing an Individual's Decision to Leave Teaching Agriculture

53 Agricultural Youth Organization Involvement of Participants

54 Comparison of Means of Agricultural Youth Organization Involvement and Decision to Teach when Entering College 
55 Means of Agricultural Youth Involvement and Decision to Teach

After Student Teaching.........................................................................................115

56 Discriminant Analysis of Decision to Teach when Entering

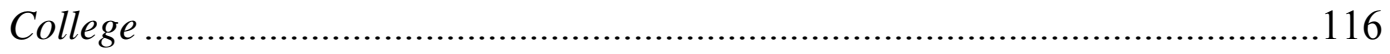

57 Disciminant Analysis of Decision to Teach after Student

Teaching .........................................................................................................117

58 Discriminant Analysis of Decision to Teach ..........................................................118 


\section{CHAPTER I}

Introduction

Agricultural education has continuously evolved since its formal inception as Vocational Agriculture in 1917 with the adoption of the Smith-Hughes Act. Much of this change is due in part to changes in the agricultural industry, the education system, and the characteristics of students who enroll in agricultural education programs. With these changes, new challenges are created and old challenges persist. One of the challenges that has remained at the forefront of the profession is the shortage of qualified agricultural education teachers. According to the National Study of the Supply and Demand for Teachers of Agricultural Education From 2004-2006, “a de-facto 'teacher shortage' has been a constant problem for Agricultural Education for at least the 40 years covered by this study" (Kantrovich, 2007, p. 3).

The demand for agricultural educators will continue to grow as new incentives and goals are set forth by the profession. The most recent plan for agricultural education is the "10x15" goal. This "Long-Range Strategic Goal" calls for 10,000 quality agricultural science programs to be in place by the year 2015 (Team Ag Ed, n.d.). In order to meet this demand, the number of qualified teachers entering the agricultural education profession must increase. According to a recent study by Kantrovich (2007), in 2006 the number of agricultural education positions exceeded the number of qualified teachers by 78 . It is estimated that 40 agricultural education programs will or no longer operate due to the teacher deficiency (Kantrovich, 2007). The "10x15" goal can be met only if there is a change in the supply trend of qualified agricultural education teachers. 
The supply of teachers hinges on the decision of individuals to choose a career in agricultural education, enroll in college, complete training, and seek a teaching position upon graduation. According to Bandura (1986), the process of choosing a career begins early in one's life. The decision is influenced and shaped by various environmental and experiential factors. Many of these factors are fostered by observing and modeling people who the individual has had contact (Bandura, 1986). In the case of individuals who pursue a career teaching agriculture, many have background experience in agricultural youth organizations such as the National FFA Organization and/or the 4-H organization (Hovatter, 2002; Rocca \& Washburn, 2006). Along with involvement in those agricultural youth organizations, individuals have the opportunity to observe and interact with professionals tied to those organizations, including agriculture teachers and Extension personnel. Whether or not those individuals realize it, they are impacting the career decisions of the youth they advise (Cotton, 2005; Radhakrishna, 2005).

\section{Problem Statement}

Every year, institutions responsible for agricultural teacher education are charged with the task of producing enough qualified graduates who will enter the work force and fill teaching vacancies. In 2006, it was estimated that the net demand for agriculture teacher replacements included 824 positions nationwide. The number of newly qualified teachers available for the 2005-2006 school year was 785; and of those 785 , it was estimated by college professors that 705 of those individuals "probably wanted to teach" (Kantrovich, 2007). Considering the individuals who were qualified to teach, this creates a deficit of at least 39 teaching positions. However, the deficit widens even more when one considers the occupations actually entered by those who were qualified to teach. Of 
the 785 qualified to teach, only 548 individuals were employed to teach agriculture; 46 were teaching another subject; 27 were working for the extension service; 104 were employed by an agribusiness; and 75 were completing graduate work (Kantrovich, 2007).

Similar results have occurred in West Virginia. Between 2001-2005, 32 students were qualified to teach agriculture. Of those 32 individuals, 13 people (41\%) entered a teaching career in agriculture. One individual (3\%) taught for a year and then left teaching. Of the 20 qualified teachers not employed in teaching, seven were working for an agribusiness or government agency; four people were employed by the Extension service; seven individuals entered graduate school; and two people had a status of "unknown" (Boone, 2006). Therefore, the real problem lies not only in the number of qualified teachers being produced by teacher education programs, but includes the number of qualified individuals who actually decide to enter the agriculture teaching profession.

The differences that exist between the number of individuals who are qualified to teach and the number who actually enter a career in teaching agriculture cause a number of red flags to be raised. First, why do individuals decide to teach agriculture? Why are individuals not entering the agricultural education profession even after earning a degree in agricultural education and becoming certified to teach? Also, of those who enter the agricultural teaching field, why do some individuals leave teaching?

\section{Purpose of the Study}

The purpose of this study was to determine the factors that influence an individual's decision to teach agricultural education. This study was designed to explore these factors in order to provide universities, teacher educators, and agricultural educators 
with information to aid the recruitment and retention of individuals who will enter a teaching profession in agricultural education.

\section{Objectives of the Study}

The objectives of the study are reflected in the following research questions:

1. What were the student teaching site selection processes, cooperating teacher characteristics, and university supervisor characteristics associated with individuals who were not satisfied with the student teaching experience?

2. What were the student teaching site selection processes, cooperating teacher characteristics, and university supervisor characteristics associated with individuals who were satisfied with the student teaching experience?

3. What did participants identify as factors that influenced their decision to teach agriculture?

4. What was the level of participation in the FFA for those who cited "FFA involvement" as a factor influencing their decision to teach agriculture?

5. What was the level of participation in 4-H for those who cited "4-H involvement" as a factor influencing their decision to teach agriculture?

6. For those who did not enter the agricultural teaching profession, what reason(s) did respondents identify for not teaching agriculture?

7. When did the participants who never taught agriculture decide not to teach?

8. What were the occupations of those who did not teach agriculture?

9. What were the factors that influenced an individual to leave the agricultural teaching field? 
10. What was the relationship between a respondent's involvement in agricultural youth organizations (FFA and 4-H) and the decision to teach agriculture?

11. What components of an individual's background had the most impact on their decision to teach agriculture?

\section{Limitations of the Study}

Limitations for the study included insufficient addresses for the population of the study. The population included individuals who student taught between 2002 and 2005 while attending Clemson University, North Carolina State University, The Pennsylvania State University, Virginia Polytechnic Institute and State University, and West Virginia University. The names of those who were included in the population were obtained, but some were lacking sufficient contact information.

\section{Definitions}

4-H- The youth development outreach of Land Grant Universities, the Cooperative Extension System, and USDA made up of a community of young people across America who are learning life skills (National 4-H Headquarters, n.d, A).

4-H project- Activities conducted for youth to practice and learn life skills based on 4-H project curricula (National 4-H Headquarters, n.d., B).

Career Development Event (CDE) - Events designed to help prepare students for careers in agriculture by demonstrating skills learned during classroom and laboratory instruction in a competitive setting (National FFA Organization, n.d., A).

Cooperating teacher- Classroom teacher who agrees to provide daily guidance, counsel, and supervision of the student teacher in cooperation with the university and university supervisor (Berryhill, 2005). 
National FFA Organization- A national youth organization for students enrolled in agricultural courses dedicated making a positive difference in the lives of students by developing their potential for premier leadership, personal growth, and career success through agricultural education (National FFA Organization, n.d., C).

Student teacher- A university senior or graduate student engaged in an internship in the cooperating school under the supervision and guidance of the cooperating teacher and university supervisor (Berryhill, 2005).

Student teaching experience- The experience in the teacher training program prior to graduation and teacher certification (Berryhill, 2005).

Supervised Agricultural Experience Program (SAE)- planned agricultural activity that uses the hands-on application of knowledge learned in the agricultural classroom and laboratory which supports skill and competency development and career success (National FFA Organization, n.d., B).

University supervisor- The university representative who serves as a liaison between the university and the school and serves as a support person for the student teacher and cooperating teacher (Berryhill, 2005). 


\section{CHAPTER II}

\section{Review of Literature}

The review of literature addressed the common or ideal practices that are being used for or during student teaching experiences and the characteristics that often define the total field experience. The components of the student teaching experience are thought to be the student teacher, cooperating teacher, university supervisor, and the student teaching site. The student teaching site is generally characterized by elements of classroom/laboratory, Supervised Agricultural Experience Programs (SAE), and FFA activities. It was also necessary to explore the reasons why individuals choose teaching as a career choice and what influences an individual's involvement in agricultural youth organizations (National FFA Organization and 4-H) may have on a career choice.

\section{Student Teachers}

"Student teachers themselves are the most important key to a successful student teaching experience" (Willems, Tollakson, Milburn, Connor, \& Hull, 1986, p. 193). As defined by the WVU Student Teaching Handbook (Berryhill, 2005), student teachers have specific roles and responsibilities to fulfill during the experience. Student teachers are to do the following: act professionally; keep personal responsibilities, i.e. employment, at a minimum; become familiar with school facilities and regulations; assist the cooperating teacher with responsibilities outside of the classroom; take on normal classroom duties; employ different teaching techniques; evaluate student progress; and continue to complete university required assignments.

Willems, et al. (1986) listed guidelines that most successful student teachers

follow. Successful student teachers have good organizational skills, use a "open, honest" 
line of communication among/between his/her cooperating teacher and university supervisor, are enthusiastic about teaching, devote an overwhelming amount of time to student teaching, and operate in a professional manner.

\section{Cooperating Teachers}

Other than the student teacher, the cooperating teacher has been identified as the most important element of the student teaching experience (Edwards \& Briers, 2001; Norris, Larke, and Briers, 1990; Willems, et al., 1986). In a study by Harlin, Edwards, and Briers (2002), student teachers believed the cooperating teacher-student teacher relationship was the most important element of the student teaching experience.

The roles of cooperating teachers, as outlined in the WVU Student Teacher Handbook (Berryhill, 2005), include the following: getting to know the student teacher; creating opportunities for observation; evaluation, planning, and classroom management; making the student teacher aware of school policies, staff, and resources; and evaluating student progress. According to Willems, et al. (1986), cooperating teachers can promote a positive student teaching experience by using the following guidelines: prepare the class for an additional teacher, provide the student teacher with his/her own desk, share philosophies with student teachers, provide feedback and suggestions for improvement, leave the room for short periods of time, foster good communication with the student teacher, and provide opportunities for student teachers to attend professional meetings.

Qualities of cooperating teachers as listed by Norris, et al. (1990) included: possess a willingness to devote time to the student teacher, have the ability to motivate students, have a personal philosophy of agricultural education, and have an understanding of university goals for teacher education. Norris, et al. (1990) found that teacher 
educators believed the ideal cooperating teacher should have a master's degree, be identified by others in the profession as a leader, have displayed continuous professional growth, have taught in a local school for three years, and have a minimum of five years of teaching experience. Teacher educators and teachers who had or were serving as cooperating teachers were strong in their belief that student teachers and cooperating teachers should be matched according to personalities and other characteristics, and the cooperating teacher-student teacher relationship is a very important aspect of the student teaching experience (Edwards \& Briers, 2000; Norris, et al., 1990).

Martin and Yoder (1985) found the supervisory climate created by cooperating teachers to be an important contributing factor to the success of the student teaching experience. A cooperating teacher who supervises a student teacher effectively will gradually decrease the student teacher's dependence on authority and help him or her grow as a teacher. An open line of communication was an important factor identified by student teachers who were satisfied with their supervising teachers (Rome \& Moss, 1990).

\section{University Supervisors}

The university supervisor is "charged with the responsibility to coordinate the student teaching experience" (Martin \& Yoder, 1985, p.16). This includes placement of the student teacher at a school site and frequent evaluative visits to the student teaching site. Morrish, Harlin, Briers, Shinn, and Hoyle (2003) reported that head teacher educators felt the method of student teacher placement should be a joint effort of the agricultural education faculty and the student teacher. According to Martin and Yoder (1985) the student teacher should meet with the university supervisor prior to student 
teaching to outline supervisory procedures. The university supervisor should observe the student teacher during the field experience and discuss what he/she observed during the student teacher's teaching. The university supervisor should also provide the student teacher with a copy of the evaluation so reflection and changes can be made, as needed. (Berryhill, 2005; Martin \& Yoder, 1985; Willems, et al., 1986).

\section{Student Teaching Sites}

Teacher educators participating in a study by Norris, et al. (1990) wanted student teaching centers to not be multi-teacher departments, have an active adult/young farmer program, have a record of accomplishments, have cooperation from the administration, have modern equipment, a clean safety record, an updated library, and be located within a high school. Harlin, Edwards, and Briers (2002) conducted a study to describe characteristics of cooperating teaching centers and the facilities included at the surveyed locations were agricultural mechanics shops, greenhouses, project centers, meats laboratories, aquaculture laboratories, and land laboratories. Student teaching centers also had access to internet and computer laboratories (Harlin, et al., 2002).

Harlin, et al. (2002) studied the important elements as perceived by student teachers before and after their student teaching experience. Classroom and laboratory instruction was recognized as an important element both before and after the student teaching experience. The focus groups conducted by Edwards and Briers (2000) also listed classroom and laboratory instruction as an important element of the student teaching experience.

Student teachers surveyed before and after their student teaching experience listed the requirement of approved supervised agricultural experiences by the cooperating 
teacher as an important element of their student teaching site (Harlin, et al., 2002).

Additionally, teacher educators in a study by Morrish, et al. (2003) identified important elements of cooperating centers to include SAE programs.

Morrish, et al. (2003) listed important elements of the cooperating site to include an active FFA chapter. Student teachers also perceived student leadership development as an important aspect of their student teaching sites (Harlin, et al., 2002). Edwards and Briers (2000) also found that cooperating teachers view student leadership development (FFA) as an important element of student teaching experiences.

\section{Classroom/Laboratory Instruction}

Harlin, et al. (2002) studied the important elements as perceived by student teachers before and after their student teaching experience. Classroom and laboratory instruction was recognized as an important element both before and after the student teaching experience. The focus groups conducted by Edwards and Briers (2000) also listed classroom and laboratory instruction as an important element of the student teaching experience.

\section{Supervised Agricultural Experience}

Student teachers surveyed before and after their student teaching experience listed the requirement of approved supervised agricultural experiences by the cooperating teacher as an important element of their student teaching site (Harlin, et al., 2002). Additionally, teacher educators in a study by Morrish, et al. (2003) identified important elements of cooperating centers to include SAE programs. 


\section{FFA Activities}

Morrish, et al. (2003) listed important elements of the cooperating site to include an active FFA chapter. Student teachers also perceived student leadership development as an important aspect of their student teaching sites (Harlin, et al., 2002). Edwards and Briers (2000) also found that cooperating teachers view student leadership development (FFA) as an important element of student teaching experiences.

\section{Background in Agricultural Youth Organizations (FFA and 4-H)}

Wildman and Torres (2001) found factors that influenced an individual to major in agriculture in college included agricultural experiences, such as FFA and 4-H activities related to agriculture, and enrollment in agricultural courses in high school. The study also found that agricultural professionals had an influence on the participants' decisions, but Extension professionals and vocational agriculture teachers did not impact their decision to major in agriculture in college.

Kasperbauer and Roberts (2007) surveyed preservice teachers to determine what factors were predictive of the individual's decision to teach agriculture. The study found that the semesters of high school agricultural courses taken was indicative of the participants' decisions to enter a career in teaching agriculture.

In study by Radhakrishna (2005), individuals with a 4-H background were asked to indicate the level of influence their participation had on career and life experiences. Individuals indicated that their 4-H involvement had an influence on their continuation of high school and beyond. Participants also indicated 4-H prepared them for leadership responsibilities after membership (Radhakrishna, 2005). 


\section{Choosing a Teaching Career}

Career choice can be influenced by a variety of factors. Choosing a career in teaching is no different. In a study by Schutz, Crowder, and White (2000), individuals enrolled in a teacher training program were interviewed to determine the influences that had lead to their decision to teach. The ten types of influences identified by the participants were altruistic motives (wanted to help society), past experiences, past teachers, personal characteristics, parents or family, love of children, peers, selfbenefiting, interest in subject, and parenting.

Hovatter (2002) found that preservice teachers agreed that their decision to enter teaching was impacted by influences of family, friends, their high school agricultural teacher, and an enjoyable student teaching experience. Cotton (2005) also found that the majority of current agricultural education teachers were influenced by other high school agriculture teachers. Individuals not teaching agriculture indicated the following factors had the most influence on their decision not to teach: pursuing another career, pursuing Master's degree, married, no jobs open in local area, no teaching jobs open, and looking for interesting job prospect (Hovatter, 2002).

A study conducted by Harms and Knobloch (2005) measured the intrinsic and extrinsic motives that lead preservice teachers to enter a teaching career in agriculture. Individuals planning to enter a career in teaching based their decision on intrinsic motives, compared to individuals who were not planning to teach or were undecided. Intrinsic reasons included serving others, touching people's lives/making an impact, and 'calling' to a career. Respondents who were not going to teach made their decision based more on extrinsic reasons compared to undecided individuals. Those motives included 
salary and benefits, balance between career and personal time, and opportunities for advancement and personal growth. People who were undecided regarding their career decision had intrinsic and extrinsic reasons (Harms \& Knobloch, 2005).

\section{Summary}

Important components of the student teaching experience included the individuals involved, the student teaching placement site, and the student teacher's exposure to the components of a total agricultural program (FFA, SAE, and classroom/laboratory). The three individuals most important to the student teaching experience were the student teacher, cooperating teacher, and university supervisor. The roles and responsibilities of these individuals had an impact on the overall student teaching experience. It was important for student teaching sites to have adequate facilities to provide enough opportunities for student teachers to gain experience in classroom and laboratory settings. Student teachers needed to be guided by the cooperating teacher to complete SAE visits and help with FFA activities.

Background experiences in the National FFA Organization and 4-H organization have shown to impact the career decisions of past members. Many individuals chose agriculture as a college major or decided to pursue a career teaching agriculture because of their involvement in the aforementioned organizations. Other influences on an individual's choice to pursue a career teaching agricultural education included intrinsic and extrinsic factors. Intrinsic influences were serving others, touching people's lives/making an impact, and 'calling' to a career. Extrinsic influences were family, friends, their high school agricultural teacher, salary and benefits, and an enjoyable student teaching experience. 


\section{CHAPTER III}

\section{Methodology}

\section{Purpose of the Study}

The purpose of this study was to determine the effect of a group of select factors on an individual's decision to teach agricultural education. The factors included participation in agricultural youth organizations; the student teaching experience; and the influence of an agricultural background, family, friends, and teachers. This study was designed to explore these factors in order to provide universities, teacher educators, and agricultural educators with information to aid the recruitment and retention of individuals who will enter a teaching profession in agricultural education.

\section{Objectives of the Study}

The objectives of the study are reflected in the following research questions:

1. What were the student teaching site selection processes, cooperating teacher characteristics, and university supervisor characteristics associated with individuals who were not satisfied with the student teaching experience?

2. What were the student teaching site selection processes, cooperating teacher characteristics, and university supervisor characteristics associated with individuals who were satisfied with the student teaching experience?

3. What did participants identify as factors that influenced their decision to teach agriculture?

4. What was the level of participation in the FFA for those who cited "FFA involvement" as a factor influencing their decision to teach agriculture? 
5. What was the level of participation in $4-\mathrm{H}$ for those who cited " $4-\mathrm{H}$ involvement" as a factor influencing their decision to teach agriculture?

6. For those who did not enter the agricultural teaching profession, what reason(s) did respondents identify for not teaching agriculture?

7. When did the participants who never taught agriculture decide not to teach?

8. What were the occupations of those who did not teach agriculture?

9. What were the factors that influenced an individual to leave the agricultural teaching field?

10. What was the relationship between a respondent's involvement in agricultural youth organizations (FFA and 4-H) and the decision to teach agriculture?

11. What components of an individual's background had the most impact on their decision to teach agriculture?

\section{Research Design}

A descriptive research design, in the form of a census survey, was used to collect data for this study. This design was used to determine the demographics, characteristics, and perceptions of the population. Ary, Jacobs, Razavieh, and Sorenson (2006) define the purpose of descriptive research as gathering information from a population in order to summarize their characteristics and measure attitudes and opinions toward some issue. A survey was used to expand the accessible population beyond the limits of the researcher's location. By using a mailed survey, participants could be reached regardless of location.

\section{Population}

The target population of this study was individuals who student taught between 2002-2005 while attending Clemson University, North Carolina State University, The 
Pennsylvania State University, Virginia Polytechnic Institute and State University, and West Virginia University. Lists of individuals were secured from the Agricultural Education Departments of the respective universities $(N=278)$. The accessible population was limited to the individuals who had up-to-date contact information $(N=$ 222). Once the instrument was sent, five mailings were returned due to insufficient addresses and/or no forwarding address, leaving the accessible population at $N=217$.

Instrumentation

The questionnaire consisted of 82 questions and was developed based on background research conducted by the researcher. The questionnaire was divided into three sections and utilized a combination of Likert, multiple choice, and open-ended items.

The first section addressed the student teaching experience. Individuals were asked to respond to questions about the student teaching site selection process, cooperating teacher, university supervisor, and student teacher performance using the following Likert scale: 1 - strongly disagree, 2- moderately disagree, 3- slightly disagree, 4- slightly agree, 5- moderately agree, and 6- strongly agree.

The second section of the questionnaire involved background in agricultural youth organizations. Individuals who participated in the National FFA Organization and/or 4-H organization were asked to identify the activities in which they participated during their years of membership. Participants were asked to indicate various activities, leadership responsibilities, and agricultural enterprises (Supervised Agricultural Experience and/or 4-H projects) they completed during membership using multiple choice and open-ended questions. 
Section three involved the career status of the respondents. Individuals were asked to indicate their current occupation or future occupation plans. Individuals who planned to teach agriculture, were currently teaching, or had taught agriculture were asked to identify factors influencing their decision to teach agriculture. Individuals who were not currently teaching agriculture or exited the profession were asked to identify factors influencing their decision for leaving or not entering the profession.

Validity of the Instrument. The revised instrument was presented to a panel of experts to establish its content and face validity. The panel of experts consisted of faculty members in the department of Agricultural and Extension Education at West Virginia University. Members of the panel had experience in teaching, extension, and research. The panel of experts concluded that the instrument had content and face validity.

Reliability of the Instrument. Reliability is the ability of the scores produced by an instrument to be consistent, repeatable, dependable, and generalized (Ary et al., 2006). The final data set from all respondents was used to determine the instrument's reliability. The 50 Likert scale items were tested for reliability by using the Spearman-Brown split half statistic coefficient. Reliability was found to be exemplary with a Spearman-Brown coefficient of .63 (Robinson, Shaver, \& Wrightsman, 1991). The instrument was found to be reliable.

\section{Data Collection Procedures}

Dillman's (2000) tailored design method was used to collect the data. A preliminary post-card was sent on March 12, 2007 to inform the participants they would be receiving the questionnaire. A packet consisting of a cover letter introducing and explaining the purpose of the study, a questionnaire, and a stamped, self addressed 
envelope was sent on March 15, 2007. Participants were given a deadline date of March 31, 2007 to complete and return the survey. The first mailing yielded 81 responses. A follow-up post-card was sent on April 4, 2007 to remind individuals that their responses had not been received. A second packet with a cover letter, questionnaire, and a stamped, self addressed envelope was sent on April 9, 2007 to the individuals who did not respond to the initial mailing. A second deadline of April 20, 2007 was given for the completion questionnaire. At the end of the second deadline, a second follow-up post-card was sent on April 25, 2007 to each of the non-respondents. The second mailing resulted in 36 returned surveys, making the total number of respondents 117 out of $217(54 \%)$ possible participants.

Analysis of Data

Each respondent was identified by a numerical code located on the survey. This code was utilized to follow-up non-respondents. Later the code key was destroyed to protect the anonymity of the respondents. Data were entered into an Excel spreadsheet. Answers to questions requiring an open-ended response were documented in full text format and grouped together based on like responses.

The Statistical Package for the Social Sciences (SPSS) 11.0 for Windows was used to analyze the data collected for this study. Likert questions which were written in a negative fashion were reverse coded to be positive statements. This included question numbers $2,11,16,2533,40,43,46$, and 50. Descriptive analyses were performed on the data, and the appropriate methods of reporting central tendency and variability for each type of data were used. 
Independent $t$-tests were used to compare the level of participation of those who cited "FFA involvement" and/or "4-H involvement" as a factor influencing their decision to teach agriculture versus individuals who did not identify those factors as influences. For the research questions dealing with student teaching satisfaction, the responses from the Likert scale questions associated with the overall student teaching experience (question numbers 44,45 , and 46 ) were averaged. Those averages were then recoded into "satisfied" and "dissatisfied" categories. The "dissatisfied" category consisted of the averaged values ranging from 0-3.5. The "satisfied" category included the averaged values ranging from 3.51-6.0. Independent $t$-tests were also used to compare the means of the 50 Likert scale item responses of individuals who were teaching and the individuals who were not teaching.

The responses from questions 75,77 , and 78 were reverse coded and a sum was calculated. The sums were then sorted in ascending order to rank the top factors influencing an individual to teach agriculture, leave teaching, or not teach agriculture.

Discriminant analysis was performed to determine what factors can be used to predict the different decisions about teaching agriculture. These decisions included "wanted to teach before entering college," "wanted to teach after student teaching," and "are you currently teaching?"

Non-response error. Non-response error was addressed by comparing early respondents to late respondents. A chi-square test of independence was performed to determine if there was a significant relationship between early and late respondents. The following variables were used: membership in the National FFA Organization, membership in the 4-H organization, current agricultural teaching status, gender, and age. 
The chi-square values were not significant $(\alpha \leq .05)$. It was concluded that nonrespondents were similar to respondents (Ary et al., 2006), therefore generalization could be made to the entire population.

\section{Use of Findings}

Findings from this study can be used by individuals involved with the recruitment and retention of individuals considering the agricultural teaching profession. This may include, but is not limited to, agricultural teachers and FFA advisors, Extension agents, 4-H leaders, state agricultural education staff, and staff involved with agricultural teacher education. Also, results associated with student teaching components and overall satisfaction of student teaching can be used by institutions involved with agricultural teacher education to make changes and improve the processes and activities that are related to the student teaching experience. 


\section{CHAPTER IV}

\section{Findings}

\section{Purpose of the Study}

The purpose of this study was to determine the effect of a group of select factors on an individual's decision to teach agricultural education. The factors included participation in agricultural youth organizations; the student teaching experience; and the influence of family, friends, and teachers. This study was designed to explore these factors in order to provide universities, teacher educators, and agricultural educators with information to aid the recruitment and retention of individuals who will enter a teaching profession in agricultural education.

\section{Objectives of the Study}

The objectives of the study are reflected in the following research questions:

1. What were the student teaching site selection processes, cooperating teacher characteristics, and university supervisor characteristics associated with individuals who were not satisfied with the student teaching experience?

2. What were the student teaching site selection processes, cooperating teacher characteristics, and university supervisor characteristics associated with individuals who were satisfied with the student teaching experience?

3. What did participants identify as factors that influenced their decision to teach agriculture?

4. What was the level of participation in the FFA for those who cited "FFA involvement" as a factor influencing their decision to teach agriculture? 
5. What was the level of participation in $4-\mathrm{H}$ for those who cited " $4-\mathrm{H}$ involvement" as a factor influencing their decision to teach agriculture?

6. For those who did not enter the agricultural teaching profession, what reason(s) did respondents identify for not teaching agriculture?

7. When did the participants who never taught agriculture decide not to teach?

8. What were the occupations of those who did not teach agriculture?

9. What were the factors that influenced an individual to leave the agricultural teaching field?

10. What was the relationship between a respondent's involvement in agricultural youth organizations (FFA and 4-H) and the decision to teach agriculture?

11. What components of an individual's background had the most impact on their decision to teach agriculture?

\section{Findings}

The target population included 222 individuals who student taught from 20022005 while attending the following universities: Clemson University, North Carolina State University, The Pennsylvania State University, Virginia Polytechnic Institute and State University, and West Virginia University. Due to the lack of forwarding addresses for five individuals, the accessible population for this study consisted of 217 individuals. Of the 217 questionnaires, 117 surveys (54\%) were returned.

\section{Demographic Characteristics of Respondents}

Fifty-four (46.15\%) of the respondents were male and $63(53.85 \%)$ were female. Of the respondents, 28 individuals (23.93\%) had attended Clemson University; 33 individuals (28.21\%) had attended North Carolina State University; 13 people $(11.11 \%)$ 
had attended The Pennsylvania State University; 24 respondents (20.51\%) had attended Virginia Polytechnic Institute and State University; and 19 individuals (16.24\%) had attended West Virginia University (see Table 1).

The median age category of the respondents was 23-25 years. Two respondents (1.71\%) were between the ages $20-22$. The number of individuals in the 23-25 years of age category totaled sixty-three (53.85\%). Forty-three respondents (36.75\%) were 26-28 years old. Five individuals (4.27\%) were 29-31 years old, and four respondents (3.42\%) were in the 35 or older age category (see Table 1).

Table 1

Demographic Characteristics of Respondents

\begin{tabular}{lrc}
\hline & $N$ & $\%$ \\
\hline Gender & 54 & 46.15 \\
$\quad$ Male & 63 & 53.85 \\
Female & & \\
& 28 & \\
University Attended During Student Teaching & 33 & 23.93 \\
Clemson University & 13 & 28.21 \\
North Carolina State University & & 11.11 \\
The Pennsylvania State University & 24 & \\
Virginia Polytechnic Institute and State & 19 & 20.51 \\
University & & 16.24 \\
West Virginia University & & \\
& 2 & \\
Age Category & 63 & 1.71 \\
$20-22$ & 43 & 33.85 \\
$23-25$ & 5 & 36.75 \\
$26-28$ & 4 & 3.27 \\
$29-31$ & & \\
35 or greater & & \\
\end{tabular}




\section{Status of Teacher Certification in Agricultural Education}

Of the participants who responded to the question addressing agricultural education teacher certification status, 102 respondents $(91.89 \%)$ were certified to teach. Four respondents $(3.60 \%)$ did not or will not apply for teacher certification in agricultural education. Five individuals (4.50\%) became certified but let his/her certification expire (see Table 2).

Table 2

Status of Teacher Certification in Agricultural Education of Individuals Who Completed a Student Teaching Experience

\begin{tabular}{lrr}
\hline Status & $N$ & $\%$ \\
\hline Certified to teach & 102 & 91.89 \\
Did not or will not apply for certification & 4 & 3.60 \\
Became certified to teach but let certification expire & 5 & 4.50 \\
\hline
\end{tabular}

\section{Teaching Status of the Respondents}

Respondents identified their current teaching status. Of the participants who responded, 82 individuals $(70.09 \%)$ were currently teaching agriculture. Participants who were not currently teaching were asked if they had ever taught, and of those who responded, six of the 32 individuals $(18.75 \%)$ had taught agriculture. Twenty-six of the 32 individuals (81.25\%) who were not currently teaching had never taught agriculture. Of the 25 individuals who responded, six participants (24.00\%) planned to teach and 19 people $(76.00 \%)$ did not plan to teach (see Table 3 ). 
Table 3

Teaching Status of Individuals Who had Completed a Student Teaching Experience

\begin{tabular}{lccrcc}
\hline Teaching Status & \multicolumn{2}{c}{ No } & \multicolumn{2}{c}{ Yes } \\
& $N$ & $\%$ & 82 & $\%$ \\
\hline Are you currently teaching? & 35 & 29.91 & 6 & 70.09 \\
Did you ever teach? & 26 & 81.25 & 6 & 18.75 \\
Do you plan to teach? & 19 & 76.00 & 6.00 \\
\hline
\end{tabular}

Factors Involved in Student Teaching Site Selection

Participants were asked to respond to questions regarding their student teaching site placements. This section consisted of 11 Likert type statements, with answer options including strongly disagree, moderately disagree, slightly disagree, slightly agree, moderately agree, and strongly agree.

The median response was the individuals moderately agreed that the selection of his/her student teaching site was solely his/her selection. Nine respondents $(7.69 \%)$ strongly disagreed that the selection of his/her student teaching site was solely his/her decision. Four individuals $(3.42 \%)$ moderately disagreed that the selection of his/her student teaching site was solely his/her decision. Thirteen individuals (11.11\%) slightly disagreed that the selection of his/her student teaching site was solely his/her decision. Twenty-one participants (17.95\%) slightly agreed that the selection of his/her student teaching site was solely his/her decision. Thirty-eight respondents (32.48\%) moderately agreed that the selection of his/her student teaching site was solely his/her decision and 32 people $(27.35 \%)$ strongly agreed that the selection of his/her student teaching site was solely his/her decision (see Table 4). 
Seven respondents (5.98\%) strongly disagreed that he/she had input in the selection of his/her student teaching site. Of the respondents, five individuals (4.27\%) moderately disagreed that he/she had input in the selection of his/her student teaching site. Six individuals $(5.13 \%)$ slightly disagreed that he/she had input in the selection of his/her student teaching site. Fifteen participants (12.82\%) slightly agree that he/she had input in the selection of his/her student teaching site. Twenty-four individuals (20.51\%) moderately agreed and 60 participants (51.28\%) strongly agreed that he/she had input in the selection of his/her student teaching site (see Table 4). The median response was participants strongly agreed they had input in the selection of their student teaching site.

Nine individuals (7.69\%) strongly disagreed that university faculty influenced his/her student teaching site selection. Fourteen participants (11.97\%) moderately disagree that university faculty influenced his/her student teaching site selection. Eleven respondents $(9.40 \%)$ slightly disagree that university faculty influenced his/her student teaching site selection. Of the participants 40 individuals (34.19\%) slightly agreed that university faculty influenced his/her student teaching site selection. Twenty-five respondents (21.37\%) moderately agreed and 18 individuals (15.38\%) strongly agreed that university faculty influenced his/her student teaching site selection (see Table 4). The median response was individuals slightly agreed that university faculty influenced their student teaching site selection.

Twenty-three respondents (19.66\%) strongly disagreed with the statement "other people in the agricultural education profession influenced my student teaching site selection." Nine individuals (7.69\%) moderately disagreed that other people in the agricultural education profession influenced his/her student teaching site selection. 
Fourteen people (11.97\%) slightly disagreed and 36 individuals (30.77\%) slightly agreed other people in the agricultural education profession influenced his/her student teaching site selection. Twenty-seven respondents (23.08\%) moderately agreed and eight individuals $(6.84 \%)$ strongly agreed other people in the agricultural education profession influenced his/her student teaching site selection (see Table 4). The median response was individuals slightly agreed other people in the agricultural education profession influence their student teaching site selection.

Of the respondents, 12 people (10.34\%) strongly disagreed with the statement “my student teaching placement site was my first choice." Three respondents (2.59\%) moderately disagreed with the statement "my student teaching placement site was my first choice." Ten individuals (8.62\%) slightly disagreed that his/her student teaching site was his/her first choice. Five of the respondents (4.31\%) slightly agreed and ten individuals $(8.62 \%)$ moderately agreed with the statement "my student teaching placement site was my first choice." Of the participants, 76 respondents $(65.52 \%)$ moderately agreed that his/her student teaching placement site was his/her first choice (see Table 4). The respondents strongly agreed their student teaching placement site was their first choice (Median $=6$, strongly agree).

Twelve respondents (10.34\%) strongly disagreed and 11 individuals $(9.48 \%)$ moderately disagreed with the statement "I requested a student teaching site to match my strengths." Of the respondents, 16 individuals (13.79\%) slightly disagreed and 28 participants (24.14\%) slightly agreed that he/she requested a student teaching site to match his/her strengths. Twenty-three respondents (19.83\%) moderately agreed and 26 
individuals (22.41\%) strongly agree with the statement "I requested a student teaching site to match my strengths" (see Table 4). The median response was slightly agree.

Thirteen respondents (11.21\%) strongly disagreed that he/she requested a student teaching site to improve his/her weaknesses. Nine respondents (7.76\%) moderately disagreed with the statement "I requested a student teaching site to improve my weaknesses. Twenty-one participants (18.10\%) slightly disagreed and 31 individuals (26.72\%) slightly agreed he/she requested a student teaching site to improve his/her weaknesses. Twenty-four individuals (20.69\%) moderately agreed and 18 participants $(15.52 \%)$ strongly agreed he/she requested a student teaching site to improve his/her weaknesses (see Table 4). The median response was slightly agree.

Nineteen respondents (16.38\%) strongly disagreed with the statement "I requested a student teaching site based on the agriculture teacher there." Five individuals (4.31\%) moderately disagreed that he/she requested a student teaching site based on the agriculture teacher there. Eleven individuals (9.48\%) slightly disagreed and 26 respondents (22.41\%) slightly agreed he/she requested a student teaching site based on the agriculture teacher there. Of the participants, 28 individuals (24.14\%) moderately agreed and 27 respondents (23.28\%) strongly agreed that he/she requested a student teaching site based on the agriculture teacher there (see Table 4). The median response was slightly agree.

When asked to respond to the statement "I requested a student teaching site based on the facilities," 27 individuals (23.28\%) strongly disagreed, 15 people $(12.93 \%)$ moderately disagreed, and 15 individuals (12.93\%) slightly disagreed. Twenty-eight respondents (24.14\%) slightly agreed and 23 individuals (19.83\%) moderately agreed 
he/she requested a student teaching site based on the facilities. Eight respondents $(6.90 \%)$ strongly agreed with the statement "I requested a student teaching site based on the facilities" (see Table 4). The respondents slightly agreed (Median $=4$, slightly agree) they requested a student teaching site based on the facilities.

Participants were asked to respond to the statement "I requested a student teaching site based on the location of the school." Eight individuals (6.84\%) strongly disagreed, five people (4.27\%) moderately disagreed, and four individuals (3.42\%) slightly disagreed. Thirteen individuals (11.11\%) slightly agreed, 33 people (28.21\%) moderately agreed, and 54 respondents (46.15\%) strongly agreed. Respondents moderately agreed they requested a student teaching site based on the location of the school (Median $=5$, moderately agree).

Individuals were asked to rate their satisfaction with their student teaching placement site. Ten individuals (8.55\%) strongly disagreed, five people (4.27\%) moderately disagreed, and three respondents (2.56\%) slightly disagreed with the statements "I was satisfied with my student teaching placement site." Of the respondents, eight people (6.84\%) slightly agreed, eight (6.84\%) moderately agreed, and 83 individuals (70.94\%) strongly agreed he/she was satisfied with his/her student teaching placement site (see Table 4). The median response was strongly agree. 
Table 4

Factors Involved in the Student Teaching Site Selection for Individuals Who Completed a Student Teaching Experience

\begin{tabular}{|c|c|c|c|c|c|c|c|c|c|c|c|c|}
\hline & \multicolumn{2}{|c|}{$\begin{array}{l}\text { Strongly } \\
\text { Disagree }\end{array}$} & \multicolumn{2}{|c|}{$\begin{array}{l}\text { Moderately } \\
\text { Disagree }\end{array}$} & \multicolumn{2}{|c|}{$\begin{array}{l}\text { Slightly } \\
\text { Disagree }\end{array}$} & \multicolumn{2}{|c|}{$\begin{array}{l}\text { Slightly } \\
\text { Agree }\end{array}$} & \multicolumn{2}{|c|}{$\begin{array}{l}\text { Moderately } \\
\text { Agree }\end{array}$} & \multicolumn{2}{|c|}{$\begin{array}{l}\text { Strongly } \\
\text { Agree }\end{array}$} \\
\hline & $N$ & $\%$ & $N$ & $\%$ & $N$ & $\%$ & $N$ & $\%$ & $N$ & $\%$ & $N$ & $\%$ \\
\hline $\begin{array}{l}\text { The selection of my student teaching site was } \\
\text { solely my decision }\end{array}$ & 9 & 7.69 & 4 & 3.42 & 13 & 11.11 & 21 & 17.95 & 38 & 32.48 & 32 & 27.35 \\
\hline $\begin{array}{l}\text { I had input into the selection of my student } \\
\text { teaching site* }\end{array}$ & 7 & 5.98 & 5 & 4.27 & 6 & 5.13 & 15 & 12.82 & 24 & 20.51 & 60 & 51.28 \\
\hline $\begin{array}{l}\text { University faculty influenced my student } \\
\text { teaching site selection }\end{array}$ & 9 & 7.69 & 14 & 11.97 & 11 & 9.40 & 40 & 34.19 & 25 & 21.37 & 18 & 15.38 \\
\hline $\begin{array}{l}\text { Other people in the agricultural education } \\
\text { profession influenced my student teaching } \\
\text { selection site }\end{array}$ & 23 & 19.66 & 9 & 7.69 & 14 & 11.97 & 36 & 30.77 & 27 & 23.08 & 8 & 6.84 \\
\hline $\begin{array}{l}\text { My student teaching placement site was my first } \\
\text { choice }\end{array}$ & 12 & 10.34 & 3 & 2.59 & 10 & 8.62 & 5 & 4.31 & 10 & 8.62 & 76 & 65.52 \\
\hline $\begin{array}{l}\text { I requested a student teaching site to match my } \\
\text { strengths }\end{array}$ & 12 & 10.34 & 11 & 9.48 & 16 & 13.79 & 28 & 24.14 & 23 & 19.83 & 26 & 22.41 \\
\hline $\begin{array}{l}\text { I requested a student teaching site to improve } \\
\text { my weaknesses }\end{array}$ & 13 & 11.21 & 9 & 7.76 & 21 & 18.10 & 31 & 26.72 & 24 & 20.69 & 18 & 15.52 \\
\hline $\begin{array}{l}\text { I requested a student teaching site based on the } \\
\text { agriculture teacher there }\end{array}$ & 19 & 16.38 & 5 & 4.31 & 11 & 9.48 & 26 & 22.41 & 28 & 24.14 & 27 & 23.28 \\
\hline $\begin{array}{l}\text { I requested a student teaching site based on the } \\
\text { facilities }\end{array}$ & 27 & 23.28 & 15 & 12.93 & 15 & 12.93 & 28 & 24.14 & 23 & 19.83 & 8 & 6.90 \\
\hline
\end{tabular}


Table 4 (Continued)

Factors Involved in the Student Teaching Site Selection for Individuals Who Completed a Student Teaching Experience

\begin{tabular}{|c|c|c|c|c|c|c|c|c|c|c|c|c|}
\hline & \multicolumn{2}{|c|}{$\begin{array}{l}\text { Strongly } \\
\text { Disagree }\end{array}$} & \multicolumn{2}{|c|}{$\begin{array}{l}\text { Moderately } \\
\text { Disagree }\end{array}$} & \multicolumn{2}{|c|}{$\begin{array}{l}\text { Slightly } \\
\text { Disagree }\end{array}$} & \multicolumn{2}{|c|}{$\begin{array}{l}\text { Slightly } \\
\text { Agree }\end{array}$} & \multicolumn{2}{|c|}{$\begin{array}{l}\text { Moderately } \\
\text { Agree }\end{array}$} & \multicolumn{2}{|c|}{$\begin{array}{l}\text { Strongly } \\
\text { Agree }\end{array}$} \\
\hline & $N$ & $\%$ & $N$ & $\%$ & $N$ & $\%$ & $N$ & $\%$ & $N$ & $\%$ & $N$ & $\%$ \\
\hline $\begin{array}{l}\text { I requested a student teaching site based on the } \\
\text { location of the school }\end{array}$ & 8 & 6.84 & 5 & 4.27 & 4 & 3.42 & 13 & 11.11 & 33 & 28.21 & 54 & 46.15 \\
\hline $\begin{array}{l}\text { I was satisfied with my student teaching } \\
\text { placement site* }\end{array}$ & 10 & 8.55 & 5 & 4.27 & 3 & 2.56 & 8 & 6.84 & 8 & 6.84 & 83 & 70.94 \\
\hline
\end{tabular}

*Reverse Coded for data analysis. 


\section{Role of Cooperating Teachers during Student Teaching}

Participants responded to questions regarding their cooperating teacher during the student teaching experience. This section consisted of 17 Likert type statements. Answer options included strongly disagree, moderately disagree, slightly disagree, slightly agree, moderately agree, and strongly agree.

Responses to the statement "my cooperating teacher introduced my credentials to help establish my rapport with the students" included six individuals (5.13\%) who strongly disagreed, four respondents $(3.42 \%)$ who moderately disagreed, and five people (4.27\%) who slightly disagreed. Twenty respondents (17.09\%) slightly agreed, 40 people (34.19\%) moderately agreed, and 42 people (35.90\%) strongly agreed that his/her cooperating teacher introduced his/her credentials to help establish his/her rapport with the students (see Table 5). The median response was moderately agree.

Four individuals (3.42\%) strongly disagreed, four people (3.42\%) moderately disagreed, and four respondents (3.42\%) slightly disagreed that his/her cooperating teacher was readily available to answer his/her questions. Of the respondents, five individuals (4.27\%) slightly agreed, 22 people (18.80\%) moderately agreed, and 78 respondents $(66.67 \%)$ strongly agreed with the statement "my cooperating teacher was readily available to answer my questions" (see Table 5). The respondents strongly agreed their cooperating teacher was readily available to answer their questions (Median $=6$, strongly agree).

When asked to respond to the statement "my cooperating teacher supported my decisions in front of students," five individuals (4.27\%) strongly disagreed, two people (1.71\%) slightly disagreed, 11 individuals $(9.40 \%)$ slightly agreed, 15 respondents 
(12.82\%) moderately agreed, and 84 people (71.79\%) strongly agreed (see Table 5). The median response was strongly agree.

Two people (1.71\%) strongly disagreed and five individuals (4.27\%) moderately disagreed his/her cooperating teacher was willing to help her/him in any way possible. Six respondents (5.13\%) slightly disagreed and six individuals (5.13\%) slightly agreed with the statement "my cooperating teacher was willing to help me in any way possible." Of the respondents, 15 individuals (12.82\%) moderately agreed and 83 people (70.94\%) strongly agreed his/her cooperating teacher was willing to help him/her in any way possible (see Table 5). The median response was strongly agree.

Seventeen participants (14.78\%) strongly disagreed his/her cooperating teacher provided him/her with adequate guidance. Nine people (7.83\%) moderately disagreed his/her cooperating teacher provided him/her with adequate guidance. Twenty-four people (20.87\%) slightly disagreed his/her cooperating teacher provided him/her with adequate guidance. Of the participants, 13 people (11.30\%) slightly agreed, 24 individuals (20.87\%) moderately agreed, and 28 participants (24.35\%) strongly agreed his/her cooperating teacher provided him/her with adequate guidance (see Table 5). The respondents slightly agree that their cooperating teacher provided them with adequate guidance (Median $=4$, slightly agree).

Nine respondents $(7.69 \%)$ strongly disagreed, 11 individuals moderately disagreed, and nine individuals (7.69\%) slightly disagreed his/her cooperating teacher evaluated his/her performance each week. Twenty-three respondents (19.66\%) slightly agreed, 30 people (25.64\%) moderately agreed, and 35 individuals (29.91\%) strongly 
agreed with the statement "my cooperating teacher evaluated my performance each week" (see Table 5). The median response was moderately agree.

In response to the statement "my cooperating teacher encouraged me to go with him/her and students to FFA events and activities," three individuals (2.56\%) strongly disagreed, two people (1.71\%) moderately disagreed, and two people (1.71\%) slightly disagreed. Of the respondents, eight individuals (6.84\%) slightly agreed, 17 people (14.53\%) moderately agreed, and 85 individuals (72.65\%) strongly agreed (see Table 5). The median response was strongly agree.

Three individuals (2.56\%) strongly disagreed that his/her cooperating teacher provided feedback about his/her progress during student teaching. Four respondents (3.42\%) moderately disagreed and ten respondents (8.55\%) slightly disagreed with the statement "my cooperating teacher provided feedback about my progress during student teaching." Sixteen individuals (13.68\%) slightly agreed, 26 people $(22.22 \%)$ moderately agreed, and 58 respondents (49.57\%) strongly agreed with the statement (see Table 5). The median response was moderately agree.

The opinions of the respondents were they strongly agreed their cooperating teacher had a positive attitude toward teaching (Median $=6$, strongly agree). Four respondents (3.42\%) strongly disagreed that his/her cooperating teacher had a positive attitude toward teaching. One individual (.85\%) moderately disagreed, nine people (7.69\%) slightly disagreed, and six people (5.13\%) slightly agreed his/her cooperating teacher had a positive attitude toward teaching. Of the respondents, 18 individuals (15.38\%) moderately agreed and 79 respondents (67.52\%) strongly agreed with the statement "my cooperating teacher had a positive attitude toward teaching (see Table 5). 
In response to the statement "my cooperating teacher had a positive attitude toward students," two individuals (1.71\%) strongly disagreed, seven people (5.98\%) slightly disagreed, and seven people (5.98\%) slightly agreed. Twenty-four individuals (20.51\%) moderately agreed and 77 people $(65.81 \%)$ strongly agreed his/her cooperating teacher had a positive attitude toward students (see Table 5). The median response was strongly agree.

Three individuals (2.56\%) strongly disagreed, one person moderately disagreed, and two respondents $(1.71 \%)$ slightly disagreed his/her cooperating teacher had a positive attitude toward the agricultural education profession. Of the participants, ten individuals (8.55\%) slightly agreed, 18 people (15.83\%) moderately agreed, and 83 individuals (70.94\%) strongly agreed with the statement "my cooperating teacher had a positive attitude toward the agricultural education profession" (see Table 5). The median response was strongly agree.

Six people (5.13\%) strongly disagreed, five people (4.27\%) moderately disagreed, and six people (5.21\%) slightly disagreed his/her cooperating teacher created a good working atmosphere. Of the respondents, four individuals (3.42\%) slightly agreed, 18 individuals (15.38\%) moderately agreed, and 78 individuals (66.67\%) strongly agreed with the statement "my cooperating teacher created a good working atmosphere" (see Table 5). The respondents strongly agreed their cooperating teacher created a good working atmosphere (Median $=6$, strongly agree).

Of the individuals who responded to the statement "I was permitted to miss school to travel with my cooperating teacher to professional meetings," four individuals (3.67\%) strongly disagreed, one person (.92\%) moderately disagreed, and five people 
(4.59\%) slightly disagreed. Nine individuals (8.26\%) slightly agreed, 14 people (12.84\%) moderately agreed, and 76 individuals (69.72\%) strongly agreed that he/she was permitted to miss school to travel with his/her cooperating teacher to professional meetings (see Table 5). The median response was strongly agree.

Twelve respondents (10.53\%) strongly disagreed, seven individuals (6.14\%) moderately disagreed, and 14 people (12.28\%) slightly disagree that his/her cooperating teacher gave him/her guidance regarding SAE visits. Twelve individuals (10.53\%) slightly agreed, 24 people (21.05\%) moderately agreed, and 45 people (39.47\%) strongly agreed with the statement "my cooperating teacher gave him/her guidance regarding SAE visits" (see Table 5). The median response was moderately agree.

Four respondents (3.42\%) strongly disagreed that he/she had a positive relationship with his/her cooperating teacher. Six people (5.13\%) moderately disagreed and two individuals (1.71\%) slightly disagreed with the statement "I had a positive relationship with my cooperating teacher.” Six individuals (5.13\%) slightly agreed, 14 people (11.97\%) moderately agreed, and 85 individuals (72.75\%) strongly agreed that he/she had a positive relationship with his/her cooperating teacher (see Table 5). The respondents strongly agreed they had a positive relationship with their cooperating teaching (Median $=6$, strongly agree).

Five people (4.27\%) strongly disagreed, three people (2.56\%) moderately disagreed, and ten individuals (8.55\%) slightly disagreed that his/her cooperating teacher helped him/her with discipline issues. Of the respondents, 10 people $(8.55 \%)$ slightly agreed, 25 individuals (21.37\%) moderately agreed, and 64 people (54.70\%) strongly 
agreed with the statement "My cooperating teacher helped me with discipline issues" (see Table 5). The median response was strongly agree.

When asked to respond to the statement "my cooperating teacher and university supervisor discussed my progress," one individual (.86\%) strongly disagreed, two individuals (1.72\%) moderately disagreed, and two individuals (1.72\%) slightly disagreed. Twelve people (10.34\%) slightly agreed, 33 people $(28.45 \%)$ moderately agreed, and 66 people (56.90\%) strongly agreed that his/her cooperating teacher and university supervisor discussed his/her progress (see Table 5). The median response was strongly agree.

Role of the University Supervisors during Student Teaching

Participants were asked to respond to statements regarding their university supervisor(s) during their student teaching experience. This section consisted of six Likert items, and answer options included strongly disagree, moderately disagree, slightly disagree, slightly agree, moderately agree, and strongly agree.

In response to the statement "my university supervisor provided constructive feedback," two respondents (1.71\%) strongly disagreed, five individuals (4.27\%) moderately disagreed, and three people (2.56\%) slightly disagreed. Eleven individuals (9.40\%) slightly agreed, 23 people (19.66\%) moderately agreed, and 73 people $(62.39 \%)$ strongly agreed that his/her university supervisor provided constructive feedback (see Table 6). The respondents strongly agreed their university supervisor provided constructive feedback (Median $=6$, strongly agree) . 
Table 5

Role of Cooperating Teachers during Student Teaching

\begin{tabular}{|c|c|c|c|c|c|c|c|c|c|c|c|c|}
\hline & \multicolumn{2}{|c|}{$\begin{array}{l}\text { Strongly } \\
\text { Disagree }\end{array}$} & \multicolumn{2}{|c|}{$\begin{array}{l}\text { Moderately } \\
\text { Disagree }\end{array}$} & \multicolumn{2}{|c|}{$\begin{array}{l}\text { Slightly } \\
\text { Disagree }\end{array}$} & \multicolumn{2}{|c|}{$\begin{array}{l}\text { Slightly } \\
\text { Agree }\end{array}$} & \multicolumn{2}{|c|}{$\begin{array}{l}\text { Moderately } \\
\text { Agree }\end{array}$} & \multicolumn{2}{|c|}{$\begin{array}{l}\text { Strongly } \\
\text { Agree }\end{array}$} \\
\hline & $N$ & $\%$ & $N$ & $\%$ & $N$ & $\%$ & $N$ & $\%$ & $N$ & $\%$ & $N$ & $\%$ \\
\hline $\begin{array}{l}\text { My cooperating teacher introduced my } \\
\text { credentials to help establish my rapport with the } \\
\text { students }\end{array}$ & 6 & 5.13 & 4 & 3.42 & 5 & 4.27 & 20 & 17.09 & 40 & 34.19 & 42 & 35.90 \\
\hline $\begin{array}{l}\text { My cooperating teacher was readily available to } \\
\text { answer my questions }\end{array}$ & 4 & 3.42 & 4 & 3.42 & 4 & 3.42 & 5 & 4.27 & 22 & 18.80 & 78 & 66.67 \\
\hline $\begin{array}{l}\text { My cooperating teacher supported my decisions } \\
\text { in front of students }\end{array}$ & 5 & 4.27 & 0 & 0.00 & 2 & 1.71 & 11 & 9.40 & 15 & 12.82 & 84 & 71.79 \\
\hline $\begin{array}{l}\text { My cooperating teacher was willing to help me } \\
\text { in any way possible }\end{array}$ & 2 & 1.71 & 5 & 4.27 & 6 & 5.13 & 6 & 5.13 & 15 & 12.82 & 83 & 70.94 \\
\hline $\begin{array}{l}\text { My cooperating teacher provided me with } \\
\text { adequate guidance* }\end{array}$ & 17 & 14.78 & 9 & 7.83 & 24 & 20.87 & 13 & 11.30 & 24 & 20.87 & 28 & 24.35 \\
\hline $\begin{array}{l}\text { My cooperating teacher evaluated my } \\
\text { performance each week }\end{array}$ & 9 & 7.69 & 11 & 9.40 & 9 & 7.69 & 23 & 19.66 & 30 & 25.64 & 35 & 29.91 \\
\hline $\begin{array}{l}\text { My cooperating teacher encouraged me to go } \\
\text { with him/her and students to FFA events and } \\
\text { activities }\end{array}$ & 3 & 2.56 & 2 & 1.71 & 2 & 1.71 & 8 & 6.84 & 17 & 14.53 & 85 & 72.65 \\
\hline $\begin{array}{l}\text { My cooperating teacher provided feedback } \\
\text { about my progress during student teaching }\end{array}$ & 3 & 2.56 & 4 & 3.42 & 10 & 8.55 & 16 & 13.68 & 26 & 22.22 & 58 & 49.57 \\
\hline
\end{tabular}


Table 5 (Continued)

Role of Cooperating Teachers during Student Teaching

\begin{tabular}{|c|c|c|c|c|c|c|c|c|c|c|c|c|}
\hline & \multicolumn{2}{|c|}{$\begin{array}{l}\text { Strongly } \\
\text { Disagree }\end{array}$} & \multicolumn{2}{|c|}{$\begin{array}{l}\text { Moderately } \\
\text { Disagree }\end{array}$} & \multicolumn{2}{|c|}{$\begin{array}{l}\text { Slightly } \\
\text { Disagree }\end{array}$} & \multicolumn{2}{|c|}{$\begin{array}{l}\text { Slightly } \\
\text { Agree }\end{array}$} & \multicolumn{2}{|c|}{$\begin{array}{l}\text { Moderately } \\
\text { Agree }\end{array}$} & \multicolumn{2}{|c|}{$\begin{array}{l}\text { Strongly } \\
\text { Agree }\end{array}$} \\
\hline & $N$ & $\%$ & $N$ & $\%$ & $N$ & $\%$ & $N$ & $\%$ & $N$ & $\%$ & $N$ & $\%$ \\
\hline $\begin{array}{l}\text { My cooperating teacher had a positive attitude } \\
\text { toward teaching }\end{array}$ & 4 & 3.42 & 1 & .85 & 9 & 7.69 & 6 & 5.13 & 18 & 15.38 & 79 & 67.52 \\
\hline $\begin{array}{l}\text { My cooperating teacher had a positive attitude } \\
\text { toward students }\end{array}$ & 2 & 1.71 & 0 & 0.00 & 7 & 5.98 & 7 & 5.98 & 24 & 20.51 & 77 & 65.81 \\
\hline $\begin{array}{l}\text { My cooperating teacher had a positive attitude } \\
\text { toward the agricultural education profession }\end{array}$ & 3 & 2.56 & 1 & .85 & 2 & 1.71 & 10 & 8.55 & 18 & 15.38 & 83 & 70.94 \\
\hline $\begin{array}{l}\text { My cooperating teacher created a good working } \\
\text { atmosphere }\end{array}$ & 6 & 5.13 & 5 & 4.27 & 6 & 5.13 & 4 & 3.42 & 18 & 15.38 & 78 & 66.67 \\
\hline $\begin{array}{l}\text { I was permitted to miss school to travel with my } \\
\text { cooperating teacher to professional meetings }\end{array}$ & 4 & 3.67 & 1 & .92 & 5 & 4.59 & 9 & 8.26 & 14 & 12.84 & 76 & 69.72 \\
\hline $\begin{array}{l}\text { My cooperating teacher gave me guidance } \\
\text { regarding SAE visits* }\end{array}$ & 12 & 10.53 & 7 & 6.14 & 14 & 12.28 & 12 & 10.53 & 24 & 21.05 & 45 & 39.47 \\
\hline $\begin{array}{l}\text { I had a positive relationship with my } \\
\text { cooperating teacher }\end{array}$ & 4 & 3.42 & 6 & 5.13 & 2 & 1.71 & 6 & 5.13 & 14 & 11.97 & 85 & 72.65 \\
\hline $\begin{array}{l}\text { My cooperating teacher helped me with } \\
\text { discipline issues }\end{array}$ & 5 & 4.27 & 3 & 2.56 & 10 & 8.55 & 10 & 8.55 & 25 & 21.37 & 64 & 54.70 \\
\hline $\begin{array}{l}\text { My cooperating teacher and university } \\
\text { supervisor discussed my progress }\end{array}$ & 1 & .86 & 2 & 1.72 & 2 & 1.72 & 12 & 10.34 & 33 & 28.45 & 66 & 56.90 \\
\hline
\end{tabular}

*Reverse coded for data analysis 
One respondent (.85\%) strongly disagreed, two respondents (1.71\%) moderately disagreed, and three respondents (2.56\%) slightly disagreed his/her university supervisor provided positive feedback. Nine individuals (7.69\%) slightly agreed, 27 people (23.08\%) moderately agreed, and 75 respondents $(64.10 \%)$ strongly agreed that his/her university supervisor provided positive feedback (see Table 6). The median response was the participants strongly agreed their university supervisor provided positive feedback (Median $=6$, strongly agree).

One respondent (.85\%) strongly disagreed, two respondents (1.71\%) moderately disagreed, and four individuals (3.42\%) slightly agreed with the statement "My university supervisor offered suggestions for improving my teaching techniques." Thirteen individuals (11.11\%) slightly agreed, 32 people (27.35\%) moderately agreed, and 65 individuals (55.56\%) strongly agreed that his/her university supervisor offered suggestions for improving his/her teaching techniques (see Table 6). The median response was strongly agree.

In response to the statement "my university supervisor created a positive atmosphere during his/her visits," two individuals (1.71\%) strongly disagreed, five people (4.27\%) moderately disagreed, and three people (2.56\%) slightly disagreed. Nine people $(7.69 \%)$ slightly agreed, 13 people $(11.11 \%)$ moderately agreed, and 84 people (71.79\%) strongly agreed that his/her university supervisor created a positive atmosphere during his/her visits (see Table 6). The median response was strongly agree.

The respondents strongly agreed they had a positive relationship with their university supervisor (Median $=6$, strongly agree). Three people (2.56\%) strongly disagreed, five individuals (4.27\%) moderately disagreed, and three people (2.56\%) 
slightly disagreed he/she had a positive relationship with his/her university supervisor. Of the respondents, nine individuals (7.69\%) slightly agreed, 13 people (11.11\%) moderately agreed, and 84 respondents $(71.79 \%)$ strongly agreed he/she had a positive relationship with his/her university supervisor (see Table 6).

When asked to respond to the statement "my university supervisor made me aware he/she was available in any way to help me have a good student teaching experience," two individuals (1.71\%) strongly disagreed, three individuals (2.56\%) moderately disagreed, and nine people (7.69\%) slightly disagreed. Thirteen people (11.11\%) slightly agreed, 26 individuals (22.22\%) moderately agreed, and 64 people (54.70\%) strongly agreed his/her university supervisor made him/her aware he/she was available in any way to help me have a good student teaching experience (see Table 6). The median response was strongly agree.

\section{School and Community Support during Student Teaching}

Participants were presented with two Likert type statements regarding school and community support they received during student teaching. Answer options included strongly disagree, moderately disagree, slightly disagree, slightly agree, moderately agree, and strongly agree. 
Table 6

Role of the University Supervisor during Student Teaching

\begin{tabular}{|c|c|c|c|c|c|c|c|c|c|c|c|c|}
\hline & \multicolumn{2}{|c|}{$\begin{array}{l}\text { Strongly } \\
\text { Disagree }\end{array}$} & \multicolumn{2}{|c|}{$\begin{array}{l}\text { Moderately } \\
\text { Disagree }\end{array}$} & \multicolumn{2}{|c|}{$\begin{array}{l}\text { Slightly } \\
\text { Disagree }\end{array}$} & \multicolumn{4}{|c|}{$\begin{array}{l}\text { Moderately } \\
\text { Agree }\end{array}$} & \multicolumn{2}{|c|}{ Strongly Agree } \\
\hline & $N$ & $\%$ & $N$ & $\%$ & $N$ & $\%$ & $N$ & $\%$ & $N$ & $\%$ & $N$ & $\%$ \\
\hline $\begin{array}{l}\text { My university supervisor provided } \\
\text { constructive feedback }\end{array}$ & 2 & 1.71 & 5 & 4.27 & 3 & 2.56 & 11 & 9.40 & 23 & 19.66 & 73 & 62.39 \\
\hline $\begin{array}{l}\text { My university supervisor provided } \\
\text { positive feedback }\end{array}$ & 1 & .85 & 2 & 1.71 & 3 & 2.56 & 9 & 7.69 & 27 & 23.08 & 75 & 64.10 \\
\hline $\begin{array}{l}\text { My university supervisor offered } \\
\text { suggestions for improving my teaching } \\
\text { techniques }\end{array}$ & 1 & .85 & 2 & 1.71 & 4 & 3.42 & 13 & 11.11 & 32 & 27.35 & 65 & 55.56 \\
\hline $\begin{array}{l}\text { My university supervisor created a } \\
\text { positive atmosphere during his her visits }\end{array}$ & 2 & 1.71 & 5 & 4.27 & 5 & 4.27 & 8 & 6.84 & 26 & 22.22 & 71 & 60.68 \\
\hline $\begin{array}{l}\text { I had a positive relationship with my } \\
\text { university supervisor* }\end{array}$ & 3 & 2.56 & 5 & 4.27 & 3 & 2.56 & 9 & 7.69 & 13 & 11.11 & 84 & 71.79 \\
\hline $\begin{array}{l}\text { My university supervisor made me aware } \\
\text { he/she was available in any way to help } \\
\text { me have a good student teaching } \\
\text { experience }\end{array}$ & 2 & 1.71 & 3 & 2.56 & 9 & 7.69 & 13 & 11.11 & 26 & 22.22 & 64 & 54.70 \\
\hline
\end{tabular}

*Reverse coded for data analysis 
In response to the statement "the school administration was supportive of my presence," three respondents $(2.59 \%)$ slightly disagreed, 22 people (18.97\%) slightly agreed, 31 people $(26.72 \%)$ moderately agreed and 60 individuals $(51.72 \%)$ strongly agreed. The median response was strongly agree. One individual $(.86 \%)$ moderately disagreed, five people (4.31\%) slightly disagreed, 20 people (17.24\%) slightly agreed, 30 individuals $(25.86 \%)$ moderately agreed, and 60 individuals $(51.72 \%)$ strongly agreed the community supported him/her during his/her student teaching experience (see Table 7). The median response was strongly agree.

\section{Classroom and Laboratory Experiences during Student Teaching}

Participants were asked to respond to five Likert type statements about their classroom and laboratory experiences during student teaching. Six participants $(5.17 \%)$ strongly disagreed they did not have major discipline problems. Of the participants, 14 people $(12.07 \%)$ moderately disagreed they did not have major discipline issues. Six individuals (5.17\%) slightly disagreed, 22 people (18.97\%) slightly agreed, and 35 individuals (30.17\%) moderately agreed with the statement "I did not have major discipline issues." Thirty-three individuals (28.45\%) strongly agreed they did not have major discipline issues during student teaching (see Table 8). The median response was moderately agree.

One respondent (.86\%) strongly disagreed and one respondent (.86\%) moderately disagreed he/she was able to handle discipline issues. Two individuals (1.72\%) slightly disagreed and 17 individuals (14.66\%) slightly agreed he/she was able to handle discipline issues. Fifty-one people (43.97\%) moderately agreed and 44 people $(37.93 \%)$ 
strongly agreed he/she was able to handle discipline issues (see Table 8). The median response was moderately agree.

Of the participants who completed a response to the statement "I maintained adequate classroom control," one participant (.88\%) strongly disagreed, one individual $(.88 \%)$ moderately disagreed, and one individual (.88\%) slightly disagreed. Eight respondents (7.02\%) slightly agreed, 62 people (54.39\%) moderately agreed, and 41 individuals (35.96\%) strongly agreed that they maintained adequate classroom control (see Table 8). The median response was slightly agree.

Two respondents (1.74\%) strongly disagreed, five people $(4.35 \%)$ moderately disagreed, and 11 people (9.57\%) slightly disagreed he/she felt confident with his/her ability to teach in a laboratory setting. Thirteen individuals $(11.30 \%)$ slightly agreed, 45 people (39.13\%) moderately agreed, and 39 individuals (33.91\%) strongly agreed with the statement "I felt confident in my ability to teach in a laboratory setting" (see Table 8). The median response was moderately agree.

Respondents moderately agreed their students appeared to respond to their teaching methods (Median $=5$, moderately agree). One individual $(.86 \%)$ strongly disagreed, two people (1.72\%) moderately disagreed, and one individual (.86\%) slightly disagreed students appeared to respond to his/her teaching methods. Eighteen people (15.52\%) slightly agreed, 61 people (52.59\%) moderately agreed, and 33 people $(28.45 \%)$ strongly agreed students appeared to respond to his/her teaching methods (see Table 8). The median response was moderately agree. 


\section{Role with FFA Activities during Student Teaching}

Respondents were asked about their role with FFA activities while student teaching and the section included two Likert type statements. One individual (.85\%) strongly disagreed, four people $(3.42 \%)$ moderately disagreed, and four people $(3.42 \%)$ slightly disagreed he/she frequently helped with FFA activities outside of school hours. Eight people (6.84\%) slightly agreed, 17 people (14.66\%) moderately agreed, and 76 individuals (65.52\%) strongly agreed he/she frequently helped with FFA activities outside of school hours (see Table 9). The median response was strongly agree.

Of the individuals who responded to the statement "I trained teams for FFA contests," 12 respondents (10.34\%) strongly disagreed, four people (3.45\%) moderately disagreed, and one individual (.86\%) slightly disagreed. Six respondents (5.17\%) slightly agreed, 25 people $(21.37 \%)$ moderately agreed, and 75 participants $(64.10 \%)$ strongly

agreed (see Table 9). The respondents strongly agreed they trained teams for FFA contests (Median $=6$, strongly agree).

\section{Stages of Participants’ Decision to Teach Agriculture}

Participants were asked to respond to four Likert type statements about the stage at which they wanted to teach agriculture. Thirty-seven individuals (31.62\%) strongly disagreed with the statement "I wanted to teach agriculture when I started college." Thirteen people (11.11\%) moderately disagreed and eight individuals (6.84\%) slightly disagreed he/she wanted to teach agriculture when he/she started college. Four people (3.42\%) slightly agreed, eight people (6.84\%) moderately agreed, and 33 individuals $(28.45 \%)$ strongly agreed he/she wanted to teach agriculture when he/she started college 
(see Table 10). The respondents slightly agreed they wanted to teach agriculture when they started college (Median $=4$, slightly agree $)$.

Ten people (8.62\%) strongly disagreed, five individuals (4.31\%) moderately disagreed, and eight individuals (6.90\%) slightly disagreed he/she wanted to teach agriculture before enrolling in teaching methods. Eight individuals (6.90\%) slightly agreed, 19 respondents (16.38\%) moderately agreed, and 66 individuals $(56.90 \%)$ strongly agreed he/she wanted to teach agriculture before enrolling in teaching methods (see Table 10). The median response was strongly agree.

Respondents were asked to respond to the statement "I wanted to teach agriculture before my student teaching experience." Six people (5.13\%) strongly disagreed, two people (1.71\%) moderately disagreed, six people (5.13\%) slightly disagreed, nine people (7.69\%) slightly agreed, 19 people (16.24\%) moderately agreed, and 75 individuals (64.10\%) strongly agreed that he/she wanted to teach agriculture before the student teaching experience (see Table 10). The respondents strongly agreed they wanted to teach agriculture before their student teaching experience (Median $=6$, strongly agree).

Seven individuals (6.03\%) strongly disagreed and three respondents (2.59\%) moderately disagreed he/she wanted to teach agriculture after his/her student teaching experience. Twelve people (10.34\%) slightly disagreed and three individuals (2.59\%) slightly agreed they wanted to teach agriculture after their student teaching experience. Fifteen participants (12.93\%) moderately agreed and 76 individuals $(65.52 \%)$ strongly agreed he/she wanted to teach agriculture after his/her student teaching experience (see Table 10). The respondents strongly agreed they wanted to teach agriculture after their student teaching experience (Median $=6$, strongly agree). 
Table 7

School and Community Support Encountered by Individuals who Completed a Student Teaching Experience

\begin{tabular}{|c|c|c|c|c|c|c|c|c|c|c|c|c|}
\hline & \multicolumn{2}{|c|}{$\begin{array}{l}\text { Strongly } \\
\text { Disagree }\end{array}$} & \multicolumn{2}{|c|}{$\begin{array}{l}\text { Moderately } \\
\text { Disagree }\end{array}$} & \multicolumn{2}{|c|}{$\begin{array}{l}\text { Slightly } \\
\text { Disagree }\end{array}$} & \multicolumn{2}{|c|}{ Slightly Agree } & \multicolumn{2}{|c|}{$\begin{array}{l}\text { Moderately } \\
\text { Agree }\end{array}$} & \multicolumn{2}{|c|}{ Strongly Agree } \\
\hline & $N$ & $\%$ & $N$ & $\%$ & $N$ & $\%$ & $N$ & $\%$ & $N$ & $\%$ & $N$ & $\%$ \\
\hline $\begin{array}{l}\text { The school administration was } \\
\text { supportive of my presence }\end{array}$ & 0 & 0.00 & 0 & 0.00 & 3 & 2.59 & 22 & 18.97 & 31 & 26.72 & 60 & 51.72 \\
\hline $\begin{array}{l}\text { The community supported me during } \\
\text { my student teaching experience }\end{array}$ & 0 & 0.00 & 1 & .86 & 5 & 4.31 & 20 & 17.24 & 30 & 25.86 & 60 & 51.72 \\
\hline
\end{tabular}


Table 8

Classroom and Laboratory Experiences of Individuals who Completed a Student Teaching Experience

\begin{tabular}{|c|c|c|c|c|c|c|c|c|c|c|c|c|}
\hline & \multicolumn{2}{|c|}{$\begin{array}{l}\text { Strongly } \\
\text { Disagree }\end{array}$} & \multicolumn{2}{|c|}{$\begin{array}{l}\text { Moderately } \\
\text { Disagree }\end{array}$} & \multicolumn{2}{|c|}{$\begin{array}{l}\text { Slightly } \\
\text { Disagree }\end{array}$} & \multicolumn{2}{|c|}{ Slightly Agree } & \multicolumn{2}{|c|}{$\begin{array}{l}\text { Moderately } \\
\text { Agree }\end{array}$} & \multicolumn{2}{|c|}{ Strongly Agree } \\
\hline & $N$ & $\%$ & $N$ & $\%$ & $N$ & $\%$ & $N$ & $\%$ & $N$ & $\%$ & $N$ & $\%$ \\
\hline $\begin{array}{l}\text { I did not have major discipline } \\
\text { problems }\end{array}$ & 6 & 5.17 & 14 & 12.07 & 6 & 5.17 & 22 & 18.97 & 35 & 30.17 & 33 & 28.45 \\
\hline I was able to handle discipline issues & 1 & .86 & 1 & .86 & 2 & 1.72 & 17 & 14.66 & 51 & 43.97 & 44 & 37.93 \\
\hline $\begin{array}{l}\text { I maintained adequate classroom } \\
\text { control }\end{array}$ & 1 & .88 & 1 & .88 & 1 & .88 & 8 & 7.02 & 62 & 54.39 & 41 & 35.96 \\
\hline $\begin{array}{l}\text { I felt confident in my ability to teach } \\
\text { in a laboratory setting* }\end{array}$ & 2 & 1.74 & 5 & 4.35 & 11 & 9.57 & 13 & 11.30 & 45 & 39.13 & 39 & 33.91 \\
\hline $\begin{array}{l}\text { Students appeared to respond to my } \\
\text { teaching methods }\end{array}$ & 1 & .86 & 2 & 1.72 & 1 & .86 & 18 & 15.52 & 61 & 52.59 & 33 & 28.45 \\
\hline
\end{tabular}

*Reverse coded for data analysis 
Table 9

Involvement in FFA Activities during Student Teaching

\begin{tabular}{|c|c|c|c|c|c|c|c|c|c|c|c|c|}
\hline & \multicolumn{2}{|c|}{$\begin{array}{l}\text { Strongly } \\
\text { Disagree }\end{array}$} & \multicolumn{2}{|c|}{$\begin{array}{l}\text { Moderately } \\
\text { Disagree }\end{array}$} & \multicolumn{2}{|c|}{$\begin{array}{l}\text { Slightly } \\
\text { Disagree }\end{array}$} & \multicolumn{2}{|c|}{ Slightly Agree } & \multicolumn{2}{|c|}{$\begin{array}{l}\text { Moderately } \\
\text { Agree }\end{array}$} & \multicolumn{2}{|c|}{ Strongly Agree } \\
\hline & $N$ & $\%$ & $N$ & $\%$ & $N$ & $\%$ & $N$ & $\%$ & $N$ & $\%$ & $N$ & $\%$ \\
\hline $\begin{array}{l}\text { I frequently helped with FFA } \\
\text { activities outside of school hours }\end{array}$ & 1 & .85 & 4 & 3.42 & 4 & 3.42 & 8 & 6.84 & 25 & 21.37 & 75 & 64.10 \\
\hline I trained teams for FFA contests* & 12 & 10.34 & 4 & 3.45 & 1 & .86 & 6 & 5.17 & 17 & 14.66 & 76 & 65.52 \\
\hline
\end{tabular}


Table 10

Stages of Respondents' Decision to Teach Agriculture

\begin{tabular}{|c|c|c|c|c|c|c|c|c|c|c|c|c|}
\hline & \multicolumn{2}{|c|}{$\begin{array}{l}\text { Strongly } \\
\text { Disagree }\end{array}$} & \multicolumn{2}{|c|}{$\begin{array}{l}\text { Moderately } \\
\text { Disagree }\end{array}$} & \multicolumn{2}{|c|}{$\begin{array}{l}\text { Slightly } \\
\text { Disagree }\end{array}$} & \multicolumn{2}{|c|}{ Slightly Agree } & \multicolumn{2}{|c|}{$\begin{array}{l}\text { Moderately } \\
\text { Agree }\end{array}$} & \multicolumn{2}{|c|}{ Strongly Agree } \\
\hline & $N$ & $\%$ & $N$ & $\%$ & $N$ & $\%$ & $N$ & $\%$ & $N$ & $\%$ & $N$ & $\%$ \\
\hline $\begin{array}{l}\text { I wanted to teach agriculture when I } \\
\text { started college }\end{array}$ & 37 & 31.62 & 13 & 11.11 & 8 & 6.84 & 4 & 3.42 & 8 & 6.84 & 47 & 40.17 \\
\hline $\begin{array}{l}\text { I wanted to teach agriculture before I } \\
\text { enrolled in teaching methods }\end{array}$ & 10 & 8.62 & 5 & 4.31 & 8 & 6.90 & 8 & 6.90 & 19 & 16.38 & 66 & 56.90 \\
\hline $\begin{array}{l}\text { I wanted to teach agriculture before } \\
\text { my student teaching experience }\end{array}$ & 6 & 5.13 & 2 & 1.71 & 6 & 5.13 & 9 & 7.69 & 19 & 16.24 & 75 & 64.10 \\
\hline $\begin{array}{l}\text { I wanted to teach agriculture after my } \\
\text { student teaching experience* }\end{array}$ & 7 & 6.03 & 3 & 2.59 & 12 & 10.34 & 3 & 2.59 & 15 & 12.93 & 76 & 65.52 \\
\hline
\end{tabular}

*Reverse coded for data analysis 


\section{University Supervisor Visits}

Participants indicated the number of visits they received from their university supervisor during student teaching. Of the participants who responded to the question, 23 individuals (20.00\%) were visited 1-2 times by their university supervisor. Eighty-five participants (73.91\%) received 3-4 university supervisor visits; six people (5.22\%) were visited 5-6 times by their university supervisor; and one person (.87\%) received 7 or more university supervisor visits (see Table 11). The median category of university supervisor visits was 3-4 times.

Table 11

Number of University Supervisor Visits to Student Teachers

\begin{tabular}{lcc}
\hline Number of Visits & $N$ & $\%$ \\
\hline $1-2$ times & 23 & 20.00 \\
$3-4$ times & 85 & 73.91 \\
$5-6$ times & 6 & 5.22 \\
7 or more times & 1 & .87 \\
\hline
\end{tabular}

Number of SAE Visits Conducted by the Student Teacher during Student Teaching

The number of SAE visits conducted by individuals during student teaching was indicated by respondents. Of the individuals who responded, 80 individuals $(70.18 \%)$ completed 0-5 SAE visits. Sixteen people (14.04\%) completed 6-10 SAE visits. Respondents who had done 11-15 SAE visits included seven individuals (6.14\%). Three people $(2.63 \%)$ completed $16-20$ SAE visits. Four individuals (3.51\%) participated in 21-25 SAE visits and four individuals (3.51\%) completed more than 25 SAE visits (see Table 12). 
Table 12

Number of SAE Visits Conducted during Student Teaching

\begin{tabular}{lcc}
\hline Number of SAE visits & $N$ & $\%$ \\
\hline $0-5$ & 80 & 70.18 \\
$6-10$ & 16 & 14.04 \\
$11-15$ & 7 & 6.14 \\
$16-20$ & 3 & 2.63 \\
$21-25$ & 4 & 3.51 \\
more than 25 & 4 & 3.51 \\
\hline
\end{tabular}

Membership in the National FFA Organization

Respondents indicated if they had been a member of the National FFA

Organization. Twenty-six individuals $(22.22 \%)$ had not been a member of the National FFA Organization. Ninety-one people $(77.78 \%)$ had been a member of the National FFA Organization (see Table 13).

Table 13

Membership in the National FFA Organization of Individuals who Completed a Student Teaching Experience

\begin{tabular}{llc}
\hline Membership & $N$ & $\%$ \\
\hline No & 26 & 22.22 \\
Yes & 91 & 77.78 \\
\hline
\end{tabular}

Level of National FFA Membership

Individuals who had been a member of the National FFA Organization also indicated their level of membership. Ten individuals (10.99\%) were members of the FFA in middle school. Eighty-five respondents (92.39\%) were FFA members in high school. 
Forty-four individuals (47.83\%) had maintained FFA membership beyond high school.

Fifty-nine individuals (63.44\%) had been an FFA member at the collegiate level. Thirty participants (32.97\%) had been or were currently alumni FFA members (see Table 14).

Table 14

Levels of National FFA Membership

\begin{tabular}{lcc}
\hline FFA Membership & $N$ & $\%$ \\
\hline Middle School & 10 & 10.99 \\
High School & 85 & 92.39 \\
Maintained active membership beyond High School & 44 & 47.83 \\
Collegiate & 59 & 63.44 \\
Alumni & 30 & 32.97 \\
\hline
\end{tabular}

Number of Years of Active FFA Membership

Those individuals who had membership in the National FFA Organization were asked to indicate their length of active membership. Thirteen respondents $(14.29 \%)$ had 1-2 years of active FFA membership. Twenty-four individuals (26.37\%) completed 3-4 years of active FFA membership, 30 respondents (32.97\%) completed 5-6 years of active FFA membership, 22 people (24.18\%) had 7-8 years of active FFA membership, and two people $(2.20 \%)$ participated in 9-10 years of active FFA membership (see Table 15). The median category of active FFA membership was 5-6 years. 
Table 15

Years of Active FFA Membership of Individuals who had Completed a Student Teaching Experience

\begin{tabular}{ccc}
\hline Number of Years of Membership & $N$ & $\%$ \\
\hline $1-2$ & 13 & 14.29 \\
$3-4$ & 24 & 26.37 \\
$5-6$ & 30 & 32.97 \\
$7-8$ & 22 & 24.18 \\
$9-10$ & 2 & 2.20 \\
\hline
\end{tabular}

Highest Degree in the National FFA Organization Earned by Individuals who had Completed a Student Teaching Experience

Individuals who had been an FFA member also designated the highest FFA degree they earned in the organization. Of the individuals who had received an FFA degree, eight participants (9.64\%) had earned their Greenhand FFA degree;18 people $(21.69 \%)$ had earned a Chapter FFA degree; 25 respondents $(30.12 \%)$ had earned their State FFA degree; and 32 individuals (38.55\%) had earned an American FFA degree (see Table 16). The median FFA degree level was the State FFA degree.

Table 16

Highest FFA Degree Earned by Individuals who had Completed a Student Teaching Experience

\begin{tabular}{lrc}
\hline FFA Degree & $N$ & $\%$ \\
\hline Greenhand & 8 & 9.64 \\
Chapter & 18 & 21.69 \\
State & 25 & 30.12 \\
American & 32 & 38.55 \\
\hline
\end{tabular}


Types of Supervised Agricultural Experience Programs (SAE) Conducted by Individuals who had Completed a Student Teaching Experience

Individuals who had been in the FFA organization indicated the type(s) of Supervised Agricultural Experience Programs (SAE) they completed. Fifty-four people (58.70\%) had completed an entrepreneurship/ ownership SAE. Forty individuals (43.96\%) had completed a placement type SAE, 18 people (19.57\%) were involved in an exploratory SAE, and four participants (4.40\%) had completed a research/ experimentation SAE (see Table 17).

Table 17

Types of Supervised Agricultural Experience Programs (SAE) Conducted by Individuals who Completed a Student Teaching Experience

\begin{tabular}{lcc}
\hline Type & $N$ & $\%$ \\
\hline Entrepreneurship/ ownership & 54 & 58.70 \\
Placement & 40 & 43.96 \\
Exploratory & 18 & 19.57 \\
Research/ experimentation & 4 & 4.40 \\
\hline
\end{tabular}

\section{Chapter FFA Offices}

Individuals who had been an FFA member indicated if they had served as a chapter officer. Fifteen individuals (16.30\%) had not served as a chapter FFA officer. Of those who had been a chapter officer, 34 individuals (36.96\%) had served as chapter president; 29 people (31.52\%) had been a chapter vice-president; 14 respondents (15.38\%) had served as chapter secretary; 20 individuals (21.98\%) were chapter treasurer; 21 participants (23.08\%) had served as chapter reporter; and 11 individuals 
(12.09\%) had been a chapter sentinel (see Table 18). The most frequent chapter FFA office held was president.

Table 18

Chapter FFA Offices Held by Individuals who had Completed a Student Teaching Experience

\begin{tabular}{lcc}
\hline Chapter Office & $N$ & $\%$ \\
\hline President & 34 & 36.96 \\
Vice president & 29 & 31.52 \\
Secretary & 14 & 15.38 \\
Treasurer & 20 & 21.98 \\
Reporter & 21 & 23.08 \\
Sentinel & 11 & 12.09 \\
Parliamentarian & 4 & 4.40 \\
Historian & 4 & 4.40 \\
Chaplain & 5 & 5.49 \\
Junior Advisor & 7 & 7.69 \\
Ambassador & 1 & 1.10 \\
Board of Directors & 1 & 1.10 \\
Chairperson of several committees & 1 & 1.10 \\
Junior secretary & 1 & 1.10 \\
Assistant secretary & 1 & 1.09 \\
Junior Vice President & 1 & 1.10 \\
Freshman Vice President & 1 & 1.10 \\
None & 15 & 16.30 \\
\hline
\end{tabular}

National and State FFA Offices Held by Individuals who Completed a Student Teaching Experience

If respondents had been a member of the National FFA Organization, they were asked to specify if they had served as a state FFA officer. Sixty-eight individuals 
(73.91\%) had not held a state FFA office $($ Mode $=0$, none). Three individuals $(3.30 \%)$ had served as state FFA president. Seven people (7.69\%) served as a state FFA vice president; three individuals (3.30\%) had served as state FFA secretary; one person $(1.10 \%)$ had been state FFA treasurer; and one person $(1.10 \%)$ had served as a state FFA reporter (see Table 19). None of the individuals who responded had served as a national FFA officer.

Table 19

State FFA Offices Held by Individuals who Completed a Student Teaching Experience

\begin{tabular}{lcc}
\hline Office & $N$ & $\%$ \\
\hline President & 3 & 3.30 \\
Vice President & 7 & 7.69 \\
Secretary & 3 & 3.30 \\
Treasurer & 1 & 1.10 \\
Reporter & 1 & 1.10 \\
None & 68 & 73.91 \\
\hline
\end{tabular}

\section{Participation in Leadership Conferences}

Respondents who had been FFA members were asked to indicated their participation in leadership conferences. Fifty-seven individuals (62.64\%) had participated in a state leadership conference, 51 respondents $(56.04 \%)$ had been to a regional leadership conference, 46 individuals $(50.55 \%)$ had been involved in a chapter leadership conference, 22 participants (24.18\%) had attended a Made for Excellence (MFE) conference, and 19 respondents (20.88\%) had attended the Washington Leadership Conference (see Table 20). State leadership conferences included the most participation (Mode $=$ state leadership conference). 
Table 20

Participation in Leadership Conferences during Years of FFA Membership by Individuals who Completed a Student Teaching Experience

\begin{tabular}{lcc}
\hline Leadership Conference & $N$ & $\%$ \\
\hline State Leadership conference & 57 & 62.64 \\
Regional Leadership conference & 51 & 56.04 \\
Chapter Leadership conference & 46 & 50.55 \\
Made for Excellence (MFE) & 22 & 24.18 \\
Washington Leadership Conference (WLC) & 19 & 20.88 \\
Building Leaders and Strong Teams of Officers & & \\
(BlastOFF) & 13 & 14.29 \\
National Leadership Conference for State Officers & & \\
(NLCSO) & 12 & 13.19 \\
State Presidents Conference (SPC) & 10 & 10.99 \\
ILSSO & 3 & 3.30 \\
Carolina State Officer Leadership Training & 2 & 2.20 \\
Experiencing Discovery, Growth and Excellence & & 1.10 \\
(EDGE) & 1 & 1.10 \\
Advanced Leadership Development (ALD) & 1 & 1.10 \\
Leadership Camp & 1.10 \\
PALS Training & 1 & 1.10 \\
Southeast Conclave & 1 & 1.10 \\
National Convention Workshops & 1 & 1.10 \\
AQHYA National Leadership Conference & 1 & \\
NCTSO & 1 & \\
ACES & 1 & \\
Mega Conference & 10 \\
PCC and NICE & 10 \\
\hline & 10 \\
\hline
\end{tabular}




\section{Participation in FFA Career Development Events (CDE) during Years of FFA}

Membership by Individuals who Completed a Student Teaching Experience

Individuals who had been members of the National FFA Organization were asked to designate their highest level of Career Development Event (CDE) participation. The chapter level was listed 132 times by respondents as the highest level of participation for various $\mathrm{CDE}$ contests. The most frequently mentioned chapter level $\mathrm{CDE}$ was the creed speaking $\operatorname{CDE}(N=19,20.88 \%)$ (see Table 21). Respondents listed 97 regional Career Development Events as the highest level of participation for various CDE contests. The $\mathrm{CDE}$ individuals most frequently participated in at the regional level was the parliamentary procedure $\operatorname{CDE}(N=27,29.67 \%)$ (see Table 21$)$. Respondents listed 186 state Career Development Events as the highest level of participation for various CDE contests. The most common CDE participation at the state level was in the land judging competition $(N=18,19.78 \%)$ (see Table 21). Participants listed 47 national Career Development Events as the highest level of participation for various CDE contests. The Floriculture $\operatorname{CDE}(N=5,5.49 \%)$ and Parliamentary Procedure CDE $(N=5,5.49 \%)$ had the highest rate of participation on the national level (see Table 21). 
Table 21

Participation in FFA Career Development Events (CDE) during Years of FFA Membership by Individuals who Completed a Student

\section{Teaching Experience}

\begin{tabular}{|c|c|c|c|c|c|c|c|c|}
\hline \multirow[t]{3}{*}{$\mathrm{CDE}$} & \multicolumn{8}{|c|}{ Level of CDE Participation } \\
\hline & \multicolumn{2}{|c|}{ Chapter } & \multicolumn{2}{|c|}{ Regional } & \multicolumn{2}{|c|}{ State } & \multicolumn{2}{|c|}{ National } \\
\hline & $N$ & $\%$ & $N$ & $\%$ & $N$ & $\%$ & $N$ & $\%$ \\
\hline Ag communications & 3 & 3.30 & 2 & 2.20 & 2 & 2.20 & 0 & 0.00 \\
\hline $\mathrm{Ag}$ issues & 3 & 3.30 & 1 & 1.10 & 3 & 3.30 & 3 & 3.30 \\
\hline Ag mechanics & 6 & 6.59 & 1 & 1.10 & 9 & 9.89 & 1 & 1.10 \\
\hline Ag sales & 3 & 3.30 & 0 & 0.00 & 5 & 5.49 & 4 & 4.40 \\
\hline Agronomy & 7 & 7.69 & 2 & 2.20 & 0 & 0.00 & 2 & 2.20 \\
\hline Creed speaking & 19 & 20.88 & 9 & 9.89 & 11 & 12.09 & 1 & 1.10 \\
\hline Dairy cattle & 7 & 7.69 & 4 & 4.40 & 12 & 13.19 & 2 & 2.20 \\
\hline Dairy handler & 1 & 1.10 & 0 & 0.00 & 2 & 2.20 & 0 & 0.00 \\
\hline Dairy foods & 4 & 4.40 & 0 & 0.00 & 5 & 5.49 & 2 & 2.20 \\
\hline Environmental and natural resources & 4 & 4.40 & 0 & 0.00 & 4 & 4.40 & 2 & 2.20 \\
\hline Extemporaneous speaking & 9 & 9.89 & 8 & 8.79 & 6 & 6.59 & 1 & 1.10 \\
\hline Farm business management & 4 & 4.40 & 1 & 1.10 & 7 & 7.69 & 3 & 3.30 \\
\hline Floriculture & 2 & 2.20 & 3 & 3.30 & 11 & 12.09 & 5 & 5.49 \\
\hline Food science and technology & 1 & 1.10 & 0 & 0.00 & 0 & 0.00 & 0 & 0.00 \\
\hline
\end{tabular}


Table 21 (Continued)

Participation in FFA Career Development Events (CDE) during Years of FFA Membership by Individuals who Completed a Student

\section{Teaching Experience}

\begin{tabular}{|c|c|c|c|c|c|c|c|c|}
\hline \multirow[t]{3}{*}{$\mathrm{CDE}$} & \multicolumn{8}{|c|}{ Level of CDE Participation } \\
\hline & \multicolumn{2}{|c|}{ Chapter } & \multicolumn{2}{|c|}{ Regional } & \multicolumn{2}{|c|}{ State } & \multicolumn{2}{|c|}{ National } \\
\hline & $N$ & $\%$ & $N$ & $\%$ & $N$ & $\%$ & $N$ & $\%$ \\
\hline Forestry & 10 & 10.99 & 12 & 13.19 & 9 & 9.89 & 2 & 2.20 \\
\hline Horse evaluation & 4 & 4.40 & 1 & 1.10 & 12 & 13.19 & 0 & 0.00 \\
\hline Job interview & 3 & 3.30 & 1 & 1.10 & 1 & 1.10 & 0 & 0.00 \\
\hline Land judging & 6 & 6.59 & 2 & 2.20 & 18 & 19.78 & 4 & 4.40 \\
\hline Livestock evaluation & 7 & 7.69 & 7 & 7.69 & 17 & 18.68 & 2 & 2.20 \\
\hline Marketing plan & 0 & 0.00 & 0 & 0.00 & 2 & 2.20 & 0 & 0.00 \\
\hline Meats evaluation & 3 & 3.30 & 0 & 0.00 & 3 & 3.30 & 1 & 1.10 \\
\hline Nursery landscape & 4 & 4.40 & 7 & 7.69 & 7 & 7.69 & 4 & 4.40 \\
\hline Parliamentary procedure & 7 & 7.69 & 27 & 29.67 & 14 & 15.38 & 5 & 5.49 \\
\hline Poultry evaluation & 4 & 4.40 & 2 & 2.20 & 12 & 13.19 & 1 & 1.10 \\
\hline Public speaking & 11 & 12.09 & 7 & 7.69 & 13 & 14.29 & 1 & 1.10 \\
\hline Tractor driving & 0 & 0.00 & 0 & 0.00 & 1 & 1.10 & 0 & 0.00 \\
\hline Grassland evaluation & 0 & 0.00 & 0 & 0.00 & 0 & 0.00 & 1 & 1.10 \\
\hline Total & 132 & & 97 & & 186 & & 47 & \\
\hline
\end{tabular}


Participation in FFA Activities during Years of FFA Membership by Individuals who Completed a Student Teaching Experience

Respondents who were past FFA members specified the activities in which they participated during their years of FFA membership. Eighty-five individuals (92.39\%) had participated in chapter fundraisers. Seventy-six respondents $(82.61 \%)$ had taken part in community service projects. Fifty-seven individuals (61.96\%) had participated in fair exhibits. Twenty-four individuals (26.09\%) had been active in Food for America; and 21 people (23.08\%) had participated in Partners in Active Learning Success (PALS) (see Table 22).

Table 22

Participation in FFA Activities during Years of FFA Membership by Individuals who Completed a Student Teaching Experience

\begin{tabular}{lcc}
\hline Chapter Activities & $N$ & $\%$ \\
\hline Fundraisers & 85 & 92.39 \\
Community service projects & 76 & 82.61 \\
Fair exhibits & 57 & 61.96 \\
Food for America & 24 & 26.09 \\
PALS & 21 & 23.08 \\
Agriscience & 13 & 14.29 \\
Risk Management Essay contest & 2 & 2.20 \\
Meetings & 2 & 2.20 \\
Informative displays & 2 & 2.20 \\
State chorus & 1 & 1.10 \\
Chapter field trips & 1 & 1.10 \\
FFA camp & 1 & 1.10 \\
State Agriculture in the Classroom & & \\
conference & 1 & 1.10 \\
National Agriculture in the Classroom & & \\
conference & 1 & 1.10 \\
\hline
\end{tabular}


Highest Level of FFA Proficiency Awards Earned during Years of FFA Membership by Individuals who Completed a Student Teaching Experience

Participants with a background in the FFA organization indicated their highest level of proficiency award achievement. Thirty-five people (37.63\%) indicated their highest level of proficiency award was at the chapter level and 16 individuals (17.20\%) indicated their highest level of proficiency award was at the state level. Forty-two individuals $(45.16 \%)$ had not received a proficiency award $($ Mode $=$ none $)($ see Table 23$)$.

Table 23

Highest Level of FFA Proficiency Awards Earned during Years of FFA Membership by Individuals who Completed a Student Teaching Experience

\begin{tabular}{lcc}
\hline Level of Proficiency Award & $N$ & $\%$ \\
\hline Chapter & 35 & 37.63 \\
State & 16 & 17.20 \\
None & 42 & 45.16 \\
\hline
\end{tabular}

4-H Membership of Individuals who Completed a Student Teaching Experience

Respondents were asked to indicate their membership in the 4-H organization. Seventy people (59.83\%) had not been a member of 4-H. Of the respondents, 47 people (40.17\%) had been a member of 4-H (see Table 24).

Table 24

4-H Membership of Individuals who Completed a Student Teaching Experience

\begin{tabular}{ccc}
\hline Membership & $N$ & $\%$ \\
\hline No & 70 & 59.83 \\
Yes & 47 & 40.17 \\
\hline
\end{tabular}


Years of 4-H Participation of Individuals who Completed a Student Teaching Experience Individuals who indicated a 4-H membership were asked to specify the number of years of participation in the organization. The median category for years of participation was 9-10 years. Three people (6.38\%) participated in 4-H for 1-2 years, eight individuals $(17.02 \%)$ were participants in $4-\mathrm{H}$ for $3-4$ years, four people $(8.51 \%)$ were participants in 4-H for 5-6 years, six people (12.77\%) participated in 4-H for 7-8 years, 12 people $(25.53 \%)$ were participants for $9-10$ years in $4-\mathrm{H}$, seven people $(14.89 \%)$ had participated in 4-H for 11-12 year, and seven respondents (14.89\%) had been participants in 4-H for 13 or more years (see Table 25).

Table 25

Years of 4-H Participation of Individuals who Completed a Student Teaching Experience

\begin{tabular}{lcc}
\hline Number of Years & $N$ & $\%$ \\
\hline $1-2$ & 3 & 6.38 \\
$3-4$ & 8 & 17.02 \\
$5-6$ & 4 & 8.51 \\
$7-8$ & 6 & 12.77 \\
$9-10$ & 12 & 25.53 \\
$11-12$ & 7 & 14.89 \\
13 or more & 7 & 14.89 \\
\hline
\end{tabular}

Participation in 4-H Projects by Individuals who Completed a Student Teaching Experience

Participants who had been in the 4-H organization indicated their participation in 4-H projects. Four individuals $(8.51 \%)$ did not have a project while in 4-H. Forty-three respondents $(91.49 \%)$ had completed a project in 4-H (Mode $=1$, yes) (see Table 26). 
Table 26

Participation in 4-H Projects by Individuals who Completed a Student Teaching Experience

\begin{tabular}{lrc}
\hline 4-H Project & $N$ & $\%$ \\
\hline No & 4 & 8.51 \\
Yes & 43 & 91.49 \\
\hline
\end{tabular}

4-H Project Areas Completed by Individuals who Completed a Student Teaching Experience

The respondents who had a 4-H project as a 4-H member were asked to specify all the project areas they had completed. Eight people (19.05\%) had completed a project in the area of citizenship and civic education. Four people $(9.52 \%)$ completed a communication and expressive arts project. The consumer and family science project category included 12 individuals (28.57\%). Environmental education and earth sciences projects were completed by four survey participants $(9.52 \%)$. Twelve people $(28.57 \%)$ had completed projects in the area of personal development and leadership. Thirty-nine respondents $(90.70 \%)$ had a project involving plants and animals and seven people $(16.67 \%)$ had completed a project in the area of science and technology (see Table 27). The most common project area was plants and animals (Mode $=$ plants and animals). 
Table 27

Participation in 4-H Projects by Individuals who Completed a Student Teaching Experience

\begin{tabular}{lcc}
\hline Project Areas & $N$ & $\%$ \\
\hline Plants and animals & 39 & 90.70 \\
Consumer and family science & 12 & 28.57 \\
Personal development and leadership & 12 & 28.57 \\
Citizenship and civic education & 8 & 19.05 \\
Science and technology & 7 & 16.67 \\
Communication and expressive arts & 4 & 9.52 \\
Environmental education and earth sciences & 4 & 9.52 \\
Healthy lifestyles education & 3 & 7.14 \\
\hline
\end{tabular}

4-H Club Offices Held by Individuals who completed a Student Teaching Experience Individuals who had been in 4-H were asked to indicate their service as a club officer. Twenty-eight individuals (59.57\%) had served as club president, 20 people (43.48\%) had served as club vice president, 22 respondents $(46.81 \%)$ had been club secretary, and 17 people (36.96\%) had been club reporter. Nine individuals $(19.57 \%)$ had not served as a 4-H club officer (see Table 28). 
Table 28

4-H Club Offices Held by Individuals who completed a Student Teaching Experience

\begin{tabular}{lcc}
\hline Office & $N$ & $\%$ \\
\hline President & 28 & 59.57 \\
Vice president & 20 & 43.48 \\
Secretary & 22 & 46.81 \\
Treasurer & 17 & 36.96 \\
Regional/district reporter & 2 & 4.35 \\
Reporter & 4 & 8.70 \\
Song leader & 1 & 2.17 \\
Song game leader & 1 & 2.17 \\
County livestock president & 1 & 2.17 \\
Advisory board member & 1 & 2.17 \\
None & 9 & 19.57 \\
\hline
\end{tabular}

Participation in 4-H Activities by Individuals who Completed a Student Teaching

Experience

Respondents who were past 4-H members specified the activities in which they participated during their years of membership. Thirty-two people $(68.09 \%)$ had completed 4-H fair exhibits, 23 people (48.94\%) had participated in 4-H project workshops, 23 people (48.94\%) had competed in state 4-H judging contests, 21 individuals (45.65\%) had been a camp counselor, and 20 respondents (43.48\%) had been to county 4-H camp (see Table 29). 
Table 29

Participation in 4-H Activities by Individuals who Completed a Student Teaching Experience

\begin{tabular}{|c|c|c|}
\hline Activity & $N$ & $\%$ \\
\hline 4-H fair exhibits & 32 & 68.09 \\
\hline 4-H project workshops & 23 & 48.94 \\
\hline 4-H state judging contests & 23 & 48.94 \\
\hline 4-H camp counselor & 21 & 45.65 \\
\hline County 4-H camp & 20 & 43.48 \\
\hline Junior 4-H leader & 12 & 26.09 \\
\hline 4-H club leader & 12 & 25.53 \\
\hline 4-H officer's training school & 11 & 23.91 \\
\hline National 4-H congress & 8 & 17.39 \\
\hline 4-H team leader weekend & 7 & 15.22 \\
\hline 4-H advisory council & 7 & 15.22 \\
\hline 4-H national judging contests & 7 & 14.89 \\
\hline Summer 4-H camp & 2 & 4.26 \\
\hline State 4-H camp & 2 & 4.35 \\
\hline Alpha I 4-H camp & 2 & 4.35 \\
\hline Regional 4-H camp & 2 & 4.35 \\
\hline 4-H OMC & 2 & 4.35 \\
\hline 4-H All-Star & 2 & 4.35 \\
\hline 4-H regional resource camp & 1 & 2.17 \\
\hline 4-H horse camp & 1 & 2.17 \\
\hline Alpha II 4-H camp & 1 & 2.17 \\
\hline Electric congress $4-\mathrm{H}$ & 1 & 2.17 \\
\hline $\begin{array}{l}\text { Workshop held for younger members on } \\
\text { showing goats }\end{array}$ & 1 & 2.17 \\
\hline State events congress and retreats & 1 & 2.17 \\
\hline Teens reaching youth TRU & 1 & 2.17 \\
\hline Regional Fashion Review & 1 & 2.17 \\
\hline
\end{tabular}


Table 29 (Continued)

Participation in 4-H Activities by Individuals who Completed a Student Teaching Experience

\begin{tabular}{lll}
\hline Activity & $N$ & $\%$ \\
\hline County, District \& State Horse Shows & 1 & 2.17 \\
State 4-H congress & 1 & 2.17 \\
Citizenship Washington Focus & 1 & 2.17 \\
Teen Ambassadors & 1 & 2.17 \\
YAC & 1 & 2.17 \\
Summer Activities & 1 & 2.17 \\
County livestock show & 1 & 2.17 \\
Livestock judging & 1 & 2.17 \\
\hline
\end{tabular}

Participants' Comments

Participants had the opportunity to write additional comments at the end of the questionnaire. The researcher categorized these comments based on similar themes.

Fifteen of the respondents who made comments (12.80\%) indicated they had a bad student teaching experience. The respondents who had a bad student teaching experience cited 11 different reasons. Three individuals (2.60\%) indicated the reason was because of their cooperating teacher. One respondent stated, "I felt expectations were held too high that I could not accomplish without more help from the cooperating teacher." Two participants (1.70\%) had classroom management issues, and two people $(1.70 \%)$ had a bad student teaching experience because of a lack of university supervisor support. Two respondents (1.70\%) indicated their bad student teaching experience caused delayed entrance into teaching agriculture. One respondent commented, "I was overall disappointed $w / m y$ student teaching placement and decided not to teach $b / c$ of it." 
Other reasons respondents listed included: community politics, problems with students in an urban setting, difficulty planning lessons with no background experience, student teaching was overwhelming and exhausting, and the student teaching site assignment was not their first choice.

Three individuals (2.60\%) who provided comments had a positive student teaching experience. Reasons given included: good cooperating teacher, growing as a person, and student teaching helped with presentations skills for another job

Eight individuals (6.80\%) had left teaching agriculture. Their reasons included: educational laws and regulations, certification renewal regulations, teacher to student ratio, student attitudes, funding issues, program cuts, lack of confidence in abilities, and lack of administrative support. Individual comments included, "Constantly seem to be worrying about even having agriculture in the future. Schools are always looking to cut."

Ten respondents $(8.50 \%)$ listed reasons they wanted to teach agriculture. Those reasons included: good experience with students, student teaching experience, cooperating teacher, high school agriculture teacher, university supervisor, student success, upper college classes, college faculty, make school fun for students, and to help agriculture. One participant wrote "I was very fortunate to have the agriculture teacher I had as well as the wonderful student teaching experience and university support. Without those 3 things I am not sure I would have the confidence and desire to overcome the difficulties of being a first year teacher."

Nine respondents (7.70\%) offered comments and suggestions regarding the student teaching experience. Two people (1.70\%) suggested a better student teaching site selection process is needed. One respondent wrote: 
I think there should be more planning involved in choosing cooperating sites. Prospective student teachers should have to visit prospective cooperating centers the year prior to student teaching. Student teachers should also be informed of each prospective cooperating teacher's course load so they can be better prepared! Two respondents $(1.7 \%)$ stated their assigned cooperating teacher was not helpful. One of those respondents wrote "The other person at the high school was much more supportive of me as a teacher." Other comments included: cooperating teacher lacked guidance and involvement, limited knowledge about agriculture programs in the state, and student teaching is important.

Research Questions One and Two

Research questions one and two of the study sought to determine the differences that existed in student teaching site selection processes, cooperating teacher characteristics, and university supervisor characteristics associated with individuals who were not satisfied with the student teaching experience compared to individuals who were satisfied.

To categorize respondents into "satisfied" with student teaching and "dissatisfied" with student teaching, the researchers calculated a mean composite score of questions associated with the overall student teaching experience (survey questions 44 , 45, and 46). Those questions included "I was satisfied with my student teaching experience;" "My student teaching experience reinforced my decision to become a teacher;" and "My student teaching experience discouraged me from becoming a teacher." Those averages were then coded into "satisfied" and "dissatisfied" categories. 
The "dissatisfied" category consisted of the averaged values ranging from 0-3.5. The "satisfied" category included the averaged values ranging from 3.51-6.0.

The means of the Likert type statements dealing with the student teaching site selection were calculated. Individuals who were satisfied with student teaching $(M=$ $4.50, S D=1.42$ ) rated the statement "the selection of my student teaching site was solely my decision" higher than individuals who were dissatisfied with their student teaching experience $(M=4.20, S D=1.70)$. The group mean was 4.45 with a standard deviation of 1.47 (see Table 30).

The statement "I had input into the selection of my student teaching site" was rated higher by respondents who were satisfied with student teaching $(M=5.05, S D=$ 1.37) compared to respondents who were dissatisfied $(M=4.45, S D=1.70)$. The group mean was 4.95 with a standard deviation of 1.44 (see Table 30).

Individuals who were satisfied with student teaching felt the university had less of an influence on their site selection $(M=3.95, S D=1.47)$ than individuals who were dissatisfied with student teaching $(M=4.00, S D=1.45)$. The group mean was 3.96 with a standard deviation of 1.46 (see Table 30).

Individuals who were satisfied with student teaching rated the statement "other people in the agricultural profession influenced my student teaching site selection" higher $(M=3.60, S D=1.57)$ compared to individuals who were dissatisfied with student teaching $(M=2.95, S D=1.50)$. The group mean was 3.49 with a standard deviation of 1.57 (see Table 30).

Respondents who were satisfied with student teaching rated the statement "my student teaching placement site was my first choice with a mean of 5.00 and a standard 
deviation of 4.65. In contrast, dissatisfied respondents rated the same statement with a mean of 4.65 and a standard deviation of 1.98. The mean of the combined groups was 4.94 with a standard deviation of 1.72 (see Table 30$)$.

Individuals who were satisfied with student teaching rated the statement "I requested a student teaching site to match my strengths" with a mean of 4.14 and a standard deviation of 1.54. People who were dissatisfied with student teaching had a mean of 3.30 with a standard deviation of 1.72 for the same statement. The group mean was 3.99 with a standard deviation of 1.60 (see Table 30).

Respondents who were satisfied with student teaching had a mean of 3.88 and a standard deviation of 1.52 for the statement "I requested a student teaching site to improve my weaknesses." Individuals who were dissatisfied with student teaching rated the statement with a mean of $3.55(S D=1.79)$. The group had a mean of 4.02 with a standard deviation of 1.52 (see Table 30$)$.

Satisfied individuals had a mean of 4.22 and a standard deviation of 1.63 for the statement "I requested a student teaching site based on the agriculture teacher there." Those who were dissatisfied with their student teaching experience rated the statement with a mean of 3.05 and a standard deviation of 1.79 . The group mean was 4.02 with a standard deviation of 1.71 (see Table 30$)$.

Individuals who were satisfied with student teaching rated the statement "I requested a student teaching site based on the facilities" with a mean of 3.29 and a standard deviation of 1.58. The dissatisfied respondents had a mean of 2.90 with a standard deviation of 1.80. The group had a mean of 3.23 and a standard deviation equaling 1.62 (see Table 30). 
Table 30

Student Teaching Site Selection Variables for Satisfied and Dissatisfied Individuals

\begin{tabular}{|c|c|c|c|c|c|c|}
\hline \multirow[t]{3}{*}{ Site Selection Variables } & \multicolumn{4}{|c|}{ Satisfaction } & \multicolumn{2}{|c|}{ Group Total } \\
\hline & \multicolumn{2}{|c|}{ Dissatisfied } & \multicolumn{2}{|c|}{ Satisfied } & \multirow[b]{2}{*}{$M$} & \multirow[b]{2}{*}{$S D$} \\
\hline & $M$ & $S D$ & $M$ & $S D$ & & \\
\hline $\begin{array}{l}\text { The selection of my student teaching } \\
\text { site was solely my decision }\end{array}$ & 4.20 & 1.70 & 4.50 & 1.42 & 4.45 & 1.47 \\
\hline $\begin{array}{l}\text { I had input into the selection of my } \\
\text { student teaching site* }\end{array}$ & 4.45 & 1.70 & 5.05 & 1.37 & 4.95 & 1.44 \\
\hline $\begin{array}{l}\text { University faculty influenced my } \\
\text { student teaching site selection }\end{array}$ & 4.00 & 1.45 & 3.95 & 1.47 & 3.96 & 1.46 \\
\hline $\begin{array}{l}\text { Other people in the agricultural } \\
\text { education profession influenced my } \\
\text { student teaching site selection }\end{array}$ & 2.95 & 1.50 & 3.60 & 1.57 & 3.49 & 1.57 \\
\hline $\begin{array}{l}\text { My student teaching placement site } \\
\text { was my first choice }\end{array}$ & 4.65 & 1.98 & 5.00 & 1.67 & 4.94 & 1.72 \\
\hline $\begin{array}{l}\text { I requested a student teaching site to } \\
\text { match my strengths }\end{array}$ & 3.30 & 1.72 & 4.14 & 1.54 & 3.99 & 1.60 \\
\hline $\begin{array}{l}\text { I requested a student teaching site to } \\
\text { improve my weaknesses }\end{array}$ & 3.55 & 1.50 & 3.88 & 1.52 & 3.83 & 1.52 \\
\hline $\begin{array}{l}\text { I requested a student teaching site } \\
\text { based on the agriculture teacher there }\end{array}$ & 3.05 & 1.79 & 4.22 & 1.63 & 4.02 & 1.71 \\
\hline $\begin{array}{l}\text { I requested a student teaching site } \\
\text { based on the facilities }\end{array}$ & 2.90 & 1.80 & 3.29 & 1.58 & 3.23 & 1.62 \\
\hline $\begin{array}{l}\text { I requested a student teaching site } \\
\text { based on the location of the school }\end{array}$ & 4.90 & 1.59 & 4.86 & 1.47 & 4.87 & 1.48 \\
\hline $\begin{array}{l}\text { I was satisfied with my student } \\
\text { teaching placement site* }\end{array}$ & 3.00 & 2.08 & 5.55 & 1.10 & 5.11 & 1.63 \\
\hline
\end{tabular}

*Reverse coded for data analysis

Satisfied respondents rated the statement "I requested a student teaching site based on the location of the school" with a mean value of 4.86 and a standard deviation of 1.47. Dissatisfied individuals gave the same statement a higher value with a mean of 
4.90 and a standard deviation of 1.59. The group had a mean of 4.87 and a standard deviation of 1.48 (see Table 30).

Individuals who were satisfied with student teaching had a mean of 5.55 ( $S D=$ 1.10) for the statement "I was satisfied with my student teaching placement site.

Whereas, dissatisfied individuals ranked the statement with a mean of $3.00(S D=2.08)$. The group mean was 5.11 with a standard deviation of 1.63 (see Table 30).

A $t$-test statistical procedure was used to determine if differences existed in student teaching site selection variables, when comparing individuals who were satisfied and dissatisfied with their student teaching experience. Two site selection variables were significantly different at $\alpha \leq .05$. Respondents who were satisfied with student teaching $(M=4.14, S D=1.54)$ rated the statement "I requested a student teaching site to match my strengths" higher than dissatisfied individuals $(M=3.30, S D=1.72)(t=2.163, d f=$ 113) (see Table 31). The difference exhibited a small effect (Cohen, 1988). Respondents who were satisfied with student teaching $(M=5.55, S D=1.10)$ were more satisfied with their student teaching placement site than individuals who were dissatisfied with student teaching $(\mathrm{M}=3.00, S D=2.08)(t=5.339, d f=21.286)($ see Table 31$)$. The difference between the means exhibited a large effect (Cohen, 1988). 
Table 31

Comparison of Means of Student Teaching Site Selection Variables for Satisfied and Dissatisfied Individuals

Site Selection Variables

$\underline{\text { Student Teaching Satisfaction }}$

Satisfied Dissatisfied

$\begin{array}{llll}M & \text { M } & \mathrm{d}\end{array}$

I requested a student teaching site to

match my strengths

4.14

3.30

$2.163 * \quad 113$

I was satisfied with my student

teaching placement site

5.55

$* \alpha \leq .05$

The means of the Likert type statements addressing cooperating teacher characteristics were calculated for those satisfied and dissatisfied with their student teaching experience. Individuals satisfied with student teaching rated the statement "my cooperating teacher introduced my credentials to help establish my rapport with the students" with a mean equaling 5.01 and standard deviation of 1.12. Individuals dissatisfied had a mean of 3.70 and a standard deviation of 1.78 for the same statement. The mean of the two groups was $4.78(S D=1.34)$ (see Table 32$)$.

When responding to the statement "my cooperating teacher was readily available to answer my questions," satisfied individuals had a mean of 5.64 and a standard deviation of .84. Dissatisfied respondents had a mean of $3.75(S D=1.80)$. The group mean was 5.31 with a standard deviation of 1.27 (see Table 32).

Individuals who were satisfied with student teaching had a mean value of 5.77 $(S D=.51)$ for the statement "my cooperating teacher supported my decisions in front of students." Dissatisfied respondents valued the statement with mean of 3.70 and a 
standard deviation of 1.87 . The group mean was 5.41 with a standard deviation of 1.19 (see Table 32).

Respondents who were satisfied with student teaching had a mean of $5.72(S D=$ .51) for the statement "my cooperating teacher was willing to help me in any way possible." Those dissatisfied with student teaching valued the same statement with a mean equaling 3.60 and a standard deviation of 1.54 . The group mean was $5.35(S D=$ 1.23) (see Table 32).

The statement "my cooperating teacher provided me with adequate guidance" was rated by satisfied individuals with a mean of $4.26(S D=1.56)$. Dissatisfied individuals rated the statement with a mean of $2.30(S D=1.63)$. The group mean was $3.91(S D=$ 1.73) (see Table 32).

Satisfied individuals possessed a mean of $4.57(S D=1.46)$ for the statement "my cooperating teacher evaluated my performance each week. Those who were dissatisfied with student teaching gave the statement a mean of $3.25(S D=1.71)$. The group mean was $4.34(S D=1.58)($ see Table 32$)$.

The statement "my cooperating teacher encouraged me to go with him/her and students to FFA events and activities" received a mean of $5.65(S D=.79)$ from individuals who were satisfied with their student teaching experience. Individuals who were dissatisfied ranked the statement with a $4.60(S D=1.82)$. The group mean was 5.47 with a standard deviation of 1.11 (see Table 32).

Respondents who were satisfied with student teaching had a mean value of 5.28 $(S D=1.05)$ for the statement "my cooperating teacher provided feedback about my progress during student teaching." Dissatisfied individuals gave the statement a mean of 
3.50 with a standard deviation of 1.43 . The group mean was 4.97 with a standard deviation of 1.31 (see Table 32).

Those who were satisfied with student teaching valued the statement "my cooperating teacher had a positive attitude toward teaching" with a mean of $5.67(S D=$ .71). Respondents dissatisfied with student teaching rated the statement with a mean of $3.55(S D=1.79)$. The group mean was 5.41 with a standard deviation of 1.04 (see Table $32)$.

Satisfied individuals rated the statement "my cooperating teacher had a positive attitude toward students" with a mean of $5.65(S D=.68)$. Dissatisfied individuals rated the statement with a mean of $4.25(S D=1.59)$. The group had a mean of 5.41 and a standard deviation of 1.04 (see Table 32).

Individuals who were satisfied with student teaching rated the statement "my cooperating teacher had a positive attitude toward the agricultural education profession" with a mean of $5.72(S D=.61)$. The dissatisfied individuals had a mean of $4.20(S D=$ 4.20) for the same statement. The group mean was $5.46(S D=1.07)$ (see Table 32).

Respondents satisfied with student teaching rated the statement "my cooperating teacher created a good working atmosphere" with a mean of $5.60(S D=.93)$.

Respondents who were dissatisfied rated the statement with a mean of 3.20 and a standard deviation of 3.20 and a standard deviation of 1.82 . The group mean was 5.19 $(S D=1.45)($ see Table 32)

Individuals who were satisfied with student teaching rated the statement "I was permitted to miss school to travel with my cooperating teacher to professional meetings" with a mean of 5.48 and a standard deviation of 1.10. Respondents dissatisfied with 
student teaching rated the statement with a mean of 4.59 and a standard deviation of 1.66. The group mean was 5.34 with a standard deviation of 1.24 (see Table 32).

Satisfied individuals rated "my cooperating teacher gave me guidance regarding SAE visits" with a mean value of $4.61(S D=1.59)$. The individuals dissatisfied with student teaching gave the statement a mean of $3.53(S D=2.04)$. The group totaled a mean of 4.42 and a standard deviation of 1.72 (see Table 32).

Individuals satisfied with student teaching rated the statement "I had a positive relationship with my cooperating teacher" with a mean of 5.75 and a standard deviation of .71. Individuals not satisfied with student teaching rated the statement with a mean of 3.40 and a standard deviation valued at 1.82 (see Table 32).

Satisfied individuals gave the statement "my cooperating teacher helped me with discipline issues" a mean of 5.35 and a standard deviation of 1.03 . Those dissatisfied with student teaching rated the statement with a mean of 3.50 and a standard deviation of 1.82. The group valued the statement at a mean of 5.03 and a standard deviation of 1.38 (see Table 32).

Those who were satisfied with student teaching rated the statement "my cooperating teacher and university supervisor discussed my progress" with a mean of 5.54 and a standard deviation of .76. Those who were dissatisfied rated the same statement with a mean of 4.40 and a standard deviation of 1.27 (see Table 32). 
Table 32

Cooperating Teacher Characteristics for Satisfied and Dissatisfied Individuals

\begin{tabular}{lllllll}
\hline \multirow{2}{*}{ Cooperating Teacher Characteristics } & \multicolumn{3}{c}{ Satisfaction } & \multirow{2}{*}{ Group Total } \\
\cline { 2 - 5 } & \multicolumn{2}{c}{ Dissatisfied } & \multicolumn{2}{c}{ Satisfied } & & \\
\cline { 2 - 7 } & $M$ & $S D$ & $M$ & $S D$ & $M$ & $S D$ \\
\hline
\end{tabular}

My cooperating teacher introduced my credentials to help establish my rapport with the students

$\begin{array}{llllll}3.70 & 1.78 & 5.01 & 1.12 & 4.78 & 1.34\end{array}$

My cooperating teacher was readily available to answer my questions

$\begin{array}{llllll}3.75 & 1.80 & 5.64 & .84 & 5.31 & 1.27\end{array}$

My cooperating teacher supported my decisions in front of students

$\begin{array}{llllll}3.70 & 1.87 & 5.77 & .51 & 5.41 & 1.19\end{array}$

My cooperating teacher was willing to help me in any way possible

$\begin{array}{llllll}3.60 & 1.54 & 5.72 & .76 & 5.35 & 1.23\end{array}$

My cooperating teacher provided me with adequate guidance*

$\begin{array}{llllll}2.30 & 1.63 & 4.26 & 1.56 & 3.91 & 1.73\end{array}$

My cooperating teacher evaluated my performance each week

$\begin{array}{llllll}3.25 & 1.71 & 4.57 & 1.46 & 4.34 & 1.58\end{array}$

My cooperating teacher encouraged me to go with him/her and students to FFA events and activities

$\begin{array}{llllll}4.60 & 1.82 & 5.65 & .79 & 5.47 & 1.11\end{array}$

My cooperating teacher provided feedback about my progress during student teaching

$\begin{array}{llllll}3.50 & 1.43 & 5.28 & 1.05 & 4.97 & 1.31\end{array}$

My cooperating teacher had a positive attitude toward teaching

$\begin{array}{llllll}3.55 & 1.79 & 5.67 & .71 & 5.30 & 1.26\end{array}$

My cooperating teacher had a positive attitude toward students

$\begin{array}{llllll}4.25 & 1.59 & 5.65 & .68 & 5.41 & 1.04\end{array}$

My cooperating teacher had a positive attitude toward the agricultural education profession

$\begin{array}{llllll}4.20 & 1.77 & 5.72 & .61 & 5.46 & 1.07\end{array}$

My cooperating teacher created a good working atmosphere

$\begin{array}{llllll}3.20 & 1.82 & 5.60 & .93 & 5.19 & 1.45\end{array}$


Table 32 (Continued)

Cooperating Teacher Characteristics for Satisfied and Dissatisfied Individuals

\begin{tabular}{llllllll}
\hline \multirow{2}{*}{ Cooperating Teacher Characteristics } & \multicolumn{4}{c}{ Satisfaction } & \multirow{2}{*}{ Group Total } \\
\cline { 2 - 6 } & \multicolumn{2}{c}{ Dissatisfied } & Satisfied & & \\
\cline { 2 - 7 } & $M$ & $S D$ & $M$ & $S D$ & $M$ & $S D$ \\
\hline
\end{tabular}

I was permitted to miss school to travel with my cooperating teacher to professional meetings

$\begin{array}{llllll}4.59 & 1.66 & 5.48 & 1.10 & 5.34 & 1.24\end{array}$

My cooperating teacher gave me guidance regarding SAE visits* I had a positive relationship with my cooperating teacher

$\begin{array}{llllll}3.53 & 2.04 & 4.61 & 1.59 & 4.42 & 1.72\end{array}$

My cooperating teacher helped me with discipline issues

$\begin{array}{llllll}3.40 & 1.82 & 5.75 & .71 & 5.34 & 1.33\end{array}$

My cooperating teacher and university supervisor discussed my progress

$\begin{array}{llllll}3.50 & 1.82 & 5.35 & 1.03 & 5.03 & 1.38\end{array}$

*Reverse coded for data analysis

A $t$-test statistical procedure was used to determine if differences existed in the characteristics of cooperating teachers, when comparing individuals who were satisfied and dissatisfied with their student teaching experience. Differences in all of the cooperating teacher characteristics were found to be significant at $\alpha \leq .05$.

Those who were satisfied with their student teaching experience $(N=96, M=$ $5.01, S D=1.12)$ were in higher agreement that their cooperating teacher introduced their credentials to help establish their rapport compared to respondents who were dissatisfied with student teaching $(\mathrm{N}=20, M=3.70, S D=1.78)$. The $t$-test resulted in a $t$ value of 3.165, with 22.228 degrees of freedom. The difference exhibited a large effect (Cohen, 1988) (see Table 33). 
Individuals who were satisfied with student teaching $(N=96, \mathrm{M}=5.64, \mathrm{SD}=.84)$ rated the statement "my cooperating teacher was readily available to answer my questions" higher compared to individuals not satisfied with student teaching $(N=20, M$ $=3.75, S D=1.80)(t=4.576, d f=20.728)($ see Table 33$)$. The difference exhibited a large effect (Cohen, 1988).

Respondents who were satisfied with their student teaching experience $(N=96$, $M=5.77, S D=.51$ ) had a higher rating with the statement " my cooperating teacher supported my decisions in front of students" compared to respondents dissatisfied with student teaching $(N=20, M=3.70, S D=1.87)(t=4.923, d f=19.601)$ (see Table 33$)$. The difference had a large effect (Cohen, 1988).

Those respondents satisfied with student teaching $(N=96, M=5.72, S D=.76)$ had a higher rating for the statement "my cooperating teacher was willing to help me in any way possible," compared to individuals not satisfied with their experience $(N=20, M$ $=3.60, S D=1.54)(t=6.018, d f=20.997)($ see Table 33$)$. The difference had a large effect (Cohen, 1988).

People who were satisfied with student teaching $(N=94, M=4.26, S D=1.56)$ rated the statement "my cooperating teacher provided me with adequate guidance" when compared to those who were dissatisfied with student teaching $(N=20, M=3.60, S D=$ 1.54) $(t=5.058, d f=112)$ (see Table 33). The difference in the means exhibited a medium effect (Cohen, 1988).

Individuals who were satisfied with their student teaching experience $(N=96, M$ $=4.57, S D=.80)$ had a higher rating with regard to their cooperating teacher evaluating their performance each week compared to individuals dissatisfied $(N=20, M=3.25, S D$ 
$=1.71)(t=3.583, d f=20.535)($ see Table 33). The difference exhibited a medium effect (Cohen, 1988).

Satisfied individuals $(N=96, M=5.65, S D=4.60)$ had a higher agreement that their cooperating teacher encouraged them to go with him/her and students to FFA events and activities compared to dissatisfied individuals $(N=20, M=4.60, S D=1.82)(t=$ 2.52, $d f=20.535)$ (see Table 33). The difference exhibited a large effect (Cohen, 1988).

Respondents satisfied with student teaching $(N=96, S D=1.05, M=5.28)$ were in more agreement that their cooperating teacher provided feedback regarding their student teaching progress compared to individuals not satisfied with student teaching ( $N$ $=20, S D=1.43, M=3.50)(t=6.439, d f=20.480)($ see Table 33$)$. The difference in the means exhibited a large effect (Cohen, 1988).

Individuals who were satisfied with student teaching $(N=96, M=5.67, S D=.71)$ had a higher rating for the statement "my cooperating teacher had a positive attitude toward teaching" when compared to the rating of dissatisfied individuals $(N=20, S D=$ 1.79, $M=3.55)(t=5.202, d f=20.245)($ see Table 33). The effect exhibited by the difference in the means was large (Cohen, 1988).

Satisfied individuals $(N=96, M=5.65, S D=.68)$ agreed more with the statement "my cooperating teacher had a positive attitude toward students" than individuals not satisfied with student teaching $(N=20, M=4.25, S D=1.59)(t=3.864, d f=20.480)$ (see Table 33). The difference exhibited a large effect (Cohen, 1988).

Individuals who were satisfied with student teaching $(N=96, M=5.72, S D=.61)$ believed their cooperating teacher had a positive attitude toward the agricultural education profession more than dissatisfied individuals $(N=20, M=4.20, S D=1.77)(t$ 
$=3.801, d f=19.956)($ see Table 33). The difference exhibited a large effect (Cohen, 1988).

Those satisfied with their student teaching experience $(N=96, M=5.60, S D=$ .934) had a higher rating for the statement "my cooperating teacher created a good working atmosphere" compared to individuals dissatisfied with student teaching $(N=20$, $M=3.20, S D=1.82)(t=5.740, d f=21.123)($ see Table 33$)$. The difference exhibited a large effect (Cohen, 1988).

Respondents who were satisfied with their student teaching experience $(\mathrm{N}=91$, $M=5.48, S D=1.10$ ) had a higher rating for the statement "I was permitted to miss school to travel with my cooperating teacher to professional meetings" compared to individuals not satisfied with student teaching $N=17, M=4.59, S D=1.66)(t=2.137, d f$ =18.704) (see Table 33). The difference exhibited a medium effect (Cohen, 1988).

Satisfied individuals $(N=94, M=4.61 S D=1.59)$ believed their cooperating teacher provided them with more guidance regarding SAE visits compared to individuals not satisfied with student teaching $(N=19, M=3.53, S D=2.04)(t=2.180, d f=22.664)$ (see Table 33). The difference exhibited a small effect (Cohen, 1988).

Respondents who were satisfied $(N=96, \mathrm{M}=5.75, S D=.71)$ had a higher rating for the statement "I had a positive relationship with my cooperating teacher" compared to individuals dissatisfied with student teaching $(N=20, M=3.40, S D=1.81)(t=5.691, d f$ $=20.225)$ (see Table 33). The difference exhibited a large effect (Cohen, 1988).

People who were satisfied with student teaching $(N=96, M=5.35, S D=1.03)$ had a higher rating for the statement "my cooperating teacher helped me with discipline issues" compared to individuals dissatisfied with their experience $(N=20, M=3.50, S D$ 
$=1.82)(t=4.410, d f=21.576)($ see Table 33$)$. The difference exhibited a large effect (Cohen, 1988).

Satisfied individuals $(N=95, M=5.54, S D=.76)$ felt their cooperating teacher and university supervisor discussed their progress more than individuals who were dissatisfied with student teaching $(N=20, M=4.40, S D=1.27)(t=3.853, d f=21.895)$ (see Table 33). The effect exhibited by the difference was large (Cohen, 1988).

Table 33

Comparison of Means of Cooperating Teacher Characteristics of Satisfied and Dissatisfied Individuals

\begin{tabular}{|c|c|c|c|c|}
\hline \multirow[t]{2}{*}{ Cooperating Teacher Characteristics } & \multicolumn{2}{|c|}{$\begin{array}{l}\text { Student Teaching } \\
\text { Satisfaction }\end{array}$} & \multirow[b]{2}{*}{$t$} & \multirow[b]{2}{*}{$d f$} \\
\hline & $\begin{array}{c}\text { Dissatisfied } \\
M \\
\end{array}$ & $\begin{array}{c}\text { Satisfied } \\
\qquad M\end{array}$ & & \\
\hline $\begin{array}{l}\text { My cooperating teacher introduced my } \\
\text { credentials to help establish my rapport } \\
\text { with the students }\end{array}$ & 3.70 & 5.01 & $3.165^{*}$ & 22.228 \\
\hline $\begin{array}{l}\text { My cooperating teacher was readily } \\
\text { available to answer my questions }\end{array}$ & 3.75 & 5.64 & $4.576^{*}$ & 20.728 \\
\hline $\begin{array}{l}\text { My cooperating teacher supported my } \\
\text { decisions in front of students }\end{array}$ & 3.70 & 5.77 & $4.923^{*}$ & 19.601 \\
\hline $\begin{array}{l}\text { My cooperating teacher was willing to help } \\
\text { me in any way possible }\end{array}$ & 3.60 & 5.72 & $6.018^{*}$ & 20.997 \\
\hline $\begin{array}{l}\text { My cooperating teacher provided me with } \\
\text { adequate guidance* }\end{array}$ & 2.30 & 4.26 & $5.058^{*}$ & 112 \\
\hline $\begin{array}{l}\text { My cooperating teacher evaluated my } \\
\text { performance each week }\end{array}$ & 3.25 & 4.57 & $3.583^{*}$ & 114 \\
\hline $\begin{array}{l}\text { My cooperating teacher encouraged me to } \\
\text { go with him/her and students to FFA events } \\
\text { and activities }\end{array}$ & 4.60 & 5.65 & $2.523^{*}$ & 20.535 \\
\hline $\begin{array}{l}\text { My cooperating teacher provided feedback } \\
\text { about my progress during student teaching }\end{array}$ & 3.50 & 5.28 & $6.439 *$ & 114 \\
\hline
\end{tabular}


Table 33 (Continued)

Comparison of Means of Cooperating Teacher Characteristics of Satisfied and

Dissatisfied Individuals

\begin{tabular}{|c|c|c|c|c|}
\hline \multirow[t]{2}{*}{ Cooperating Teacher Characteristics } & \multicolumn{2}{|c|}{$\begin{array}{l}\text { Student Teaching } \\
\text { Satisfaction }\end{array}$} & \multirow[b]{2}{*}{$t$} & \multirow[b]{2}{*}{$d f$} \\
\hline & $\begin{array}{c}\text { Dissatisfied } \\
M \\
\end{array}$ & $\begin{array}{l}\text { Satisfied } \\
\qquad M\end{array}$ & & \\
\hline $\begin{array}{l}\text { My cooperating teacher had a positive } \\
\text { attitude toward teaching }\end{array}$ & 3.55 & 5.67 & $5.202 *$ & 20.245 \\
\hline $\begin{array}{l}\text { My cooperating teacher had a positive } \\
\text { attitude toward students }\end{array}$ & 4.25 & 5.65 & $3.864 *$ & 20.480 \\
\hline $\begin{array}{l}\text { My cooperating teacher had a positive } \\
\text { attitude toward the agricultural education } \\
\text { profession }\end{array}$ & 4.20 & 5.72 & $3.801 *$ & 19.956 \\
\hline $\begin{array}{l}\text { My cooperating teacher created a good } \\
\text { working atmosphere }\end{array}$ & 3.20 & 5.60 & $5.740 *$ & 21.123 \\
\hline $\begin{array}{l}\text { I was permitted to miss school to travel } \\
\text { with my cooperating teacher to professional } \\
\text { meetings }\end{array}$ & 4.59 & 5.48 & $2.137 *$ & 18.704 \\
\hline $\begin{array}{l}\text { My cooperating teacher gave me guidance } \\
\text { regarding SAE visits* }\end{array}$ & 3.53 & 4.61 & $2.180 *$ & 22.664 \\
\hline $\begin{array}{l}\text { I had a positive relationship with my } \\
\text { cooperating teacher }\end{array}$ & 3.40 & 5.75 & $5.691 *$ & 20.225 \\
\hline $\begin{array}{l}\text { My cooperating teacher helped me with } \\
\text { discipline issues }\end{array}$ & 3.50 & 5.35 & $4.410 *$ & 21.576 \\
\hline $\begin{array}{l}\text { My cooperating teacher and university } \\
\text { supervisor discussed my progress }\end{array}$ & 4.40 & 5.54 & $3.853^{*}$ & 21.895 \\
\hline
\end{tabular}

$* \alpha \leq .05$

The means of the Likert type statements addressing university supervisor characteristics were calculated for those satisfied and dissatisfied with their student teaching experience. Individuals dissatisfied with their student teaching experience rated the statement "my university supervisor provided constructive feedback" with a mean of 
4.60 and a standard deviation of 1.57. Dissatisfied individuals rated the same statement with a mean of 5.42 and a standard deviation of 1.05 . The mean of the group equaled 5.28, with a standard deviation of 1.19 (see Table 34).

Those who were dissatisfied with student teaching rated the statement "my university supervisor provided me with positive feedback" with a mean of 5.05 and standard deviation of 1.05. The satisfied individuals rated the statement with a mean of 5.50 and a standard deviation of .94 . The group had a mean of 5.42 with a standard deviation of .97 (see Table 34).

Those dissatisfied with student teaching rated the statement "my university supervisor offered suggestions for improving my teaching techniques" with a mean equaling 5.00 and a standard deviation of 1.17. The satisfied individuals rated the statement with a mean of $5.34(S D=.97)$. The group had a mean of 5.28 and a standard deviation of 1.01 (see Table 34).

Dissatisfied respondents gave the statement "my university supervisor created a positive atmosphere during his/her visits" a mean of $4.70(S D=1.53)$. Respondents satisfied with student teaching rated the statement with a mean 5.36 and a standard deviation of 1.11). The group mean was $5.25(S D=1.26)$ (see Table 34).

Respondents dissatisfied with student teaching rated the statement "I had a positive relationship with my university supervisor" with a mean of 4.55 and a standard deviation of 1.85. Satisfied individuals rated the statement with a mean of $5.52(S D=$ 1.04). The group mean was 5.35, with a standard deviation of 1.26 (see Table 34). Respondents who were dissatisfied with student teaching rated the statement "my university supervisor made me aware he/she was available in any way to help me have a 
good student teaching experience" with a mean of 4.50 and standard deviation equaling 1.67. The satisfied individuals rated the same statement with a mean of 5.26 and a standard deviation of 1.06. The group had a mean value of 5.13 with a standard deviation of 1.21 (see Table 34).

Table 34

University Supervisor Variable for Satisfied and Dissatisfied Individuals

\begin{tabular}{|c|c|c|c|c|c|c|}
\hline \multirow[t]{3}{*}{ University Supervisor Variables } & \multicolumn{4}{|c|}{ Satisfaction } & \multicolumn{2}{|c|}{ Group Total } \\
\hline & \multicolumn{2}{|c|}{ Dissatisfied } & \multicolumn{2}{|c|}{ Satisfied } & \multirow[b]{2}{*}{$M$} & \multirow[b]{2}{*}{$S D$} \\
\hline & $M$ & $S D$ & $M$ & $S D$ & & \\
\hline $\begin{array}{l}\text { My university supervisor provided } \\
\text { constructive feedback }\end{array}$ & 4.60 & 1.57 & 5.42 & 1.05 & 5.28 & 1.19 \\
\hline $\begin{array}{l}\text { My university supervisor provided } \\
\text { positive feedback }\end{array}$ & 5.05 & 1.05 & 5.50 & .94 & 5.42 & .97 \\
\hline $\begin{array}{l}\text { My university supervisor offered } \\
\text { suggestions for improving my teaching } \\
\text { techniques }\end{array}$ & 5.00 & 1.17 & 5.34 & .97 & 5.28 & 1.01 \\
\hline $\begin{array}{l}\text { My university supervisor created a } \\
\text { positive atmosphere during his/her } \\
\text { visits }\end{array}$ & 4.70 & 1.53 & 5.36 & 1.11 & 5.25 & 1.21 \\
\hline $\begin{array}{l}\text { I had a positive relationship with my } \\
\text { university supervisor* }\end{array}$ & 4.55 & 1.85 & 5.52 & 1.04 & 5.35 & 1.26 \\
\hline $\begin{array}{l}\text { Yy university supervisor made me } \\
\text { ware he she was available in any way } \\
\text { help me have a good student } \\
\text { eaching experience }\end{array}$ & 4.50 & 1.67 & 5.26 & 1.06 & 5.13 & 1.21 \\
\hline
\end{tabular}

*Reverse coded for data analysis

A $t$-test statistical procedure was used to determine if differences existed in the characteristics of university supervisors, when comparing individuals who were satisfied and dissatisfied with their student teaching experience. Two of the university supervisor characteristics were found to be significant at $\alpha \leq .05$. 
Satisfied respondents $(N=96, M=5.42, S D=1.05)$ gave a higher rating for the statement "my university supervisor provided constructive feedback" compared to dissatisfied individuals $(N=20, M=4.60, S D=1.57)(t=2.225, \mathrm{df}=22.691)($ see Table 35). The difference exhibited a medium effect (Cohen, 1988). Individuals who were satisfied with student teaching ( $N=96, M=5.42, S D=1.05$ ) had higher rating for the statement "I had a positive relationship with my university supervisor" compared to individuals who were dissatisfied $(N=20, M=4.55, S D=1.85)(t=2.275, \mathrm{df}=21.548)$ (see Table 35). The difference exhibited a medium effect (Cohen, 1988).

Table 35

Comparison of Means of University Supervisor Characteristics of Satisfied and Dissatisfied Individuals

University Supervisor Characteristics Student Teaching Satisfaction Satisfied Dissatisfied

\begin{tabular}{lcccc}
\cline { 2 - 5 } & $M$ & $M$ & $t$ & $d f$ \\
\hline $\begin{array}{l}\text { My university supervisor provided } \\
\text { constructive feedback }\end{array}$ & 5.42 & 4.60 & $2.225^{*}$ & 22.691 \\
$\begin{array}{l}\text { I had a positive relationship with my } \\
\text { university supervisor }\end{array}$ & 5.42 & 4.55 & $2.275^{*}$ & 21.548 \\
\hline$* \leq .05$ & & & &
\end{tabular}

Research Question Three

Research question three dealt with the factors participants identified as influences on their decision to teach agriculture. Respondents were asked to respond to the survey question by ranking the factors from one to five, with one being the most influential. For the purpose of data analysis, the responses were reverse coded in order to compute a sum. The sums were then ordered from highest to lowest to determine the top influential factors. 
The top rated factor influencing an individual to teach agriculture was their agriculture teacher. The second most influential factor was an individual's agricultural background. The third factor was FFA involvement. The fourth influential factor was an individual's high school agriculture program involvement. The fifth influential factor was the individual's family (see Table 36).

\section{Research Question Four}

Research question four addressed the level of participation in the National FFA Organization for those who cited "FFA involvement" as a factor influencing their decision to teach agriculture versus respondents who did not cite "FFA involvement" as a factor. To define the level of participation of the respondents, the researchers quantified the questions associated with FFA involvement, which included chapter FFA offices, state FFA offices, leadership conferences, Career Development Events, and FFA activities.

Of the respondents who were currently teaching or had taught agriculture, 17 respondents $(18.7 \%)$ did not serve as a chapter officer. Twenty-four people $(26.4 \%)$ served in one chapter office. Thirty individuals (33.0\%) served two chapter offices, 14 individuals $(15.4 \%)$ served 3 chapter offices, four people $(4.4 \%)$ served four chapter offices, one person (1.1\%) served in five chapter offices, and one individual $(1.1 \%)$ served in six chapter offices $($ Mode $=2)$ (see Table 37). 
Table 36

Factors Influencing Participants Decision to Teach Agriculture

\begin{tabular}{|c|c|}
\hline Reasons to teach & Ranking \\
\hline My agriculture teacher & 1 \\
\hline Agricultural background & 2 \\
\hline FFA involvement & 3 \\
\hline High school agricultural program involvement & 4 \\
\hline Family & 5 \\
\hline Other agriculture teachers & 6 \\
\hline University faculty & 7 \\
\hline 4-H involvement & 8 \\
\hline Other people in the agricultural education profession & 8 \\
\hline Involvement in other agricultural organizations & 9 \\
\hline Friends & 10 \\
\hline Help students achieve goals & 11 \\
\hline Wanted to be a teacher & 12 \\
\hline My degree was in Ag. Ed as a backup plan & 13 \\
\hline Scholarship & 13 \\
\hline Attending NC FFA camp & 13 \\
\hline Job offer & 13 \\
\hline Interest in small and large animals & 13 \\
\hline Student teaching experience & 13 \\
\hline Mentor students & 13 \\
\hline No other jobs in area & 13 \\
\hline Wanted to teach about animals & 13 \\
\hline As an alternative to vet school, teach animal science & 13 \\
\hline Scholarship for teaching 4 years & 14 \\
\hline Church & 15 \\
\hline Extension not hiring & 16 \\
\hline I enjoy teaching & 16 \\
\hline Camp counselor for FFA camp & 17 \\
\hline Fate & 17 \\
\hline Serving as an influence to younger FFA members in my chapter & 17 \\
\hline College teaching courses & 17 \\
\hline
\end{tabular}


Table 37

Number of Chapter FFA Offices held by Individuals who are Currently Teaching or who Taught Agricultural Education in the Past

\begin{tabular}{ccc}
\hline Number of Chapter Offices & $N$ & $\%$ \\
\hline 0 & 17 & 18.7 \\
1 & 24 & 26.4 \\
2 & 30 & 33.0 \\
3 & 14 & 15.4 \\
4 & 4 & 4.4 \\
5 & 1 & 1.1 \\
6 & 1 & 1.1 \\
\hline Total & 91 & 100.0 \\
\hline
\end{tabular}

Of the individuals who were currently teaching or had taught agriculture, 76 respondents $(83.5 \%)$ did not serve as a state FFA officer. Fifteen individuals (16.5\%) had held one state FFA office (Mode $=0)($ see Table 38$)$.

Table 38

Number of State FFA Offices held by Current Individuals who are Currently Teaching or who Taught Agricultural Education in the Past

\begin{tabular}{ccc}
\hline Number of State Offices & $N$ & $\%$ \\
\hline 0 & 76 & 83.5 \\
1 & 15 & 16.5 \\
\hline Total & 91 & 100.0 \\
\hline
\end{tabular}

The leadership conferences identified by respondents in question 61 of the survey were quantified. Of the current teachers and past teachers, 22 respondents $(24.2 \%)$ had not attended any leadership activities. Ten people (11.0\%) had attended one leadership 
conference. Fifteen individuals (16.5\%) had attended two leadership conferences. Thirteen people (14.3\%) had attended three leadership conferences, 13 individuals had attended four leadership conferences, six respondents (6.6\%) had attended five leadership conferences, three individuals (3.3\%) attended six leadership activities, two people (2.2\%) attended eight leadership activities, and one person (1.1\%) attended nine leadership activities (see Table 39).

Table 39

Number of Leadership Activities attended by Individuals who are Currently Teaching or who Taught Agricultural Education in the Past

\begin{tabular}{ccc}
\hline Number & $N$ & $\%$ \\
\hline 0 & 22 & 24.2 \\
1 & 10 & 11.0 \\
2 & 15 & 16.5 \\
3 & 13 & 14.3 \\
4 & 13 & 14.3 \\
5 & 6 & 6.6 \\
6 & 3 & 3.3 \\
7 & 6 & 6.6 \\
8 & 2 & 2.2 \\
9 & 1 & 1.1 \\
\hline Total & 61 & 100.0 \\
\hline
\end{tabular}

The number of career development events (CDE) was calculated for individuals who were are currently teaching or who taught agricultural Education in the past. Fourteen people (15.4\%) had not competed in CDEs. Five people (5.5\%) had competed in one career development event. Twelve respondents (13.2\%) had competed in two career development events. Twelve people (13.2\%) had competed in two CDEs. Seven 
people $(7.7 \%)$ had competed in three career development events, seven people (7.7\%) had competed in four CDEs, eight individuals $(8.8 \%)$ had competed in five career development events, 11 respondents (12.1\%) had competed in six career development events, and seven people (7.7\%) had competed in seven competitions. Six people (6.6\%) had competed in eight CDEs, one person (1.1\%) had competed in nine events, one individual (1.1\%) had competed in ten CDEs, four individuals (4.4\%) competed in 11 competitions, three people (3.3\%) competed in 12 career development events, one person (1.1\%) competed in $13 \mathrm{CDEs}$, one person (1.1\%) competed in 14 career development events, one person (1.1\%) competed in $15 \mathrm{CDEs}$, one individual (1.1\%) competed in 16 CDEs, one respondent $(1.1 \%)$ competed in 18 career development events, and one respondent $(1.1 \%)$ competed in 19 CDEs $($ Mode $=0)($ see Table 40$)$.

The number of FFA activities from question 63 of the survey instrument was totaled for all individuals who were teaching or had taught agriculture. Four respondents (4.4\%) had not taken part in FFA activities addressed in question 63. Five individuals (5.5\%) had been to one FFA activity. Seventeen people (18.7\%) had participated in two FFA activities, 35 respondents (38.5\%) had participated in three FFA activities, 16 individuals (17.6\%) had participated in four FFA activities, eight people (8.8\%) had participated in five FFA activities, and six people (6.6\%) had participated in six FFA activities $($ Mode $=3)($ see Table 41$)$. 
Table 40

Number of CDEs Competitions completed by Individuals who are Currently Teaching or who Taught Agricultural Education in the Past

\begin{tabular}{|c|c|c|}
\hline Number & $N$ & $\%$ \\
\hline 0 & 14 & 15.4 \\
\hline 1 & 5 & 5.5 \\
\hline 2 & 12 & 13.2 \\
\hline 3 & 7 & 7.7 \\
\hline 4 & 7 & 7.7 \\
\hline 5 & 8 & 8.8 \\
\hline 6 & 11 & 12.1 \\
\hline 7 & 7 & 7.7 \\
\hline 8 & 6 & 6.6 \\
\hline 9 & 1 & 1.1 \\
\hline 10 & 1 & 1.1 \\
\hline 11 & 4 & 4.4 \\
\hline 12 & 3 & 3.3 \\
\hline 14 & 1 & 1.1 \\
\hline 15 & 1 & 1.1 \\
\hline 16 & 1 & 1.1 \\
\hline 18 & 1 & 1.1 \\
\hline 19 & 1 & 1.1 \\
\hline Total & 91 & 100.0 \\
\hline
\end{tabular}


Table 41

Number of FFA Activities Participated in by Individuals who are Currently Teaching or who Taught Agricultural Education in the Past

\begin{tabular}{rcc}
\hline Number & $N$ & $\%$ \\
\hline 0 & 4 & 4.4 \\
1 & 5 & 5.5 \\
2 & 17 & 18.7 \\
3 & 35 & 38.5 \\
4 & 16 & 17.6 \\
5 & 8 & 8.8 \\
6 & 6 & 6.6 \\
\hline Total & 91 & 100.0 \\
\hline
\end{tabular}

A $t$-test statistical procedure was used to determine if statistical differences existed in the means of activities that composed FFA involvement for the two groups. Three of the FFA components were significant at $\alpha \leq .05$

The mean number of chapter offices held by individuals who did not cite "FFA involvement" as an influence on their decision to teach was .90 with a standard deviation of 1.01. The mean number of chapter offices held by individuals who cited "FFA involvement" as an influence on their decision to teach was 2.05 with a standard deviation of 1.17 (see Table 42). The independent $t$-test results $(t=-4.573, d f=89)$ were significant at $\alpha \leq .05$ (see Table 42). The difference between the means exhibited a large effect (Cohen, 1988).

The mean number of leadership conferences attended by individuals who did not cite "FFA involvement" as an influence on their decision to teach was 1.41 with a standard deviation of 1.84 . The mean number of leadership conferences attended by 
individuals who cited "FFA involvement" as an influence on their decision to teach was 3.31 with a standard deviation of 2.31 (see Table 42 ). The independent $t$-test results ( $t=-$ 3.872, $d f=89$ ) were significant at $\alpha \leq .05$ (see Table 43). The difference between the means exhibited a small effect (Cohen, 1988).

The mean number of FFA activities attended by individuals who did not cite "FFA involvement" as an influence was $2.48(S D=1.53)$. Those who did cite "FFA involvement" had attended a mean of $3.42 \mathrm{FFA}$ activities $(S D=1.22)$ (see Table 42). The $t$-test results $(t=-3.141, d f=89)$ were significant at $\alpha \leq .05$ (see Table 43). The difference between the means exhibited a medium effect (Cohen, 1988).

Table 42

Differences in FFA Involvement between Individuals who did and did not Cite "FFA Involvement" as a Factor Influencing an Individual to Teach Agriculture

FFA Involvement Influence on Teaching Agriculture

\begin{tabular}{lrrrr} 
& \multicolumn{2}{c}{ No } & \multicolumn{2}{c}{ Yes } \\
\cline { 2 - 5 } & \multicolumn{1}{c}{$M$} & \multicolumn{1}{c}{$S D$} & \multicolumn{1}{c}{ M } \\
\hline Number of Chapter Offices & .90 & 1.01 & 2.05 & 1.17 \\
Number of State Offices & .10 & .31 & .19 & .40 \\
Number of Leadership Conferences & 1.41 & 1.84 & 3.31 & 2.31 \\
Number of CDE Events & 4.17 & 4.90 & 5.50 & 3.96 \\
Number of FFA Activities & 2.48 & 1.53 & 3.42 & 1.22 \\
\hline
\end{tabular}


Table 43

Comparison of Means of FFA Involvement

\begin{tabular}{lccccc}
\hline \multirow{2}{*}{ Type of FFA Involvement } & \multicolumn{3}{c}{$\begin{array}{c}\text { Influence on Teaching } \\
\text { Agriculture }\end{array}$} & & \\
\cline { 2 - 4 } & \multicolumn{2}{c}{ No } & Yes & & \\
\cline { 2 - 4 } & $M$ & $M$ & $d f$ & $t$ \\
\hline Number of Chapter Offices & .90 & 1.01 & 89 & $-4.573^{*}$ \\
Number of Leadership Conferences & 1.41 & 1.84 & 89 & $-3.872^{*}$ \\
Number of FFA Activities & 2.48 & 3.42 & 89 & $-3.141^{*}$ \\
\hline
\end{tabular}

$* \alpha \leq .05$

Research Question Five

Research question four addressed the differences in the level of participation in 4-H for those who cited "4-H involvement" as a factor influencing their decision to teach agriculture compared to individuals who did not cited "4-H involvement" as a factor. To define the level of participation of the respondents, the researchers quantified the questions associated with 4-H involvement including the number of 4-H offices, number of state 4-H offices, and number of 4-H activities.

Two respondents $(4.3 \%)$ had not served as a $4-\mathrm{H}$ club officer. Fifteen individuals $(32.6 \%)$ had served in one $4-\mathrm{H}$ club office. Eleven people $(23.9 \%)$ had served in two 4-H club offices. Eight people (17.4\%) had served three offices; six people (13.0\%) had served four offices; and four people $(8.7 \%)$ had served five $4-\mathrm{H}$ club offices $($ Mode $=1$ ) (see Table 44). 
Table 44

Number of 4-H Club Offices Held by Individuals who did and did not Cite "4-H Involvement" as a Factor Influencing an Individual to Teach Agriculture

\begin{tabular}{ccc}
\hline Number of 4-H Offices & $N$ & $\%$ \\
\hline 0 & 2 & 4.3 \\
1 & 15 & 32.6 \\
2 & 11 & 23.9 \\
3 & 8 & 17.4 \\
4 & 6 & 13.0 \\
5 & 4 & 8.7 \\
\hline Total & 46 & 100.0 \\
\hline
\end{tabular}

Forty-five individuals $(97.8 \%)$ had not served as a 4-H state officer. One person $(2.2 \%)$ had served in one state $4-\mathrm{H}$ office $($ Mode $=0)($ see Table 45$)$.

Table 45

Number of 4-H State Offices Held by Individuals who did and did not Cite "4-H Involvement” as a Factor Influencing an Individual to Teach Agriculture

\begin{tabular}{ccc}
\hline Number of 4-H State Offices & $N$ & $\%$ \\
\hline 0 & 45 & 97.8 \\
1 & 1 & 2.2 \\
\hline Total & 46 & 100.0 \\
\hline
\end{tabular}

Two respondents $(4.3 \%)$ had not attended any $4-\mathrm{H}$ activities. Four people $(8.7 \%)$ had attended one 4-H activity. Eleven people (23.9\%) had attended two 4-H activities, three people $(6.5 \%)$ had attended three activities, six people $(13.0 \%)$ had been to four activities, four people $(8.7 \%)$ had attended five activities, three people $(6.5 \%)$ had been to six activities, two people (4.3\%) had been to seven $4-\mathrm{H}$ activities, three people $(6.5 \%)$ 
had attended eight activities, one person $(2.2 \%)$ had attended nine activities, four people $(8.7 \%)$ had attended ten activities, and three people $(6.5 \%)$ had attended $114-\mathrm{H}$ activities $($ Mode $=2)($ see Table 46).

Table 46

Number of 4-H Activities Participated in by Individuals who did and did not Cite "4-H Involvement” as a Factor Influencing an Individual to Teach Agriculture

\begin{tabular}{ccc}
\hline Number of 4-H Activities & $N$ & $\%$ \\
\hline 0 & 2 & 4.3 \\
1 & 4 & 8.7 \\
2 & 11 & 23.9 \\
3 & 3 & 6.5 \\
4 & 6 & 13.0 \\
5 & 4 & 8.7 \\
6 & 3 & 6.5 \\
7 & 2 & 4.3 \\
8 & 3 & 6.5 \\
9 & 1 & 2.2 \\
10 & 4 & 8.7 \\
11 & 3 & 6.5 \\
\hline Total & 3 & 100.0 \\
\hline
\end{tabular}

The mean number of 4-H club offices held by individual who did not cite "4-H involvement" as an influence on their decision to teach agriculture was 1.79 with a standard deviation of 1.23 (see Table 47). The mean number of 4-H club offices held by individual who cited "4-H involvement" as an influence on their decision to teach agriculture was 2.94 with a standard deviation of 1.25 (see Table 47). The independent $t$ - 
test results $(t=-3.041, \mathrm{df}=43)$ were significant at $\alpha \leq .05$ (see Table 48). The difference between the means exhibited a medium effect (Cohen, 1988).

The mean number of 4-H activities attended by individuals who did not cite "4-H involvement" as an influence on their decision to teach agriculture was 3.79 with a standard deviation of 3.36 (see Table 47). The mean number of $4-\mathrm{H}$ activities attended by individuals who cited "4-H involvement" as an influence on their decision to teach agriculture was 6.29 with a standard deviation of 2.71 (see Table 47). The independent $t$ test results $(t=-2.603, d f=43)$ were significant at $\alpha \leq .05$ (see Table 48). The difference between the means exhibited a small effect (Cohen, 1988).

Table 47

Differences in 4-H Involvement between Individuals who did and did not Cite "4-H Involvement” as a Factor Influencing an Individual to Teach Agriculture

\begin{tabular}{lrrrr}
\hline \multirow{2}{*}{ 4-H Involvement } & \multicolumn{3}{c}{ Influence on Teaching Agriculture } \\
\cline { 2 - 5 } & \multicolumn{3}{c}{ No } & \multicolumn{2}{c}{ Yes } \\
\cline { 2 - 5 } & \multicolumn{1}{c}{$M$} & $S D$ & \multicolumn{1}{c}{ SD } \\
\hline Number of 4-H Club Offices & 1.79 & 1.23 & 2.94 & 1.25 \\
Number of 4-H State Offices & .00 & .00 & .06 & .24 \\
Number of 4-H Activities & 3.79 & 3.36 & 6.29 & 2.71 \\
\hline
\end{tabular}


Table 48

Comparison of Means of 4-H Involvement

Type of 4-H Involvement

Influence on Teaching

Agriculture

\begin{tabular}{lcccc} 
& No & Yes & & \\
& $M$ & $M$ & $d f$ & $t$ \\
\hline Number of Club Offices & 1.79 & 2.94 & 43 & $-3.041^{*}$ \\
Number of 4-H Activities & 3.79 & 6.29 & 43 & $-2.603^{*}$ \\
\hline
\end{tabular}

$* \alpha \leq .05$

Research Question Six

Research question six addressed the factors influencing the teaching decision of

those who never taught agriculture. Respondents were asked to respond to the survey

question by ranking the factors from one to five, with one being the most influential. For

purpose of data analysis, the responses were reverse coded in order to compute a sum.

The sums were then ordered from highest to lowest to determine the top influential factors.

The most influential factor on an individual's decision not to teach agriculture was their student teaching experience. The second most influential factor was demands of the job. The third most common influence on an individual's decision to not teach agriculture was low salary. The fourth most influential factor was no teaching jobs in the area. The fifth most common factor influencing the respondents' decisions to not teach agriculture was time requirements of the job (see Table 49). 
Table 49

Factors Influencing Participants’ Decision not to Teach Agriculture

\begin{tabular}{lc}
\hline Reasons not to teach & Rank \\
\hline Student teaching experience & 1 \\
Demands of the job & 2 \\
Low salary & 3 \\
No teaching jobs in area & 4 \\
Time requirements & 5 \\
Another opportunity more desirable & 6 \\
Teaching expectations too high & 7 \\
Extended employment & 8 \\
Student discipline & 8 \\
Offered job upon graduation & 8 \\
Students very rude and disrespectful & 8 \\
Graduate school & 10 \\
Student behavior & 11 \\
No ag ed jobs currently available & 11 \\
Lack of administrative support & 11 \\
Other career goals & 11 \\
Didn't want to teach & 13 \\
Timing of graduation & 13 \\
Got job as extension agent & 12 \\
Atmosphere in my location rough population to serve & 8 \\
\hline
\end{tabular}

\section{Research Question Seven}

Research question seven sought to determine when the respondents who never taught agriculture $(N=26)$ decided not to teach. Fifteen individuals $(57.6 \%)$ disagreed that they wanted to teach agriculture when they started college (see Table 50). Eleven 
individuals (42.3\%) agreed that they wanted to teach agriculture when they started college (see Table 50).

Of the respondents who never taught agriculture $(N=26)$, eight people $(30.8 \%)$ disagreed that they wanted to teach agriculture before they enrolled in teaching methods (see Table 50). Eighteen individuals (69.2\%) agreed they wanted to teach agriculture before they enrolled in teaching methods (see Table 50).

Six of the respondents $(23.0 \%)$ who never taught agriculture $(N=26)$ disagreed they wanted to teach agriculture before their student teaching experience. Twenty respondents (76.9\%) agreed they wanted to teach agriculture before their student teaching experience (see Table 50).

When looking at the respondents who never taught agriculture, 13 individuals (52.0\%) disagreed with the statement "I wanted to teach agriculture after their student teaching experience" (see Table 50). Twelve individuals (48.0\%) agreed they wanted to teach agriculture after their student teaching experience (see Table 50). 
Table 50

Timing of Teaching Decision for Individuals who Never Taught Agricultural Education

\begin{tabular}{|c|c|c|c|c|c|c|c|c|c|c|c|c|}
\hline & \multicolumn{2}{|c|}{$\begin{array}{l}\text { Strongly } \\
\text { Disagree }\end{array}$} & \multicolumn{2}{|c|}{$\begin{array}{l}\text { Moderately } \\
\text { Disagree }\end{array}$} & \multicolumn{2}{|c|}{$\begin{array}{l}\text { Slightly } \\
\text { Disagree }\end{array}$} & \multicolumn{2}{|c|}{$\begin{array}{l}\text { Slightly } \\
\text { Agree }\end{array}$} & \multicolumn{2}{|c|}{$\begin{array}{l}\text { Moderately } \\
\text { Agree }\end{array}$} & \multicolumn{2}{|c|}{$\begin{array}{l}\text { Strongly } \\
\text { Agree }\end{array}$} \\
\hline & $N$ & $\%$ & $N$ & $\%$ & $N$ & $\%$ & $N$ & $\%$ & $N$ & $\%$ & $N$ & $\%$ \\
\hline $\begin{array}{l}\text { I wanted to teach agriculture when I started } \\
\text { college }\end{array}$ & 9 & 34.6 & 3 & 11.5 & 3 & 11.5 & 2 & 7.7 & 1 & 3.8 & 8 & 30.8 \\
\hline $\begin{array}{l}\text { I wanted to teach agriculture before I enrolled } \\
\text { in teaching methods }\end{array}$ & 2 & 7.7 & 2 & 7.7 & 4 & 15.4 & 3 & 11.5 & 4 & 15.4 & 11 & 42.3 \\
\hline $\begin{array}{l}\text { I wanted to teach agriculture before my student } \\
\text { teaching experience }\end{array}$ & 2 & 7.7 & 1 & 3.8 & 3 & 11.5 & 5 & 19.2 & 4 & 15.4 & 11 & 42.3 \\
\hline $\begin{array}{l}\text { I wanted to teach agriculture after my student } \\
\text { teaching experience* }\end{array}$ & 4 & 16.0 & 2 & 8.0 & 7 & 28.0 & 2 & 8.0 & 1 & 4.0 & 9 & 36.0 \\
\hline
\end{tabular}




\section{Research Question Eight}

Individuals who were not currently teaching agriculture were asked to identify their current occupation. Seven individuals (14.89\%) were in the field of Extension. Working for the Natural Resources Conservation Service (NRCS) was the occupation of five respondents (10.64\%). Four participants (8.51\%) were employed by an agricultural business. Four individuals $(8.51 \%)$ were graduate students, and four respondents (8.51\%) were both agriculture teachers and graduate students (see Table 51).

\section{Table 51}

Occupation Status of those not Teaching Agriculture

\begin{tabular}{lcc}
\hline Occupation & $N$ & $\%$ \\
\hline Extension & 7 & 14.89 \\
NRCS & 5 & 10.64 \\
Agricultural business & 4 & 8.51 \\
Graduate student & 4 & 8.51 \\
Agriculture teacher and graduate student & 4 & 8.51 \\
Middle school teacher & 2 & 4.26 \\
Unemployed & 2 & 4.26 \\
Farm Service Agency (FSA) & 1 & 2.13 \\
Science Teacher & 1 & 2.13 \\
Teacher of half agriculture and half science & 1 & 2.13 \\
Permanent substitute & 1 & 2.13 \\
Teacher of half agriculture and half technical & & \\
education & 1 & 2.13 \\
Teacher of Electronics & 1 & 2.13 \\
Recruiter for college of agriculture & 1 & 2.13 \\
Nursing student & 1 & 2.13 \\
Nursery/ greenhouse operator & 1 & 2.13 \\
General contractor & 1 & 2.13 \\
\hline
\end{tabular}


Table 51 (Continued)

Occupation Status of those not Teaching Agriculture

\begin{tabular}{lll}
\hline Occupation & $N$ & $\%$ \\
\hline $\begin{array}{l}\text { Certification and training specialist for NC } \\
\text { Department of Agriculture }\end{array}$ & 1 & 2.13 \\
$\begin{array}{l}\text { Community college instructor/horticulture } \\
\text { department chair }\end{array}$ & 1 & 2.13 \\
WV Conservation Agency & 1 & 2.13 \\
Conservation district & 1 & 2.13 \\
Librarian, summer school instructor & 1 & 2.13 \\
Ag. Choice Farm Credit Loan Officer & 1 & 2.13 \\
Travel & 1 & 2.13 \\
$7^{\text {th }}$ grade science switching to extension & 1 & 2.13 \\
Americorps Vista volunteer & 1 & 2.13 \\
\hline
\end{tabular}

\section{Research Question Nine}

Some of the individuals who had taught agriculture left teaching. Research question nine addressed the reasons why those individuals decided to leave the agricultural teaching field. Respondents were asked to respond to the survey question by ranking the factors from one to five, with one being the most influential. For the purpose of data analysis, the responses were reverse coded in order to compute a sum. The sums were then ordered from highest to lowest to determine the top influential factors.

The most common reason for leaving teacher was lack of administrative support (see Table 52). The second most common influence on the respondents' decision to leave teaching was low salary. The third most common influence was time requirements. The fourth most influential reason was no other available jobs in the area. The fifth most 
common reason included both lack of success as a teacher and too many demands other than teaching (see Table 52).

Table 52

Factors Influencing an Individual's Decision to Leave Teaching Agriculture

\begin{tabular}{lc}
\hline Reason left teaching & Ranking \\
\hline Lack of administrative support & 1 \\
Low salary & 2 \\
Time requirements & 3 \\
No other available jobs in area & 4 \\
Unsuccessful as a teacher & 5 \\
Too many demands other than teaching & 5 \\
Classroom management issues & 6 \\
Certification out of state too long to change it & 6 \\
Extended employment & 7 \\
Graduate school & 7 \\
Lack of community support & 7 \\
Two fifths of classes were "true" science not ag & 7 \\
Dumping ground & 7 \\
Demands of the job & 7 \\
Teaching expectations too high & 7 \\
Lack of parental support & 8 \\
High caliber students not allowed to register for ag classes & 8 \\
Student teaching experience & 8 \\
Students promoted when failing courses & 8 \\
Other faculty members & 8 \\
Students failing other courses dumped into ag classes & 7 \\
\hline
\end{tabular}

\section{Research Question Ten}

Research question ten addressed the relationship between a respondent's involvement in agricultural youth organizations (FFA and 4-H) and the decision to teach 
agriculture. The decision to teach agriculture was based on participants responses to the questions "I wanted to teach agriculture when entering college" and "I wanted to teach agriculture after student teaching." Individuals who answered strongly disagree, moderate disagree, and slightly disagree were coded as "no" for wanting to teach. Respondents who slightly agreed, moderately agreed, and strongly agreed were recoded to "yes" for wanting to teach agriculture. Agricultural youth organization involvement was considered to be the following factors: number of chapter FFA offices, number of state FFA offices, number of FFA leadership conferences, number of FFA CDE events, number of FFA activities, number of 4-H club offices, number of state 4-H offices, and number of 4-H activities.

Individuals who did not want to teach agriculture when entering college had held a mean of 1.16 chapter FFA offices $(S D=1.26)$. Those who wanted to teach agriculture had held a mean of 2.04 chapter offices $(S D=1.10)$ (see Table 53).

Respondents not wanting to teach when entering college had held a mean of .05 state FFA offices $(S D=.23)$. Those who wanted to teach when entering college held a mean of .23 state FFA offices $(S D=.43)$ (see Table 53).

Those who did not want to teach when entering college had attended a mean of 1.51 FFA leadership conferences $(S D=1.84)$. Individuals who wanted to teach agriculture when entering college had attended a mean of 3.52 FFA leadership conferences $(S D=2.30)($ see Table 53).

Individuals not wanting to teach agriculture when they entered college had competed in a mean of 4.59 career development events $(S D=4.79)$. Those who wanted to teach had competed in a mean of $5.41(S D=3.94) \mathrm{CDE}$ competitions (see Table 53). 
Those who did not want to teach when entering college had attended a mean of $2.70(S D=1.51)$ FFA activities. Those who wanted to teach when entering college had attended a mean of $3.41(S D=1.24)$ FFA activities (see Table 53).

Individuals not wanting to teach when entering college had served a mean of 2.10 4-H club offices $(S D=1.41)$. Those who wanted to teach when entering college had served a mean of $2.42(S D=1.39) 4-\mathrm{H}$ club offices (see Table 53).

Respondents who did not want to teach when entering college had served a mean of $.054-\mathrm{H}$ state offices $(S D=.22)$. Those who did want to teach had served a mean of zero state $4-\mathrm{H}$ offices $(S D=0)($ see Table 53$)$

Table 53

Agricultural Youth Organization Involvement of Participants

\begin{tabular}{lrrrr}
\hline \multirow{2}{*}{ Type of Participation } & \multicolumn{3}{c}{ Wanted to Teach When Entering College } \\
\cline { 2 - 5 } & \multicolumn{3}{c}{ No } & \multicolumn{3}{c}{ Yes } \\
\cline { 2 - 5 } & \multicolumn{1}{c}{ SD } & \multicolumn{2}{c}{ S } & \multicolumn{1}{c}{ SD } \\
\hline Number of Chapter FFA Offices & 1.16 & 1.26 & 2.04 & 1.10 \\
Number of State FFA Offices & .05 & .23 & .24 & .43 \\
Number of FFA Leadership Conferences & 1.51 & 1.84 & 3.52 & 2.30 \\
Number of FFA CDE Events & 4.59 & 4.79 & 5.41 & 3.94 \\
Number of FFA Activities & 2.70 & 1.51 & 3.41 & 1.24 \\
Number of 4-H Club Offices & 2.10 & 1.41 & 2.42 & 1.39 \\
Number of 4-H State Offices & .05 & .22 & .00 & .00 \\
Number of 4-H Activities & 4.45 & 3.39 & 4.92 & 3.27 \\
\hline
\end{tabular}

A $t$-test statistical procedure was used to determine if statistical differences existed in the means of components that defined agricultural youth organization involvement between individuals who did want to teach agriculture when entering 
college $(N=54)$ and respondents who did not want to teach when entering college $(N=$ 37). Four of the components of agricultural youth organization participation were significant at $\alpha \leq .05$.

Individuals who wanted to teach agriculture when entering college $(M=2.04, S D$ $=1.10$ ) had served more chapter FFA offices than individuals who did not want to teach when entering college $(M=1.16, S D=1.26)(t=-3.516, d f=89)($ see Table 54). The difference exhibited a medium effect (Cohen, 1988).

Respondents wanting to teach agriculture when entering college $(M=.24, S D=$ .43) had held more state FFA offices than individuals not wanting to teach when entering college $(M=.05, S D=.23)(t=-2.675, d f=84.54)($ see Table 54). The difference exhibited a large effect (Cohen, 1988).

Those who wanted to teach when entering college $(M=3.52, S D=2.30)$ had attended more leadership conferences than individuals who did not want to teach when entering college $(M=1.51, S D=1.84)(t=-4.417, d f=89)($ see Table 54). The difference of the means exhibited a small effect (Cohen, 1988).

Respondents wanting to teach when entering college $(M=3.41, S D=1.24)$ had participated in more FFA activities than individuals who did not want to teach when entering college $(M=2.70, S D=1.51)(t=-2.442, d f=89)($ see Table 54). The difference exhibited a small effect (Cohen, 1988). 
Table 54

Comparison of Means of Agricultural Youth Organization Involvement and Decision to Teach when Entering College

\begin{tabular}{|c|c|c|c|c|}
\hline \multirow[t]{3}{*}{ Type of Involvement } & \multicolumn{2}{|c|}{$\begin{array}{l}\text { Wanted to Teach } \\
\text { Agriculture When } \\
\text { Entering College }\end{array}$} & & \\
\hline & No & Yes & & \\
\hline & $M$ & $M$ & $d f$ & $t$ \\
\hline Number of FFA Chapter Offices & 1.16 & 2.04 & 89 & $-3.516^{*}$ \\
\hline Number of FFA State Offices & .05 & .24 & 84.54 & $-2.675^{*}$ \\
\hline $\begin{array}{l}\text { Number of FFA Leadership } \\
\text { Conferences }\end{array}$ & 1.51 & 3.52 & 89 & $-4.417^{*}$ \\
\hline Number of FFA Activities & 37 & 54 & 89 & $-2.442 *$ \\
\hline
\end{tabular}
$*_{\alpha} \leq .05$

Individuals who wanted to teach after student teaching had served a mean of 1.74 chapter FFA offices $(S D=1.24)$. Those who did not want to teach agriculture after student teaching had served a mean of $1.31(S D=1.18)$ chapter FFA offices (see Table $55)$.

Respondents wanting to teach after student teaching had served a mean of .15 state FFA offices $(S D=.36)$. People who did not want to teach agriculture after student teaching had served a mean of .23 state FFA offices $(S D=.44)$ (see Table 55).

Those who wanted to teach agriculture after student teaching had attended a mean of $2.69(S D=2.26)$ FFA leadership conferences. Those who did not wish to teach after student teaching had participated in a mean of $2.77(S D=2.83)$ FFA leadership conferences (see Table 55). 
Individuals wanting to teach after student teaching had competed in a mean of $5.14(S D=4.21)$ FFA career development events. Respondents not wanting to teach after student teaching had competed in a mean of $4.69(S D=4.99)$ CDEs (see Table 55).

Those who wanted to teach after student teaching had participated in a mean of $3.18(S D=1.31)$ FFA activities. Individuals who did not want to teach after student teaching had participated in a mean of $2.77(S D=1.83)$ FFA activities (see Table 55).

Respondents wanting to teach after student teaching had served a mean of 2.44 $(S D=1.32) 4-\mathrm{H}$ club offices. Those who did not want to teach agriculture after student teaching had served a mean of $1.70(S D=1.57) 4-\mathrm{H}$ club offices (see Table 55$)$.

People who wanted to teach after student teaching had served a mean of $.03(S D=$ .17) 4-H state offices. Those who did not want to teach agriculture after student teaching had served a mean of zero $(S D=0)$ state 4-H offices (see Table 55).

Individuals who wanted to teach agriculture after student teaching had participated in a mean of $4.89(S D=3.13) 4-\mathrm{H}$ activities. Those who did not want to teach agriculture after student teaching had participated in a mean of $4.10(S D=3.96) 4$ $\mathrm{H}$ activities (see Table 55).

A $t$-test statistical procedure was used to determine if statistical differences existed in the means of components that defined agricultural youth organization involvement between individuals who wanted to teach agriculture after student teaching and respondents who did not want to teach after completing the student teaching experience. None of the means were statistically different $(\alpha \leq .05)$. 
Table 55

Means of Agricultural Youth Involvement and Decision to Teach After Student Teaching

\begin{tabular}{lrrrr}
\hline \multirow{2}{*}{ Type of Involvement } & \multicolumn{3}{c}{ Wanted to Teach After Student Teaching } \\
\cline { 2 - 5 } & \multicolumn{3}{c}{ No } & \multicolumn{3}{c}{ Yes } \\
\cline { 2 - 5 } & $M$ & $S D$ & $M$ & $S D$ \\
\hline Number of Chapter FFA Offices & 1.31 & 1.18 & 1.74 & 1.24 \\
Number of State FFA Offices & .23 & .44 & .15 & .36 \\
Number of FFA Leadership Conferences & 2.77 & 2.83 & 2.69 & 2.26 \\
Number of FFA CDE Events & 4.69 & 4.99 & 5.14 & 4.21 \\
Number of FFA Activities & 2.77 & 1.83 & 3.18 & 1.31 \\
Number of 4-H Offices & 1.70 & 1.57 & 2.44 & 1.32 \\
Number of 4-H State Offices & .00 & .00 & .03 & .17 \\
Number of 4-H Activities & 4.10 & 3.96 & 4.89 & 3.13 \\
\hline
\end{tabular}

Research Question Eleven

Research question eleven involved determining what components of an individual's background had the most impact on their decision to teach agriculture.

The decision to teach was considered at three stages: wanting to teach when entering college, wanting to teach after student teaching, and currently teaching. Discriminant analysis was used to determine which variables had an impact on an individual's decision regarding teaching agriculture.

Decision to Teach Before Entering College

A stepwise discriminant analysis was conducted on the data to determine what variables influenced an individual to want to teach when entering college. The null hypothesis tested was there would be no impact by variables on the group centroids on the discriminant scores. At an alpha level of $\leq .05$, the null hypothesis was rejected and 
the alternate hypothesis was accepted that variables did have an impact on the decision to teach when entering college (see Table 56).

Table 56

Discriminant Analysis of Decision to Teach when Entering College

\section{$\underline{\text { Discriminant Function }}$}

\begin{tabular}{|c|c|c|c|c|}
\hline$\frac{\text { Variable }}{\text { Number of FFA }}$ & $\underline{\mathrm{a}}$ & $\underline{\mathrm{s}}^{\mathrm{b}}$ & \multicolumn{2}{|c|}{ Centroids } \\
\hline $\begin{array}{l}\text { Leadership } \\
\text { Conferences }\end{array}$ & .747 & .706 & $\begin{array}{l}\text { Wanted to } \\
\text { Teach }\end{array}$ & .409 \\
\hline $\begin{array}{l}\text { Classroom and } \\
\text { Laboratory }\end{array}$ & .710 & .666 & $\begin{array}{l}\text { Did not want } \\
\text { to Teach }\end{array}$ & -.671 \\
\hline
\end{tabular}

\begin{tabular}{ll} 
Eigenvalue $\quad \underline{\mathrm{Rc}}^{\mathrm{c}} \quad$ Wilks' Lambda \\
\hline
\end{tabular}

$.290 .474 \quad .775^{*}$

$\underline{\mathrm{a}}$ - standardized canonical discriminant function coefficients, ${ }^{\mathrm{b}}-$ structure coefficients, $^{\mathrm{c}}$ -canonical correlation coefficient, $* \alpha \leq .05$

The standardized canonical discriminant function coefficients for the variables number of FFA leadership conferences and classroom and laboratory were .747 and .710 respectively. The structure coefficients were .706 for the number of FFA leadership conferences and .666 for classroom and laboratory. A Wilks' Lambda value of .775 indicated that $77.5 \%$ of the variance was unexplained. The discriminant function accounted for $23.5 \%(\mathrm{Rc}=.474)$ of the variance that could be explained. An eigenvalue of .290 indicated that the dicriminant function can explain only .290 times as much as that which was not explained. The centroids for wanted to teach when entering college and did not want to teach when entering college were .409 and -.671 respectively (see Table 56). Of the original grouped cases, $69.2 \%$ were correctly classified. 


\section{Decision to Teach after Student Teaching}

A stepwise discriminant analysis was conducted on the data to determine what variables influenced an individual to want to teach after student teaching. The null hypothesis tested was there would be no impact by variables between the group centroids on the discriminant scores. At an alpha level of $\leq .05$, the null hypothesis was rejected and the alternate hypothesis was accepted that variables did have an impact on the decision to teach after student teaching (see Table 57).

Table 57

Disciminant Analysis of Decision to Teach after Student Teaching

\section{Discriminant Function}

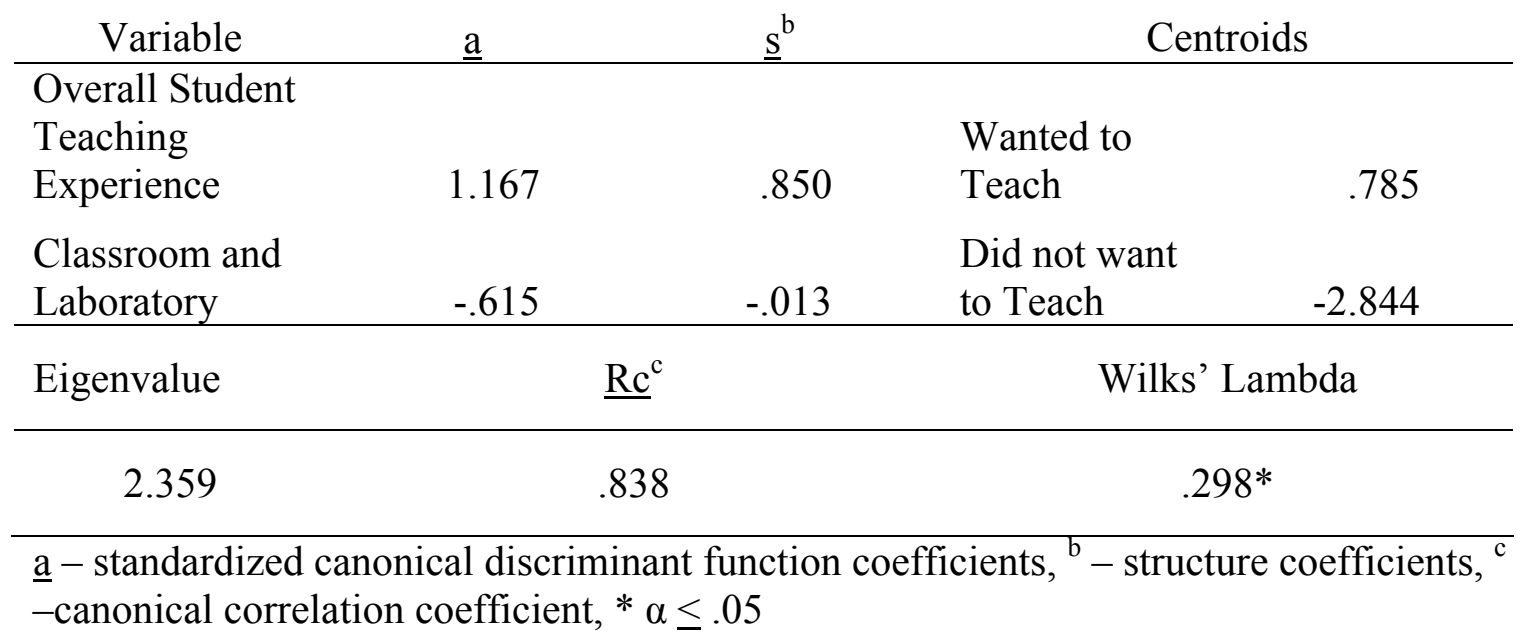

The standardized canonical discriminant function coefficients for the variables overall student teaching experience and classroom and laboratory were 1.167 and -.615 respectively. The structure coefficients were .850 for the overall student teaching experience and -.013 for classroom and laboratory. A Wilks' Lambda value of .298 indicated that $29.8 \%$ of the variance was unexplained. The discriminant function accounted for $71.2 \%(\mathrm{Rc}=.838)$ of the variance that could be explained. An eigenvalue 
of 2.359 indicated that the dicriminant function can explain 2.359 times as much as that which was not explained. The centroids for wanted to teach when entering college and did not want to teach when entering college were .785 and -2.844 respectively (see Table 57). Of the original grouped cases, $87.9 \%$ were correctly classified.

\section{Decision to Teach}

A stepwise discriminant analysis was conducted on the data to determine what variables influenced an individual to teach. The null hypothesis tested was there would be no impact by variables between the group centroids on the discriminant scores. At an alpha level of $\leq .05$, the null hypothesis was rejected and the alternate hypothesis was accepted that variables did have an impact on the decision to teach (see Table 58).

Table 58

Discriminant Analysis of Decision to Teach

\section{Discriminant Function}

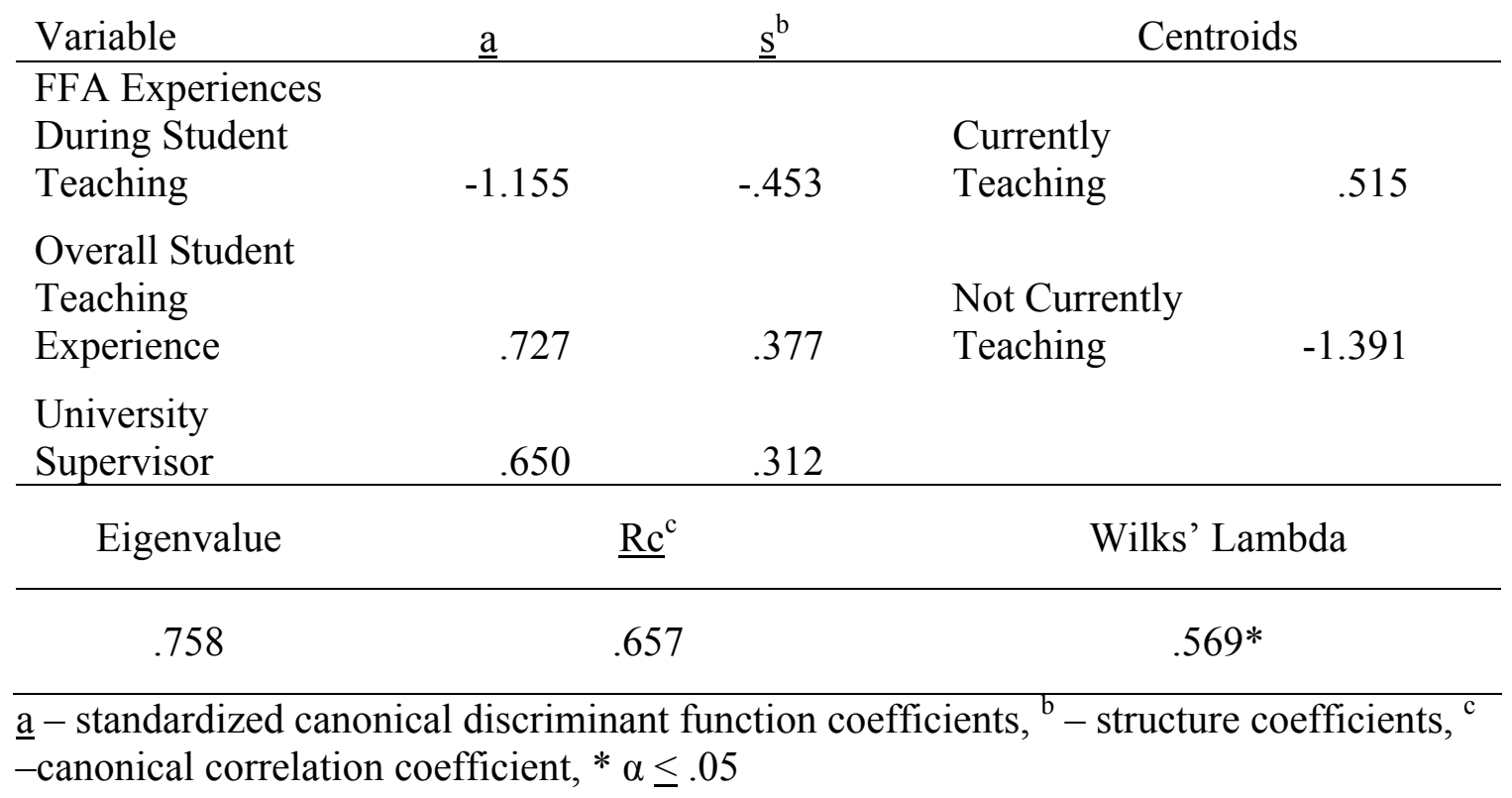


The standardized canonical discriminant function coefficients for the variables FFA experiences during student teaching, overall student teaching experience, and university supervisor were $-1.155, .727$ and .650 respectively. The structure coefficients were -.453 for FFA experiences during student teaching, .377 for the overall student teaching experience, and .312 for university supervisor. A Wilks' Lambda value of .569 indicated that $56.9 \%$ of the variance was unexplained. The discriminant function accounted for $44.1 \%(\mathrm{Rc}=.657)$ of the variance that could be explained. An eigenvalue of .758 indicated that the discriminant function can explain .758 times as much as that which was not explained. The centroids for currently teaching and not currently teaching were .515 and -1.391 respectively (see Table 58 ). Of the original grouped cases, $70.9 \%$ were correctly classified. 


\section{CHAPTER V}

\section{Summary, Conclusions, and Recommendations}

\section{Purpose of the Study}

The purpose of this study was to determine the factors that influence an individual's decision to teach agricultural education. This study was designed to explore these factors in order to provide universities, teacher educators, and agricultural educators with information to aid the recruitment and retention of individuals who will enter a teaching profession in agricultural education.

\section{Objectives of the Study}

The objectives of the study are reflected in the following research questions:

1. What were the student teaching site selection processes, cooperating teacher characteristics, and university supervisor characteristics associated with individuals who were not satisfied with the student teaching experience?

2. What were the student teaching site selection processes, cooperating teacher characteristics, and university supervisor characteristics associated with individuals who were satisfied with the student teaching experience?

3. What did participants identify as factors that influenced their decision to teach agriculture?

4. What was the level of participation in the FFA for those who cited "FFA involvement" as a factor influencing their decision to teach agriculture?

5. What was the level of participation in 4-H for those who cited "4-H involvement" as a factor influencing their decision to teach agriculture? 
6. For those who did not enter the agricultural teaching profession, what reason(s) did respondents identify for not teaching agriculture?

7. When did the participants who never taught agriculture decide not to teach?

8. What were the occupations of those who did not teach agriculture?

9. What were the factors that influenced an individual to leave the agricultural teaching field?

10. What was the relationship between a respondent's involvement in agricultural youth organizations (FFA and 4-H) and the decision to teach agriculture?

11. What components of an individual's background had the most impact on their decision to teach agriculture?

\section{Summary}

The accessible population for the study included 217 individuals who had student taught between 2002-2005 while attending Clemson University, North Carolina State University, The Pennsylvania State University, Virginia Polytechnic Institute and State University, and West Virginia University. Most of the respondents included females between the age of 23-25 who were currently teaching agriculture.

\section{Research Question One and Two}

Individuals who were satisfied with their student teaching experience were more likely to request a student teaching site based on their strengths. In addition, satisfied individuals were more satisfied with their student teaching placement site. Respondents who were satisfied with student teaching rated all characteristics of their cooperating teacher higher than the individuals who were not satisfied with student teaching. Also, people who had a positive student teaching experience received more constructive 
feedback from their university supervisor compared to individuals not satisfied with student teaching. Individuals satisfied with their student teaching experience had a more positive relationship with their university supervisor than individuals who were not satisfied with student teaching.

Research Question Three

The top influence on an individual's decision to teach agriculture was their agriculture teacher. The second, third, fourth, and fifth most influential factors on the decision to teach agriculture were as follows: an individual's agricultural background, FFA involvement, high school agriculture program involvement, and family.

\section{Research Question Four}

Individuals who cited "FFA involvement" as an influence on their decision to teach had served in more chapter offices than those who did not list "FFA involvement" as an influence on teaching. Respondents who were influenced by their FFA involvement had attended more leadership conferences and participated in more FFA activities compared to individuals who were not influenced by their FFA involvement.

\section{Research Question Five}

Respondents whose 4-H involvement had an influence on their decision to teach agriculture had held more 4- $\mathrm{H}$ club offices than individuals who were not influenced by their 4-H involvement. People who cited "4-H involvement" as an influence to teach had participated in more 4-H activities than individuals who did not cite "4-H involvement." 


\section{Research Question Six}

Individuals who had never taught agriculture did not teach mostly because of their student teaching experience. The remaining top four reasons included demands of the job, low salary, no teaching jobs in the area, and time requirements.

\section{Research Question Seven}

Of the respondents who never taught, 11 individuals wanted to teach when they entered college. Eighteen of the individuals wanted to teach before enrolling in teaching methods, 20 individuals wanted to teach before student teaching, and 12 people still wanted to teach after they had completed their student teaching experience.

\section{Research Question Eight}

Individuals who were not currently teaching were employed in a wide variety of jobs. The most common occupations included Extension, NRCS, agricultural business, graduate student, and some individuals were both an agricultural teacher and a graduate student.

\section{Research Question Nine}

The six individuals who had left teaching identified factors that influenced that decision. The most common reason people left teaching was a lack of administrative support. The remaining top five reasons included: low salary, time requirements, no other available jobs in area, unsuccessful as a teacher and too many demands other than teaching.

Research Question Ten

Four components of agricultural youth organization involvement had an impact on the respondents' decisions to teach when entering college. Individuals who wanted to 
teach when entering college had held more state and chapter FFA offices, had attended more FFA leadership conferences, and participated in more FFA activities. Agricultural youth organization involvement had no significant impact on the teaching decisions of the respondents after the completion of the student teaching experience.

\section{Research Question Eleven}

The respondents' teaching decisions when entering college were impacted by their classroom and laboratory experiences and the number of FFA leadership conferences they had attended. The teaching decision after student teaching was based on the overall student teaching experience and the classroom and laboratory experiences during student teaching. The final decision about teaching agriculture, actually seeking and becoming employed, was influenced mostly by the FFA experiences during student teaching, overall student teaching experience, and the university supervisor.

\section{Conclusions}

Based on the results of this study, the following conclusions were made:

1. The satisfaction or dissatisfaction of an individual's student teaching experience was determined mostly by the characteristics of the cooperating teacher, compared to the site selection process and university supervisor variables.

2. Agricultural teachers are the best spokesperson for the recruitment of individuals into the agricultural education profession.

3. An individual's FFA involvement has a greater influence on their decision to teach if they were active with chapter activities, attended leadership conferences, and served as a chapter FFA officer. 
4. An individual's 4-H involvement has a greater influence on their decision to teach if they were active with 4-H activities and served as a 4-H club officer.

5. Past FFA members are more likely to want to teach agriculture when they enter college if they were actively involved with chapter FFA activities, attended FFA leadership conferences, and served as a chapter and/or state FFA officer.

6. Problems or dissatisfaction with the student teaching experience can cause an individual to decide not to teach agriculture.

7. The critical points at which individuals make their decision about teaching agriculture occur when they enter college and after the student teaching experience.

8. Individuals who are not currently teaching agriculture seek employment with the Extension Service, NRCS, and agricultural businesses and gain entrance into graduate school.

9. The lack of administrative support, low salary, lack of other jobs in the area, unsuccessfulness as a teacher, time requirements, and demands of teaching agriculture are common problems that lead to the loss of agricultural teachers.

10. The number of FFA leadership conferences an individual attends is a predictor of an individual's decision to teach when entering college.

11. An individual's classroom and laboratory experiences during student teaching and their overall student teaching experience can be used to predict an individual's decision to teach after student teaching. 
12. The FFA experiences during student teaching, overall student teaching experience, and university supervisor characteristics determine an individual's final decision to be employed as an agricultural teacher.

\section{Recommendations}

The researcher makes the following recommendations based on the results of the research:

1. Agricultural teachers should be made aware that they have a major impact on the supply of future agricultural teachers.

2. Universities should provide additional teacher training opportunities for individuals to gain more experience and a better understanding about a career in teaching agriculture before individuals enroll in teaching methods. These opportunities could include helping coordinate or judge Career Development Events or accompanying FFA chapters while attending conventions and leadership conferences.

3. Universities should conduct a training course for individuals planning to serve as cooperative teachers to prepare them for their responsibilities during student teaching.

4. Student teaching site placements should be largely based on the characteristics of the cooperating teacher, based on the cooperating teacher characteristics addressed by this study.

5. Students planning to student teach should be required to meet with their cooperating teacher and be made aware of student teaching expectations prior to the beginning of their student teaching experience. 
6. An inventory of agricultural programs within each respective state should be created to help individuals make more informed decisions regarding the selection of their student teaching site. This inventory should include information such as classroom and laboratory activities, FFA activities, and SAEs that are associated with specific agricultural programs.

7. Research should be expanded to include past student teachers from other universities in the United States responsible for agricultural teacher training.

8. Further research should be conducted to address other factors that could affect an individual's decision to teach agricultural education.

9. A study should be designed to determine what influences individuals who did not have a membership in the National FFA Organization or 4-H organization to decide to teach agricultural education.

10. A longitudinal study should be conducted to determine if a trend exists for reasons an individual decides to teach agriculture. 


\section{REFERENCES}

Ary, D., Jacobs, L.C., Razavieh, A., \& Sorenson, C. (2006). Introduction to research in education $\left(7^{\text {th }}\right.$ ed.). California: Thomson Wadsworth.

Bandura, A. (1986). Social foundations of thought and action: A social cognitive theory. Englewood Cliffs, NJ: Prentice Hall.

Berryhill, S. (2005). WVU: Student Teacher Handbook.

Boone, H. N., Jr. (2006, July/August). Where are they now? West Virginia AG ED NEWS and VIEWS, LVI(3), 1.

Cohen, J. (1988). Statistical power analysis for the behavioral sciences ( $2^{\text {nd }}$ ed.). Hillsdale, NJ: Lawrence Erlbaum Associates.

Cotton, W. A. (2005). Teacher recruitment by secondary agricultural educators. Unpublished master's thesis, Montana State University, Bozeman. [Electronic Version]. Retrieved April 21, 2007 from http://www.montana.edu/etd/available/ unrestricted/Cotton_0805.pdf

Dillman, D. A. (2000). Mail and internet surveys: The tailored design method ( $7^{\text {th }}$ ed.). New York: John Wiley \& Sons, Inc.

Edwards, M. C., \& Briers, G. E. (2000). Cooperating teachers' perceptions of important elements of the student teaching experience: A focus group approach with qualitative follow-up. Proceedings of the $27^{\text {th }}$ Annual National Agricultural Education Research Conference. Retrieved September 9, 2006, from http://aaaeonline.ifas.ufl.edu/NAERC/2000/web/k2.pdf

Gray, M. \& Daugherty, M. (2004). Factors that influence students to enroll in technology education program. [Electronic Version]. Journal of Technology Education, 15(2). Retrieved June 20, 2007, from http://scholar.lib.vt.edu/ejournals/ JTE/v15n2/gray.html

Harlin, J. F., Edwards, M. C., \& Briers, G. E. (2002). A comparison of student teachers' perceptions of important elements of the student teaching experience before and after an 11-week field experience. [Electronic version]. Journal of Agricultural Education, 43(3), 72-83. Retrieved September 9, 2006, from http://pubs.aged.tamu.edu/jae/pdf/Vol43/43-03-72.pdf

Harms, B. M. \& Knobloch, N. A. (2005). Preservice Teachers' Motivation and Leadership Behaviors Related to Career Choice. [Electronic Version] Career and Technical Education Research, 30(2), 101-124. Retrieved April 21, 2007, from http://scholar.lib.vt.edu/ejournals/CTER/v30n2/pdf/harms.pdf 
Hovatter, G. A. (2002). Impact of student teaching experiences, personal demographics, and selected factors on the decisions of pre-service agricultural education teachers to enter into teaching. (Master's Thesis, West Virginia University, 2002).

Kasperbauer, H. J. \& Roberts, T. G. (2007). Influence of the relationship between the student teacher and cooperating teacher on student teacher's decision to enter teaching. Journal of Agricultural Education, 48(1), 8-19.

Martin, R. A. \& Yoder, E.P. (1985). Clinical teaching analysis: A procedure for supervising teachers. The Journal of the American Association of Teacher Educators in Agriculture, 26(4), 16-21, 33.

Morrish, D. G., Harlin, J. F., Briers, G. E., Shinn, G. C., \& Hoyle, J.R. (2003). Relationships of important elements of the student teaching experience and methods of student teaching placement to the quality of experience of student teachers. Unpublished doctoral dissertation, Texas A\&M University, College Station. [Electronic version]. Retrieved September 15, 2006, from https://txspace.tamu.edu/bitstream/1969.1/476/1/etd-tamu-2003B-2003063011Morr-1.pdf

National 4-H Headquarters. (n.d., A). Understanding 4-H: Purpose, History and Structure. In 4-H 101 Handbook. Retrieved June 19, 2007, from http://www.national4-hheadquarters.gov/library/4H101-I_Understanding_4H.pdf

National 4-H Headquarters. (n.d., B). Developing Life Skills Through 4-H Clubs. In 4-H 101 Handbook. Retrieved June 19, 2007, from http://www.national4hheadquarters.gov/library/4H101-II_lifeskills.pdf

National FFA Organization. (n.d., A). Career Development Events. Retrieved June 19, 2007, from http://www.ffa.org/index.cfm?method=c_programs.CDE

National FFA Organization. (n.d., B). SAE: Supervised Agricultural Experience. Retrieved June 19, 2007, from http://www.ffa.org/index.cfm?method= c_programs.SAE

National FFA Organization. (n.d., C). The FFA Mission. Retrieved June 19, 2007, from http://www.ffa.org/index.cfm?method=c_about.mission

Norris, R. J., Larke, A. Jr., \& Briers, G. E. (1990). Selection of student teaching centers and cooperating teachers in agriculture and expectations of teacher educators regarding these components of a teacher education program: A national study. [Electronic version]. Journal of Agricultural Education, 31(1), 58-63. Retrieved September 1, 2006, from http://pubs.aged.tamu.edu/jae/pdf/Vol31/31-01-58.pdf 
Radhakrishna, R. B. (2005). Influence of 4-H program on former 4-H members' career and life experiences. [Electronic Version]. Proceedings of the 2005 National AAAE Research Conference. Retrieved June 21, 2007, from http://aaae.okstate.edu/proceedings/2005/Articles/077.pdf reportaged.pdf

Robinson, J. P. Shaver, P. R., \& Wrightsman, L. S. (1991). Criteria for scale selection and evaluation. In J. P. Robinson, P. R. Shaver, \& L. S. Wrightsman (Eds.). Measures of personality and social psychological attitudes (pp. 1-16) New York: Academic Press.

Rocca, S. J. \& Washburn, S. G. (2006). Predicting preservice agriculture teachers intentions to teach. [Electronic Version]. Proceedings of the 2006 National AAAE Research Conference. Retrieved November 14, 2006 from, http://aaae.okstate.edu/proceedings/2006/Research\%20Papers/Paper\%20D-1.pdf

Rome, C. \& Moss, J. W. (1990). Satisfaction with agricultural education student teaching. [Electronic version]. Journal of Agricultural Education, 31(2), 29-34. Retrieved September 15, 2006 from http://pubs.aged.tamu.edu/jae/pdf/Vol31/3102-29.pdf

Schutz, P.A., Crowder, K. C., \& White, V. E. (2001). The development of a goal to become a teacher. [Electronic Version]. Journal of Educational Psychology 93(2), 299-308. Retrieved April 21, 2007, from http://content.ebscohost.com.www. libproxy.wvu.edu/pdf18_21/pdf/ddd/pdh/edu/edu-93-2-299.pdf

Team Ag Ed. (n.d.). Unmistakable potential: 2005-2006 Annual Report on Agricultural Education. Retrieved May 11, 2007, from http://aaae.okstate.edu/files/07.annual

Wildman, M. \& Torres, R. M. (2001). Factors identified when selecting a major in agriculture. [Electronic Version], Journal of Agricultural Education, 42(2), 4655. Retrieved April 21, 2007, from http://pubs.aged.tamu.edu/jae/pdf/Vol42/4202-46.pdf

Willems, A. L., Tollakson, J. A., Milburn, J. L., Connor, D. J., \& Hull, L. (1986). What are the key guidelines that ensure a quality student teaching experience? [Electronic Version]. Education, 107(2), 192-197. Retrieved November 14, 2006, from http://web.ebscohost.com/ehost/delivery?vid=81\&hid=117\&sid=603d5decde8b-4794-a9 
APPENDIX A:

Questionnaire 


\title{
Factors that Influence an Individual's Decision to Teach Agricultural Education
}

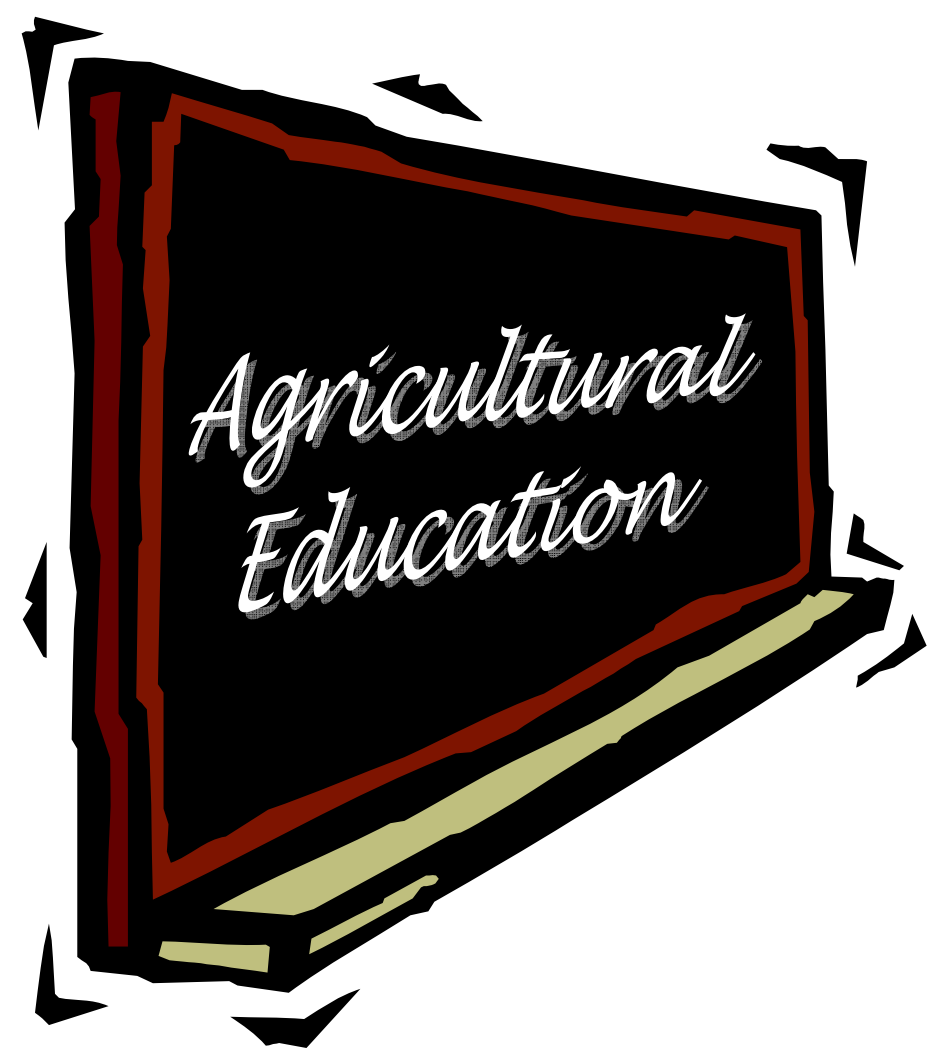

Lee Ann "Annie" Hall

\author{
Graduate Student
}

Agricultural and Extension Education

Davis College of Agriculture, Forestry, and Consumer Sciences

West Virginia University

Morgantown, WV 26506 


\section{Factors Influencing an Individual's Decision to Teach Agricultural Education}

Instructions: Using the following Likert scale, rate your opinion on each of the components of your student teaching experience. Indicate your opinion by circling the letters that best corresponds to your response: SD- Strongly Disagree, MD- Moderately Disagree, SD- Slightly Disagree, SA- Slightly Agree, MA- Moderately Agree, and SAStrongly Agree.

\begin{tabular}{|c|c|c|c|c|c|c|}
\hline ISSUE & 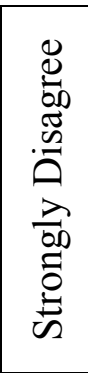 & 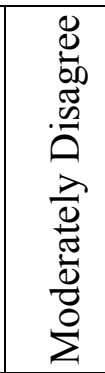 & 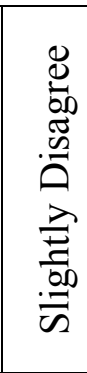 & 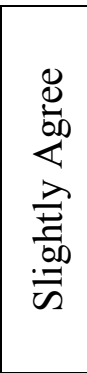 & 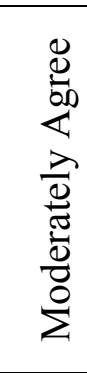 & 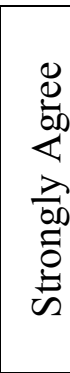 \\
\hline \multicolumn{7}{|l|}{ Site Selection } \\
\hline $\begin{array}{l}\text { 1. The selection of my student teaching site was } \\
\text { solely my decision. }\end{array}$ & SD & MD & SD & SA & MA & SA \\
\hline $\begin{array}{l}\text { 2. I had little input into the selection of my student } \\
\text { teaching site. }\end{array}$ & SD & MD & SD & SA & MA & SA \\
\hline $\begin{array}{l}\text { 3. University faculty influenced my student } \\
\text { teaching site selection. }\end{array}$ & SD & MD & SD & SA & MA & SA \\
\hline $\begin{array}{l}\text { 4. Other people in the agricultural education } \\
\text { profession influenced my student teaching site } \\
\text { selection. }\end{array}$ & SD & MD & SD & SA & MA & SA \\
\hline $\begin{array}{l}\text { 5. My student teaching placement site was my first } \\
\text { choice. }\end{array}$ & SD & MD & SD & SA & MA & SA \\
\hline $\begin{array}{l}\text { 6. I requested a student teaching site to match my } \\
\text { strengths. }\end{array}$ & SD & MD & SD & SA & MA & SA \\
\hline $\begin{array}{l}\text { 7. I requested a student teaching site to improve } \\
\text { my weaknesses. }\end{array}$ & SD & MD & SD & SA & MA & SA \\
\hline $\begin{array}{l}\text { 8. I requested a student teaching site based on the } \\
\text { agriculture teacher there. }\end{array}$ & SD & MD & SD & SA & MA & SA \\
\hline $\begin{array}{l}\text { 9. I requested a student teaching site based on the } \\
\text { facilities. }\end{array}$ & SD & MD & SD & SA & MA & SA \\
\hline
\end{tabular}




\begin{tabular}{|c|c|c|c|c|c|c|}
\hline ISSUE & 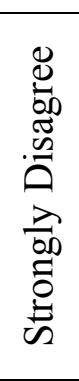 & 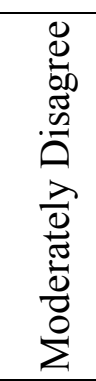 & 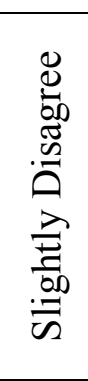 & 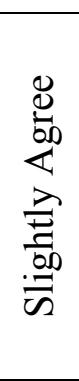 & 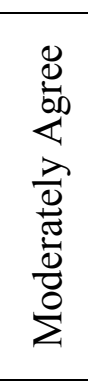 & 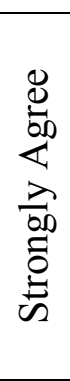 \\
\hline $\begin{array}{l}\text { 10. I requested a student teaching site based on the } \\
\text { location of the school. }\end{array}$ & SD & MD & SD & SA & MA & SA \\
\hline $\begin{array}{l}\text { 11. I was not satisfied with my student teaching } \\
\text { placement site. }\end{array}$ & SD & MD & SD & SA & MA & SA \\
\hline \multicolumn{7}{|l|}{ Cooperating Teacher } \\
\hline $\begin{array}{l}\text { 12. My cooperating teacher introduced my } \\
\text { credentials to help establish my rapport with the } \\
\text { students. }\end{array}$ & SD & MD & SD & SA & MA & SA \\
\hline $\begin{array}{l}\text { 13. My cooperating teacher was readily available to } \\
\text { answer my questions. }\end{array}$ & SD & MD & SD & SA & MA & SA \\
\hline $\begin{array}{l}\text { 14. My cooperating teacher supported my decisions } \\
\text { in front of students. }\end{array}$ & SD & MD & SD & SA & MA & SA \\
\hline $\begin{array}{l}\text { 15. My cooperating teacher was willing to help me } \\
\text { in any way possible. }\end{array}$ & SD & MD & SD & SA & MA & SA \\
\hline $\begin{array}{l}\text { 16. My cooperating teacher could have provided me } \\
\text { with more guidance. }\end{array}$ & SD & MD & SD & SA & MA & SA \\
\hline $\begin{array}{l}\text { 17. My cooperating teacher evaluated my } \\
\text { performance each week. }\end{array}$ & SD & MD & SD & SA & MA & SA \\
\hline $\begin{array}{l}\text { 18. My cooperating teacher encouraged me to go } \\
\text { with him/her and students to FFA events and } \\
\text { activities. }\end{array}$ & SD & MD & SD & SA & MA & SA \\
\hline $\begin{array}{l}\text { 19. My cooperating teacher provided feedback } \\
\text { about my progress during student teaching. }\end{array}$ & SD & MD & SD & SA & MA & SA \\
\hline $\begin{array}{l}\text { 20. My cooperating teacher had a positive attitude } \\
\text { toward teaching. }\end{array}$ & SD & MD & SD & SA & MA & SA \\
\hline $\begin{array}{l}\text { 21. My cooperating teacher had a positive attitude } \\
\text { toward students. }\end{array}$ & SD & MD & SD & SA & MA & SA \\
\hline $\begin{array}{l}\text { 22. My cooperating teacher had a positive attitude } \\
\text { toward the agricultural education profession. }\end{array}$ & SD & MD & SD & SA & MA & SA \\
\hline
\end{tabular}




\begin{tabular}{|c|c|c|c|c|c|c|}
\hline ISSUE & 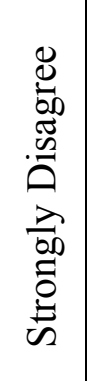 & 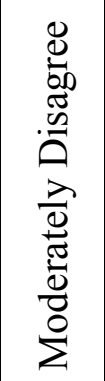 & 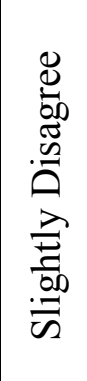 & 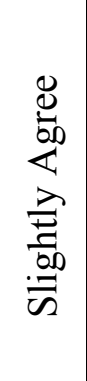 & 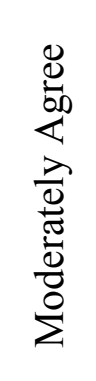 & 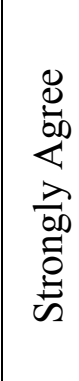 \\
\hline $\begin{array}{l}\text { 23. My cooperating teacher created a good working } \\
\text { atmosphere. }\end{array}$ & SD & MD & SD & SA & MA & SA \\
\hline $\begin{array}{l}\text { 24. I was permitted to miss school to travel with my } \\
\text { cooperating teacher to professional meetings. }\end{array}$ & SD & MD & SD & SA & MA & SA \\
\hline $\begin{array}{l}\text { 25. My cooperating teacher did not give me } \\
\text { guidance regarding SAE visits. }\end{array}$ & SD & MD & SD & SA & MA & SA \\
\hline $\begin{array}{l}\text { 26. I had a positive relationship with my } \\
\text { cooperating teacher. }\end{array}$ & SD & MD & SD & SA & MA & SA \\
\hline $\begin{array}{l}\text { 27. My cooperating teacher helped me with } \\
\text { discipline issues. }\end{array}$ & SD & MD & SD & SA & MA & SA \\
\hline $\begin{array}{l}\text { 28. My cooperating teacher and university } \\
\text { supervisor discussed my progress. }\end{array}$ & SD & MD & SD & SA & MA & SA \\
\hline \multicolumn{7}{|l|}{ University Supervisor } \\
\hline $\begin{array}{l}\text { 29. My university supervisor provided constructive } \\
\text { feedback. }\end{array}$ & SD & MD & SD & SA & MA & SA \\
\hline $\begin{array}{l}\text { 30. My university supervisor provided positive } \\
\text { feedback. }\end{array}$ & $\mathrm{SD}$ & MD & SD & SA & MA & SA \\
\hline $\begin{array}{l}\text { 31. My university supervisor offered suggestions } \\
\text { for improving my teaching techniques. }\end{array}$ & SD & MD & SD & SA & MA & SA \\
\hline $\begin{array}{l}\text { 32. My university supervisor created a positive } \\
\text { atmosphere during his/her visits. }\end{array}$ & SD & MD & SD & SA & MA & SA \\
\hline $\begin{array}{l}\text { 33. I did not have a positive relationship with my } \\
\text { university supervisor. }\end{array}$ & SD & MD & SD & SA & MA & SA \\
\hline $\begin{array}{l}\text { 34. My university supervisor made me aware he/she } \\
\text { was available in any way to help me have a } \\
\text { good student teaching experience. }\end{array}$ & $\mathrm{SD}$ & MD & SD & SA & MA & SA \\
\hline \multicolumn{7}{|l|}{ School/Community Support } \\
\hline $\begin{array}{l}\text { 35. The school administration was supportive of my } \\
\text { presence. }\end{array}$ & $\mathrm{SD}$ & MD & SD & SA & MA & SA \\
\hline $\begin{array}{l}\text { 36. The community supported me during my } \\
\text { student teaching experience. }\end{array}$ & $\mathrm{SD}$ & MD & SD & SA & MA & SA \\
\hline \multicolumn{7}{|l|}{ Classroom/Laboratory } \\
\hline 37. I did not have major discipline problems. & SD & MD & SD & SA & MA & SA \\
\hline
\end{tabular}




\begin{tabular}{|c|c|c|c|c|c|c|}
\hline ISSUE & 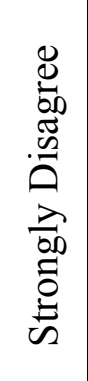 & 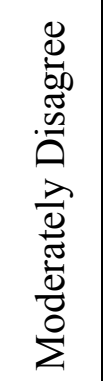 & 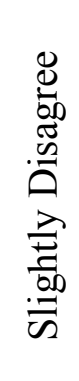 & 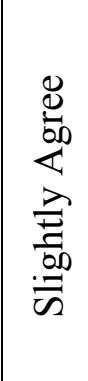 & 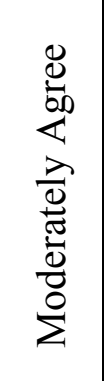 & 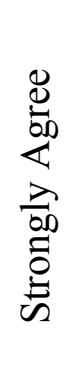 \\
\hline 38. I was able to handle discipline issues. & SD & MD & SD & SA & MA & SA \\
\hline 39. I maintained adequate classroom control. & SD & MD & SD & SA & MA & SA \\
\hline $\begin{array}{l}\text { 40. I did not feel confident in my ability to teach in a } \\
\text { laboratory setting. }\end{array}$ & SD & MD & SD & SA & MA & SA \\
\hline $\begin{array}{l}\text { 41. Students appeared to respond to my teaching } \\
\text { methods. }\end{array}$ & SD & MD & SD & SA & MA & SA \\
\hline \multicolumn{7}{|l|}{ FFA } \\
\hline $\begin{array}{l}\text { 42. I frequently helped with FFA activities outside } \\
\text { of school hours. }\end{array}$ & SD & MD & SD & SA & MA & SA \\
\hline 43. I never trained teams for FFA contests. & SD & MD & SD & SA & MA & SA \\
\hline \multicolumn{7}{|l|}{ Overall Student Teaching Experience } \\
\hline $\begin{array}{l}\text { 44. I was satisfied with my student teaching } \\
\text { experience. }\end{array}$ & SD & MD & SD & SA & MA & SA \\
\hline $\begin{array}{l}\text { 45. My student teaching experience reinforced my } \\
\text { decision to become a teacher. }\end{array}$ & SD & MD & SD & SA & MA & SA \\
\hline $\begin{array}{l}\text { 46. My student teaching experience discouraged me } \\
\text { from becoming a teacher. }\end{array}$ & SD & MD & SD & SA & MA & SA \\
\hline \multicolumn{7}{|l|}{ Decision to Teach Agriculture } \\
\hline $\begin{array}{l}\text { 47. I wanted to teach agriculture when I started } \\
\text { college. }\end{array}$ & SD & MD & SD & SA & MA & SA \\
\hline $\begin{array}{l}\text { 48. I wanted to teach agriculture before I enrolled in } \\
\text { teaching methods. }\end{array}$ & SD & MD & SD & SA & MA & SA \\
\hline $\begin{array}{l}\text { 49. I wanted to teach agriculture before my student } \\
\text { teaching experience. }\end{array}$ & SD & MD & SD & SA & MA & SA \\
\hline $\begin{array}{l}\text { 50. I did not want to teach agriculture after my } \\
\text { student teaching experience. }\end{array}$ & SD & MD & SD & SA & MA & SA \\
\hline
\end{tabular}


Instructions: Please check the appropriate response to each of the following questions.

51. How many times did your University Supervisor observe you during your student teaching experience?
a. 1-2 times
b. 3-4 times
c. 5-6 times
d. 7 or more times

52. How many Supervised Agricultural Experience (SAE) visits did you complete during your student teaching experience?
a. $0-5$
b. $6-10$
c. $11-15$
d. $16-20$
e. $21-25$
f. more than 25

53. Where you a member of the National FFA Organization? If yes, continue to question \# 54

b. No If no, skip to question \# 65

54. Please indicate all levels of FFA membership reached. (check all the apply) a. Middle School

b. High school

c. I maintained my active membership beyond high school.

d. Collegiate

e. Alumni

55. How many years were you an active FFA member?
a. $1-2$
b. $3-4$
c. $5-6$
d. $7-8$
e. $9-10$ 
56. What was the highest degree you earned in the FFA organization?
a. Discovery
b. Greenhand
c. Chapter
d. State
e. American

57. What best describes your Supervised Agricultural Experience (SAE) program? (check all the apply)

a. Entrepreneurship/ownership

b. Placement

c. Exploratory

d. Research/experimentation and analysis

58. What chapter office(s) did you hold in the FFA organization? (check all the apply)

a. President

b. Vice President

c. Secretary

d. Treasurer

e. Reporter

f. Sentinel

g. Parliamentarian

h. Historian

i. Chaplain

j. Jr. Advisor

k. Other (please specify)

1. Other (please specify)

m. Other (please specify)

n. None

59. What state office(s) did you hold in the FFA organization? (check all that apply)

a. President

b. Vice President

c. Secretary

d. Treasurer

e. Reporter

f. Sentinel

g. Parliamentarian

h. Historian

i. Chaplain

j. Other (please specify)

k. Other (please specify)

1. None 
60. What national office did you hold in the FFA organization?
a. President
b. Secretary
c. Regional Vice President
d. None

61. What leadership conferences did you attend as a member? (check all that apply)

a. Chapter leadership conference

b. Regional leadership conference

c. State leadership conference

d. Experiencing Discovery, Growth and Excellence (EDGE)

e. Made for Excellence (MFE)

f. Advanced Leadership Development (ALD)

g. Washington Leadership Conference (WLC)

h. State President's Conference (SPC)

i. National Leadership Conference for State Officers (NLCSO)

j. Building Leaders and Strong Teams of Officers (BlastOFF)

k. Other (please specify)

1. Other (please specify) 
62. Please indicate your highest level of involvement in each Career Development Event area by circling the letter(s) that best corresponds to your response: NA- Not Applicable (Did not participate), C-Chapter, R-Regional, S- State, N-National.

\begin{tabular}{|c|c|c|c|c|c|}
\hline Career Development Event & 艺完 & 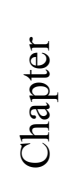 & 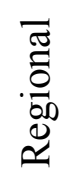 & 莺 & 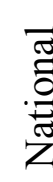 \\
\hline Ag. Communications & NA & $\mathrm{C}$ & $\mathrm{R}$ & $\mathrm{S}$ & $\mathrm{N}$ \\
\hline Ag. Issues & NA & $\mathrm{C}$ & $\mathrm{R}$ & $\mathrm{S}$ & $\mathrm{N}$ \\
\hline Ag. Mechanics & NA & $\mathrm{C}$ & $\mathrm{R}$ & $\mathrm{S}$ & $\mathrm{N}$ \\
\hline Ag. Sales & NA & $\mathrm{C}$ & $\mathrm{R}$ & $\mathrm{S}$ & $\mathrm{N}$ \\
\hline Agronomy & NA & $\mathrm{C}$ & $\mathrm{R}$ & $\mathrm{S}$ & $\mathrm{N}$ \\
\hline Creed Speaking & NA & $\mathrm{C}$ & $\mathrm{R}$ & $\mathrm{S}$ & $\mathrm{N}$ \\
\hline Dairy Cattle & NA & $\mathrm{C}$ & $\mathrm{R}$ & $\mathrm{S}$ & $\mathrm{N}$ \\
\hline Dairy Handlers Activity & NA & $\mathrm{C}$ & $\mathrm{R}$ & $\mathrm{S}$ & $\mathrm{N}$ \\
\hline Dairy Foods & NA & $\mathrm{C}$ & $\mathrm{R}$ & $\mathrm{S}$ & $\mathrm{N}$ \\
\hline Environmental \& Natural Resources & NA & $\mathrm{C}$ & $\mathrm{R}$ & $\mathrm{S}$ & $\mathrm{N}$ \\
\hline Extemporaneous Public Speaking & NA & $\mathrm{C}$ & $\mathrm{R}$ & $\mathrm{S}$ & $\mathrm{N}$ \\
\hline Farm Business Management & NA & $\mathrm{C}$ & $\mathrm{R}$ & $\mathrm{S}$ & $\mathrm{N}$ \\
\hline Floriculture & NA & $\mathrm{C}$ & $\mathrm{R}$ & $\mathrm{S}$ & $\mathrm{N}$ \\
\hline Food Science \& Technology & NA & $\mathrm{C}$ & $\mathrm{R}$ & $\mathrm{S}$ & $\mathrm{N}$ \\
\hline Forestry & NA & $\mathrm{C}$ & $\mathrm{R}$ & $\mathrm{S}$ & $\mathrm{N}$ \\
\hline Horse Evaluation & NA & $\mathrm{C}$ & $\mathrm{R}$ & $\mathrm{S}$ & $\mathrm{N}$ \\
\hline Job Interview & NA & $\mathrm{C}$ & $\mathrm{R}$ & $\mathrm{S}$ & $\mathrm{N}$ \\
\hline Land Judging & NA & $\mathrm{C}$ & $\mathrm{R}$ & $\mathrm{S}$ & $\mathrm{N}$ \\
\hline Livestock Evaluation & NA & $\mathrm{C}$ & $\mathrm{R}$ & $\mathrm{S}$ & $\mathrm{N}$ \\
\hline Marketing Plan & NA & $\mathrm{C}$ & $\mathrm{R}$ & $\mathrm{S}$ & $\mathrm{N}$ \\
\hline Meats Evaluation \& Tech. & NA & $\mathrm{C}$ & $\mathrm{R}$ & $\mathrm{S}$ & $\mathrm{N}$ \\
\hline Nursery/Landscape & NA & $\mathrm{C}$ & $\mathrm{R}$ & $\mathrm{S}$ & $\mathrm{N}$ \\
\hline Parliamentary Procedure & NA & $\mathrm{C}$ & $\mathrm{R}$ & $\mathrm{S}$ & $\mathrm{N}$ \\
\hline Poultry Evaluation & NA & $\mathrm{C}$ & $\mathrm{R}$ & $\mathrm{S}$ & $\mathrm{N}$ \\
\hline Prepared Public Speaking & NA & $\mathrm{C}$ & $\mathrm{R}$ & $\mathrm{S}$ & $\mathrm{N}$ \\
\hline
\end{tabular}


63. Which of the following activities were you involved in as an FFA member? (please check all that apply).

a. Fundraisers

b. Community service projects

c. Fair exhibits

d. State chorus

e. State band

f. National chorus

g. National band

h. Agriscience

i. P.A.L.S.

j. Food for America

k. Risk management essay contest

1. Other (please specify)

m.Other (please specify)

64. Please indicate the highest level of Proficiency award(s) you received as an FFA member.

a. Chapter

b. State

c. National

d. none

65. Were you a member of the 4-H organization?

a. Yes $>$ If yes, continue to question \# 66

b. No $\sum$ If no, skip to question \# 72

66. How many years did you participate in $4-\mathrm{H}$ ?

a. $1-2$

b. $3-4$

c. 5-6

d. $7-8$

e. 9-10

f. 11-12

g. 13 or more

67. Did you have a $4-\mathrm{H}$ project(s)?

a. Yes

If yes, continue to question \# 68

b. No

If no, skip to question \# 69 
68. What best describes your project area(s)? (Please check all that apply)

a. Citizenship and civic education

b. Communication and expressive arts

c. Consumer and family sciences

d. Environmental education and earth sciences

e. Healthy lifestyles education

f. Personal development and leadership

g. Plants and animals

h. Science and technology

69. What club office(s) did you hold in the 4-H organization? (check all the apply)

a. President

b. Vice President

c. Secretary

d. Treasurer

e. Other (please specify)

f. Other (please specify)

g. None

70. What state office(s) did you hold in the 4-H organization? (check all that apply)

a. President

b. Vice President

c. Secretary

d. Treasurer

e. Other (please specify)

f. Other (please specify)

g. None 
71. Which of the following activities were you involved in as a 4-H member? (check all that apply)

a. Camp counselor

b. County camp

c. Other camp (please specify)

d. Other camp (please specify)

e. Other camp (please specify)

f. Junior leader

g. Team leader weekend

h. 4-H advisory council

i. 4-H club leader

j. Fair exhibits

k. Project workshops

1. State judging contests

m. National judging contests

n. Officer's training school

o. National 4-H Congress

p. National 4-H Youth Club Conference

q. Other (please specify)

r. Other (please specify)

s. Other (please specify)

72. What best describes the status of your certification to teach agricultural education?

a. I am certified to teach.

b. I will apply to be certified to teach.

c. I did not/will not apply for certification.

d. I became certified to teach, but I let my certificate expire. 
73. Are you currently teaching agriculture?

a. Yes $\sum$ If yes, skip to question \# 78

b. No

If no, continue to question \# 74

74. Did you ever teach agriculture?

a. Yes

If yes, continue to question \# 75

b. No

\section{If no, skip to question \# 76}

75. What were the five (5) most influential factors that affected your decision to leave agricultural education? (Rank the top five (5) items from the following list in order of importance starting with 1-most influential, 2-second most influential, etc.)

a. Student teaching experience

b. Low salary

c. Time requirements

d. Extended employment

e. Demands of the job

f. Teaching expectations too high

g. Lack of administrative support

h. Unsuccessful as a teacher

i. Too many demands other than teaching

j. Graduate school

k. Other (please specify)

1. Other (please specify)

m. Other (please specify)

Skip to Question \#79 
76. Do you plan to teach agriculture?

a. Yes

If yes, skip to question \#78

b. No

If no, continue to question \#77

77. What were the five (5) most influential factors that affected your decision not to teach agriculture? (Rank the top five (5) items from the following list in order of importance starting with 1-most influential, 2-second most influential, etc.)

a. Low salary

b. Student teaching experience

c. Time requirements

d. Extended employment

e. Graduate school

f. Demands of the job

g. No teaching jobs in area

h. Teaching expectations too high

i. Other (please specify)

j. Other (please specify)

k. Other (please specify)

\section{Skip to question \#79}

78. What were the five (5) most influential factors that affected your decision to teach agriculture? (Rank the top five (5) items from the following list in order of importance starting with 1-most influential, 2-second most influential, etc.)

a. Agricultural background

b. 4-H involvement

c. FFA involvement

d. High school agricultural program involvement

e. My agriculture teacher(s)

f. Other agriculture teachers

g. Friends

h. Family

i. Other people in the agricultural education profession

j. University faculty

k. Involvement in other agricultural organization(s)

1. Other (please specify)

m. Other (please specify) 
79. What best describes your current occupation?

a. Teacher in another content area (please specify)

b. Agricultural business

c. NRCS

d. Extension

e. FSA

f. Undergraduate student

g. Graduate student

h. other (please specify)

80. What is your gender?
a. Male
b. Female

81. What is your age?
a. $20-22$
b. $23-25$
c. $26-28$
d. $29-31$
e. $32-34$
f. 35 or greater

82. What university did you attend while you completed your student teaching experience?

a. Clemson University

b. North Carolina State University

c. The Pennsylvania State University

d. Virginia Polytechnic and State University

e. West Virginia University 


\section{Comments:}

If you have any questions about the survey, please feel free to contact me at: anniehall06@gmail.com or call (304) 293-4832 x 4477

Thank you far taking the time ta camplete this surwey. 
APPENDIX B:

Initial Post Card 
In the next few days you will receive a questionnaire about the factors that influenced your decision regarding the agricultural education profession. Your response is vital to the success of the research as well as recruitment and retention efforts of agricultural education programs in North Carolina, Pennsylvania, South Carolina, Virginia, and West Virginia.

If the agricultural education profession is going to grow and prosper in the $21^{\text {st }}$ century, it must have an adequate supply of qualified teachers. Your participation in this survey will help agricultural education programs take the steps necessary to reach this goal.

If you have any questions, please contact me at:

\section{Annie Hall}

Agricultural and Extension Education

Davis College of Agriculture, Forestry, and Consumer Sciences

West Virginia University

2048 Agricultural Sciences Building

P.O. Box 6108

Morgantown, WV 26506

304-293-4832 ext. 4477

anniehal106@gmail.com 
APPENDIX C:

Cover Letter 
March 15, 2007

Dear Agricultural and Extension Education Graduate:

The student teaching experience has been identified by many as the most important component of the preservice teacher education program. As an undergraduate student in Agricultural and Extension Education, I was faced with the important decision of where to student teach, knowing that choice could impact my decision to become an agricultural education teacher. What effect does the student teacher experience have on an individual's decision to enter the profession? What other factors influence an individual's decision to teach agriculture?

The purpose of this study was to determine the factors that influence an individual's decision to teach agricultural education. By determining how these factors affect an individual's employment decisions, modifications could be made to the student teaching site selection process to enhance the student teaching experience in order to increase the number of students who will become agriculture teachers. Findings of this study will provide universities, teacher educators, and other agricultural education professionals with information to aid the recruitment and retention of individuals who will enter the teaching profession in agricultural education. The results from this study will be used to prepare a thesis to partially fulfill the requirements for a Master of Science Degree in Agricultural and Extension Education.

Participation in this study is completely voluntary and all information you provide will be held as confidential as possible. Your response to this survey will be critical to the success of the study. You may skip any question you are not comfortable answering. You will notice a code at the top left of the return envelope. This code will be used to identify non-respondents for follow-up and will be destroyed before the data are analyzed. Survey results will be reported in a summary format and individual responses will not be identifiable.

Place the completed questionnaire in the enclosed postage-paid self-addressed return envelope and drop it in the mail. Please return your completed questionnaire before March 31, 2007. Thank you for your assistance with this research effort. We sincerely appreciate your time and eagerly await your input.

Sincerely,

Annie Hall

Graduate Student
Harry N. Boone, Jr. Associate Professor 
APPENDIX D:

First Follow-Up Postcard 
On March 15, 2007, I sent you a questionnaire about factors that influenced your decision about a career in agricultural education. As of today, I have not received your reply.

Your responses are vital to the success of this project, so please take the time to complete and return it. If you have already returned the first survey, thank you for your contribution to my research.

If you have any questions, please contact me at:

\section{Annie Hall}

Agricultural and Extension Education

Davis College of Agriculture, Forestry, and Consumer Sciences

West Virginia University

2048 Agricultural Sciences Building

P.O. Box 6108

Morgantown, WV 26506

304-293-4832 ext. 4477

anniehall06@gmail.com 
APPENDIX E:

Follow-Up Cover Letter 
April 5, 2007

Dear Agricultural and Extension Education Graduate:

On March 15, 2007, we sent you a questionnaire about factors that influenced your decision about a career in agricultural education. As of today, we have not received your reply. Your responses are vital to the success of this project, so we have enclosed a second copy of the survey and hope that you will take the time to complete and return it. If you have already returned the first survey, there is no need to complete this one.

The student teaching experience has been identified by many as the most important component of the preservice teacher education program. As an undergraduate student in Agricultural and Extension Education, I was faced with the important decision of where to student teach, knowing that choice could impact my decision to become an agricultural education teacher. What effect does the student teacher experience have on an individual's decision to enter the profession? What other factors influence an individual's decision to teach agriculture?

The purpose of this study was to determine the factors that influence an individual's decision to teach agricultural education. By determining how these factors affect an individual's employment decisions, modifications could be made to the student teaching site selection process to enhance the student teaching experience in order to increase the number of students who will become agriculture teachers. Findings of this study will provide universities, teacher educators, and other agricultural education professionals with information to aid the recruitment and retention of individuals who will enter the teaching profession in agricultural education. The results from this study will be used to prepare a thesis to partially fulfill the requirements for a Master of Science Degree in Agricultural and Extension Education.

Participation in this study is completely voluntary and all information you provide will be held as confidential as possible. Your response to this survey will be critical to the success of the study. You may skip any question you are not comfortable answering. You will notice a code at the top left of the return envelope. This code will be used to identify non-respondents for follow-up and will be destroyed before the data are analyzed. Survey results will be reported in a summary format and individual responses will not be identifiable.

Place the completed questionnaire in the enclosed postage-paid self-addressed return envelope and drop it in the mail. Please return your completed questionnaire before April 20, 2007. Thank you for your assistance with this research effort. We sincerely appreciate your time and eagerly await your input.

Sincerely,

Annie Hall

Graduate Student
Harry N. Boone, Jr.

Associate Professor 
APPENDIX F:

Final Follow-Up Postcard 
On April 2, 2007, I sent you a questionnaire about factors that influenced your decision about a career in agricultural education. As of today, I have not received your reply. Your responses are vital to the success of this project, so I have hope that you will take the time to complete and return it. If you have already returned the survey, disregard this reminder. Thank you for your contribution to my study.

If you have any questions, please contact me at:

\section{Annie Hall}

Agricultural and Extension Education

Davis College of Agriculture, Forestry, and Consumer Sciences

West Virginia University

2048 Agricultural Sciences Building

P.O. Box 6108

Morgantown, WV 26506

304-293-4832 ext. 4477

anniehal106@gmail.com 
APPENDIX G:

Respondent Comments 
I would love to see what you found out by doing this survey. Also, my student teaching experience was awful $\mathrm{b} / \mathrm{c}$ of the teachers non-discipline attitude. I am currently teaching @ high school level and enjoy it. I graduated from my masters in 2002 and I'm just now teaching in 2006-07. I do credit it to my student teaching experience \& community politics. Good luck w/ your survey.

I actually started in Pre-Veterinary Science, but after 1 semester, I realized I would much rather be a teacher, but I knew I still wanted to be in agriculture in some way. So, agricultural education seemed like the perfect fit.....and it was. I love it!

The selection of my site for student teaching was influenced by the fact that I was a graduate student with a graduate assistantship. I need to be close to the University to perform my other duties. I also was not a resident of the state and had no program to go "home" to. I was limited in this way as to the type of school I would be placed in.

I did not join FFA until in college. My high school did not have an agricultural education program.

I would have been more likely to go back to teaching from extension $\underline{\text { F }}$ the State FFA office would have maintained communication with me on the future opening throughout the state.

Even though I drove 45 minutes everyday for student teaching-I loved every minute of it. Our ag. program at the high school has a great bunch of students who really helped influence me to want to teach agriculture!

I just wanted to let you know that this questionnaire was a great idea. The whole college experience was great while I furthered my education as a in Agricultural Education. I learned such a broad range of Agriculture. For me, I know that I have an awesome degree that can always be there if I need it. While having Agriculture in my blood, unfortunately the family business is the path I have to take. Keep up the good work of trying to make programs better.

Good luck on your thesis research! I did research @ the let me know if you need further assistance. for my masters-please

Student teaching is very beneficial.

My student teaching experience questions were answered about my assigned teacher from the university level. The other person at the high school was much more supportive of me as a teacher. Question $78 \& 79$ are out of order $\&$ is confusing to answer if you are currently reaching. This should be changed in future instruments.

Dear Annie,

I am not sure that my survey will help with your research due to the fact that my situation was very unique; you may even want to totally disregard my survey response. 
I went back to school at age 48 and my main purpose was to get a 4- year degree related to agriculture, horticulture, agronomy, etc. I had worked for the for 20 years, but only had a 2-year Turfgrass Degree. I wanted a 4-year degree in order to get a better job for my last 10 years of working for the state. I chose Agricultural Education for 2 main reasons. First, I could graduate sooner due to the fact that the math and chemistry requirements were less than for other degree, and secondly a teaching certification would guarantee that I could go back to work with the state. Teaching agriculture was my back up plan; and Agricultural Education Degree was the best fit for my situation and goals.

Good luck with your study.

My student teaching experience was both good and bad. My cooperating teacher was a friend \& we had some issues due to that. The other cooperating teacher was extremely helpful with questions that were left unanswered by my cooperating teacher. My teaching experiences have not been that great. My $1^{\text {st }}$ school was a middle school. The $1^{\text {st }}$ year was rough as far as FFA participation was concerned but the $2^{\text {nd }}$ year saw a huge increase! My $2^{\text {nd }}$ school was in the city $\&$ my students had no desire or concern for agriculture. I'm also bad at classroom management $\&$ this along with some other issues lead me to quit teaching at the end of the first semester. I may one day return to teaching if better (more rural, ag. Based) school options come available \& I get a little older \& tougher. Thanks!

I loved student teaching \& teaching now! Good Luck!

I was very fortunate to have the agriculture teacher I has as well as the wonderful student teaching experience and university support. Without those 3 things I am not sure I would have the confidence and desire to overcome the difficulties of being a first year teacher.

124

There have been times when I was exploring other occupations while teaching. The reasons I get frustrated with teaching and think about leaving teaching are:

- Too many new laws and regulations in education that seem to make your job impossible

- Requirements to keep certification and time to get them finished

- Student attitude toward school in general

- Too many students and classes for 1 teacher

- Funding for the program to get what is needed

- Constantly seem to be worrying about even having agriculture in the future. Schools are always looking to cut.

Sometimes even having one student succeed in something is rewarding enough to forget about the negatives.

I would not attend the support staff is NOT helpful.

Good luck with your Master's Degree 
I was overall disappointed w/my student teaching placement and decided no to teach $\mathrm{b} / \mathrm{c}$ of it. However, I was sought out $\mathrm{b} / \mathrm{c}$ of a shortage of Ag. teachers and did take the job. I do like my job and am glad to be teaching! My student teaching placement had little FFA involvement but that stemmed from a poor relationship between the 2 ag teachers in that department. There was a huge push to have every detail planned too, but that is not realistic!

I got into college as an AGED student and after my sophomore year thought a lot about changing majors. Then I started to enjoy classes and student teaching is actually what pushed me to love teaching.

I think there should be more planning involved in choosing cooperating sites.

Prospective student teachers should have to visit prospective cooperating centers the year prior to student teaching. Student teachers should also be informed of each prospective cooperating teacher's course load so they can be better prepared!

Also, I have a student teacher who doesn't want to teach afterward and is just completing requirements and that sucks. High school students can pick up on that like sharks drawn to blood.

Also, university supervisors should be required to make one surprise visit so it isn't always a "dog and pony" show when they arrive.

Good luck finishing your project!

Best of luck! Straight forward survey -- I liked that! I entered ag. Education because of the friendly college faculty, the drive to help agriculture, and the change to make school fun in a SOL driven society here in

I had two different student teaching experiences. The first was at a high school. I had 5 different prep. periods each day. Several of them were in things I had never taken a class in. Student teaching here was one of the most exhausting and overwhelming experiences I had ever had in my life. By 5 weeks in my university supervisor and supervising teacher asked me to leave. I was not able to manage my students. I was not able to plan for al these classes. The learning curve was too steep. I was then given a different university supervisor and changed to a middle school. I was able to finish my student teaching and graduate. All of my answers are about my first student teaching experience. My second student teaching experience was much more positive. I felt able to teach students with less knowledge and that were younger.

As a second year teacher I con honestly say that I really enjoy my job and am able to because I have created enough materials for class and a better plan for classroom management. I would have appreciated some type of $1^{\text {st }}$ year teacher support program. The $1^{\text {st }}$ year is difficult for a number of reasons so an outreach program for all $1^{\text {st }}$ year teachers would help $\mathrm{w} /$ resources, management ideas, and just to share experiences and know you're not alone in it all! I was ultimately placed in a student teaching location I did not want as my first choice teacher was out on maternity leave. I had to have a close location because of financial reasons. I enjoyed teaching, but did not feel my cooperating 
teacher taught me much. His heart was in the right place, but I learned more of what not to do from him and asked other area teachers for help. Good luck w/ the research.

Good luck with your grad work Annie! If you need help with anything let me know.

I didn't really know enough about any of the Ag Teachers in to have much of a preference on who I wanted to do my student teaching with. Overall, I would say that my experience was positive. However, I do wish that my cooperating teacher was more involved in activities outside of the classroom. I ended up doing SAE visits by myself and found that the majority of the students didn't have or want to have SAEs. SAEs weren't something that had been required before, so trying to encourage the students to start one was a bit difficult.

As an NRCS employee, I teach agriculture every day though not in the format you and some other University professors realize. I assist adults instead of middle school or high school students, but I assure you, the contents \& techniques are the same for the most part. I also have multiple opportunities to teach to a wide number of organizations \& age groups such as the Master Gardners, 4-H clubs \& the 4-H Leaders Association. I did not enjoy my student teaching at all for a couple of reasons. First, my cooperating teacher had never had a student teacher before me. He was unable to give up control of his seniors \& freshmen leaving me with the two years he thought he could "get back" the way he wanted them once I was gone. He \& my university supervisor could not get over the fact I wanted to work for NRCS instead of "teach agriculture." I got a lower grade in student teaching because I didn't want to teach in the conventional way \& they couldn't stand to give someone an A when they weren't going to "teach." This lowered my overall GPA \& kept me out of an overall A GPA \& out of an honorary fraternity. Yes, I'm bitter. I don't recommend student teaching to many people \& it's put a bad cloud around my memories of college $\&$ the professors that were supposed to help me. They did me a huge disservice. Thanks for asking.

I did work as a 4-H Camp Counselor one summer in Abingdon, VA.

I did not know what I wanted to do when I got out of school. The student teaching helped me in front of groups \& grow as a person. Also, I believe that most All jobs involve education of some degree. Ag Ed. Helped me with my $1^{\text {st }}$ job in sales for Pennington Seed \& it continues to help.

I believe experience through FFA, 4-H, and other farming experiences plays a vital role in aiding toward finding activities to get student involved and educated. My student teaching experience found me without ideas, let alone, enough knowledge or time to learn about subjects to be taught. I felt that the University Supervisor (US) and cooperating teacher expected me to just take over and teach as if I had been a teacher earlier in life. I felt expectations were held too high that I could not accomplish without more help from the cooperating teacher, and university supervisor did not present a positive outlook on my capabilities but made me not want to work harder. The US I felt, did not understand me (personality wise) to where student teacher was new to me, I was 
always nervous, and working all night and day on lesson plans is not good for health and confidence. The atmosphere was negative whenever he/she (US) was around and I believe the US's need to further evaluate capabilities of student teachers prior to student teaching and know where the ST is coming from before making judgments and mockery of their teaching. Also, the University, College, whoever responsible to setting up student teaching sties, needs to contact all involved, County DOE, principal, and teachers prior to ST coming to school. I was rudely welcomed by the principal at my school, insulted, and threatened to be cancelled from student teaching their due to the University not contacting him/her. Principals like that is another reason for me not to teach.

Sorry it was late. As far as some of the site selection questions my main reason in picking the school I did was there were really no other good schools available. I was late in choosing.

Many of the questions involving my coop teacher were n/a.

Sent me a copy of results

Since my first teaching assignment, I have felt extremely insecure in my teaching career. I received very little administrative support while at the high school. In fact, several teachers had taken the position and resigned before I took the position. The mistake I made was not asking people as to the status of the program at the high school. I took the position because I was close to home and because I graduated from the high school. I was sure I could make a difference; I was wrong. I resigned in the middle of the year. I later took another position at a different high school, but my insecurities led to my not renewing my contract. My fellow teachers indicated that I was going a great job but I did not think so. Coupled with me need to explore other careers and my insecurities, I did not renew my contact. Now, my license is almost expired and I really will not be remised if it does expire. Several programs have tried to rehire me, but I just don't think that I can teach again. I just don't know.

Someone who could not make a difference.

This survey did not have adequate questions for the topic area.

My student teaching experience was very good. However, I could not commit to what I think a ag teacher should commit to. Because of this I have taken another job and am much happier and have greater freedom. 
VITA

Lee Ann Hall

May 2002

October 2003

July 2004-July 2005

August 2004-December 2005

August-December 2005

February-April 2006

May 2006

August 2006-May 2007

August 2007
Graduated - Tyler Consolidated High School

Sistersville, WV 26175

Earned American FFA Degree

NW Region Vice President

West Virginia FFA Association

Undergraduate Teaching Assistant

AGEE 421-Agricultural Communications

West Virginia University

Morgantown, WV 26506

Undergraduate Teaching Assistant FDSC 367-Muscle Foods Technology

West Virginia University

Morgantown, WV 26506

Student Teacher

Taylor County Technical Center

Grafton, WV 26354

Bachelor of Science in Agriculture

Agricultural and Environmental Education

West Virginia University

Morgantown, WV 26506

Graduate Teaching Assistant

AGEE 101-Global Food \& Agriculture Industry

West Virginia University

Morgantown, WV 26506

Master of Science

Agricultural and Extension Education

West Virginia University

Morgantown, WV 26506 